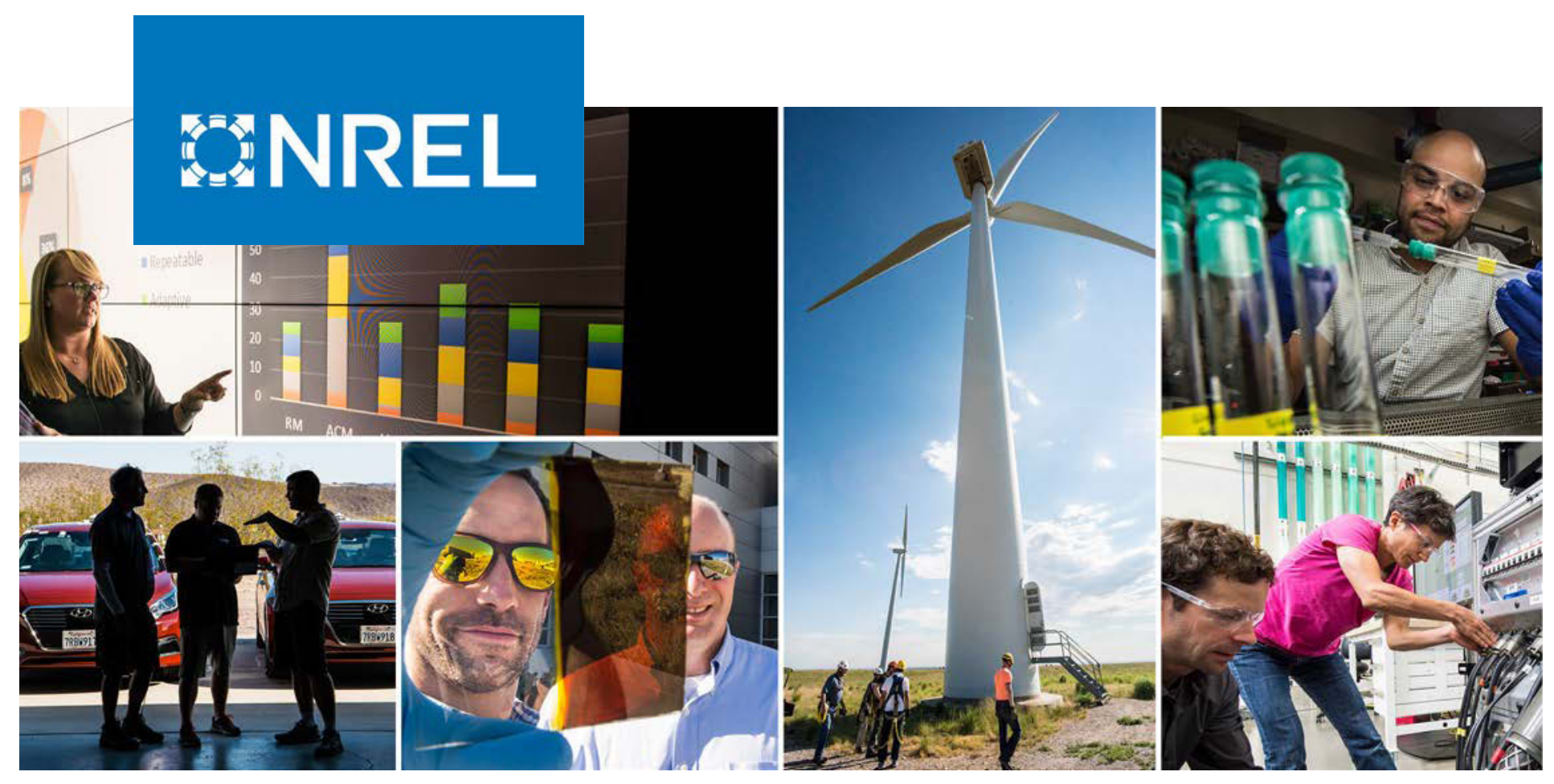

\title{
Laboratory Wind Turbine Blade Static Testing of the Sandia National Rotor Testbed 13-Meter Wind Turbine Blade
}

Bill Gage, Ryan Beach, and Scott Hughes

National Renewable Energy Laboratory

NREL is a national laboratory of the U.S. Department of Energy

Office of Energy Efficiency \& Renewable Energy

Operated by the Alliance for Sustainable Energy, LLC

This report is available at no cost from the National Renewable Energy Laboratory (NREL) at www.nrel.gov/publications.
Technical Report

NREL/TP-5000-79416

September 2021 


\title{
FNREL
}

\section{Laboratory Wind Turbine Blade Static Testing of the Sandia National Rotor Testbed 13-Meter Wind Turbine Blade}

\author{
Bill Gage, Ryan Beach, and Scott Hughes
}

National Renewable Energy Laboratory

\section{Suggested Citation}

Gage, Bill, Ryan Beach, and Scott Hughes. 2021. Laboratory Wind Turbine Blade Static Testing of the Sandia National Rotor Testbed 13-Meter Wind Turbine Blade. Golden, CO: National Renewable Energy Laboratory. NREL/TP-5000-79416.

https://www.nrel.gov/docs/fy21osti/79416.pdf.

NREL is a national laboratory of the U.S. Department of Energy Office of Energy Efficiency \& Renewable Energy Operated by the Alliance for Sustainable Energy, LLC

This report is available at no cost from the National Renewable Energy Laboratory (NREL) at www.nrel.gov/publications.

Contract No. DE-AC36-08GO28308
Technical Report

NREL/TP-5000-79416

September 2021

National Renewable Energy Laboratory 15013 Denver West Parkway Golden, CO 80401 303-275-3000 • www.nrel.gov 


\section{NOTICE}

This work was authored by the National Renewable Energy Laboratory, operated by Alliance for Sustainable Energy, LLC, for the U.S. Department of Energy (DOE) under Contract No. DE-AC36-08GO28308. Funding provided by the U.S. Department of Energy Office of Energy Efficiency and Renewable Energy Wind Energy Technologies Office. The views expressed herein do not necessarily represent the views of the DOE or the U.S. Government.

This report is available at no cost from the National Renewable Energy Laboratory (NREL) at www.nrel.gov/publications.

U.S. Department of Energy (DOE) reports produced after 1991 and a growing number of pre-1991 documents are available free via www.OSTI.gov.

Cover Photos by Dennis Schroeder: (clockwise, left to right) NREL 51934, NREL 45897, NREL 42160, NREL 45891, NREL 48097, NREL 46526.

NREL prints on paper that contains recycled content. 


\title{
BLADE STATIC TEST REPORT \\ Test Identifier: SNL_2017
}

\section{LABORATORY WIND TURBINE BLADE STATIC TESTING OF THE SANDIA NATIONAL ROTOR TESTBED 13-METER WIND TURBINE BLADE \\ Maximum Flapwise Proof Loading \\ Minimum Flapwise Proof Loading \\ Maximum Edgewise Proof Loading \\ Minimum Edgewise Proof Loading \\ Flapwise Fatigue Loading \\ Ultimate Positive Flapwise Static Load}

\author{
Conducted by: \\ National Renewable Energy Laboratory \\ National Wind Technology Center \\ 15013 Denver West Parkway \\ Golden, CO 80401 \\ Conducted for: \\ Sandia National Laboratories \\ P.O. Box 5800 \\ Albuquerque, NM 87185
}

22 AUGUST 2018

APPROVAL BY

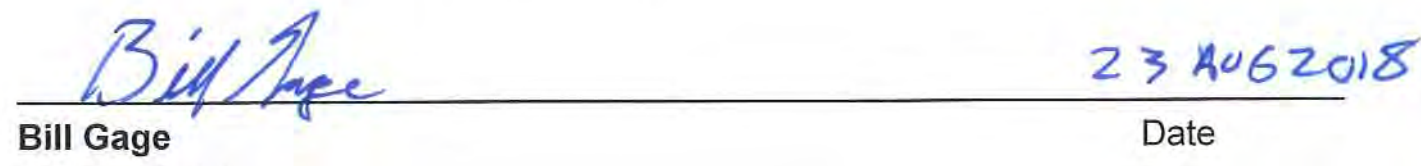

Test Technician

APPROVAL BY

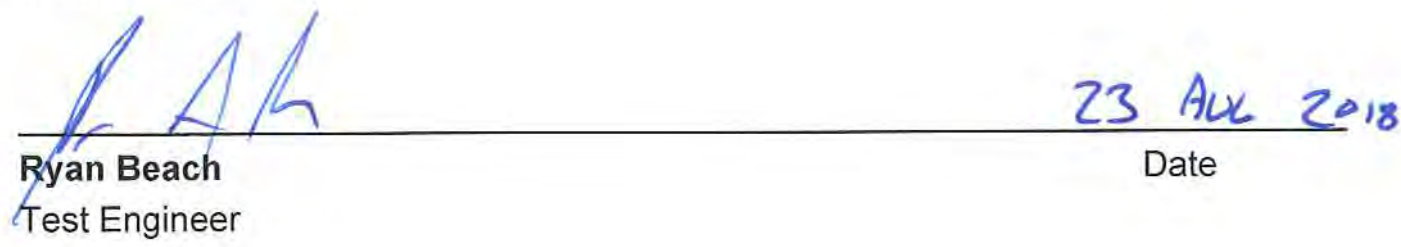

APPROVAL BY

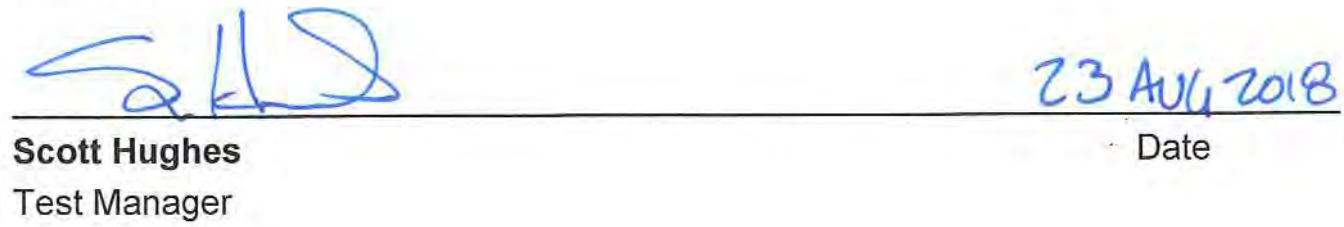




\section{TABLE OF CONTENTS}

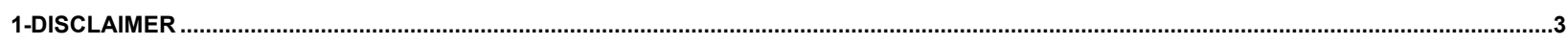

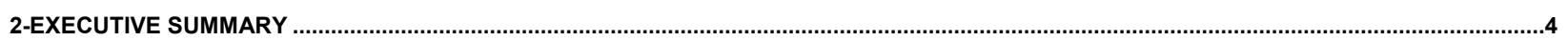

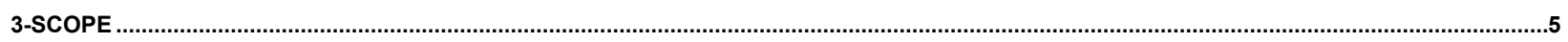

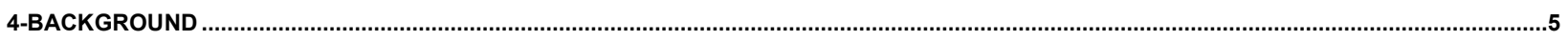

5-TEST OBJECTIVE

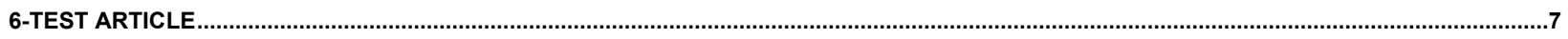

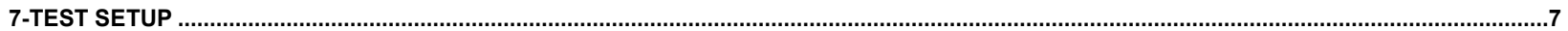

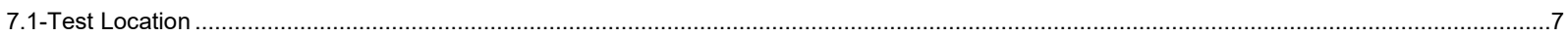

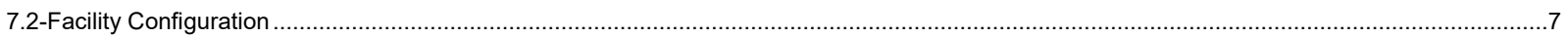

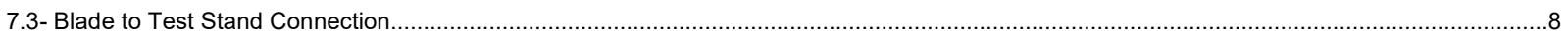

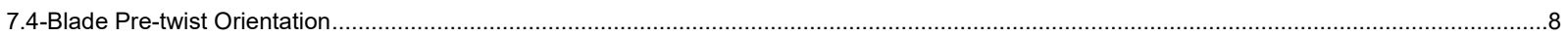

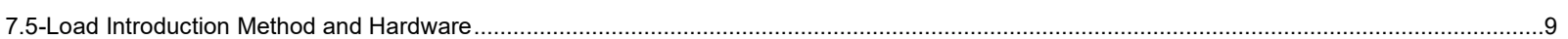

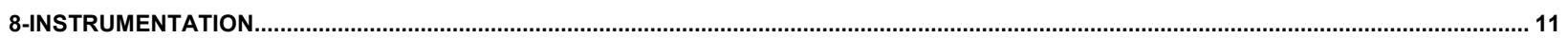

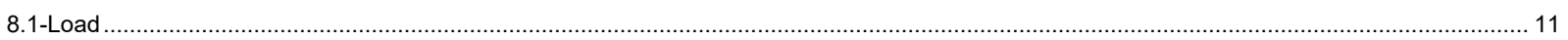

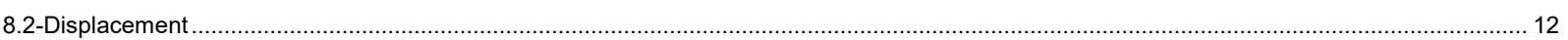

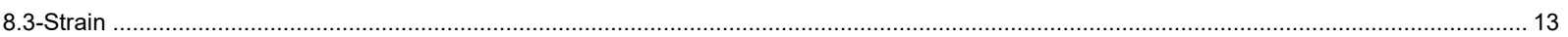

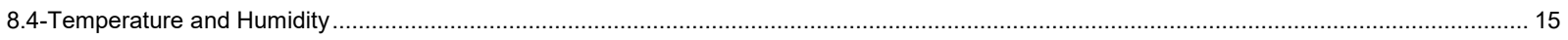

8.5-Accelerometers .

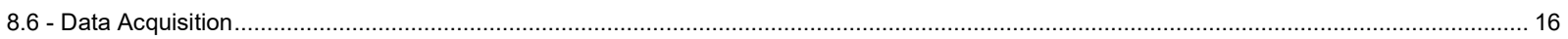

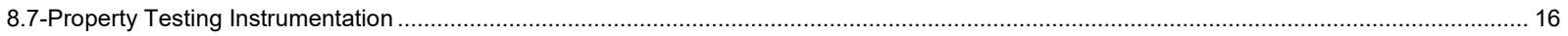

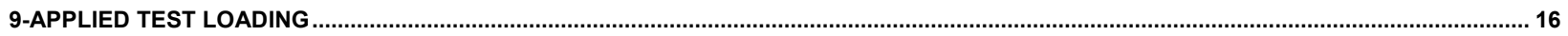

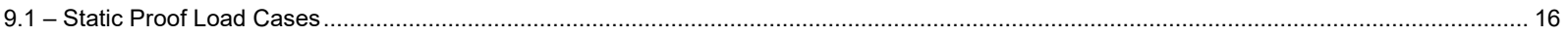

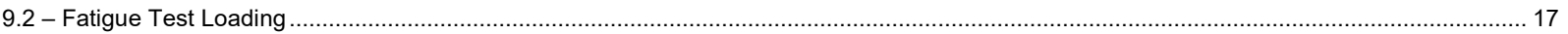

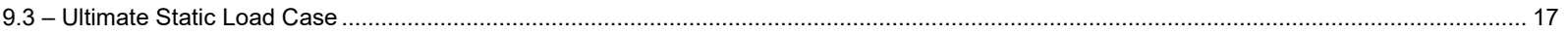

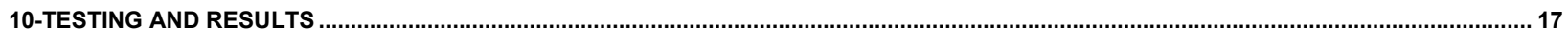

10.1-Property Testing

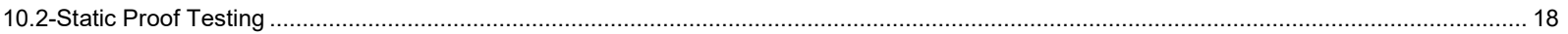

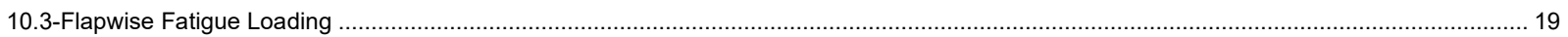

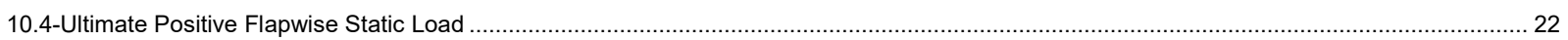

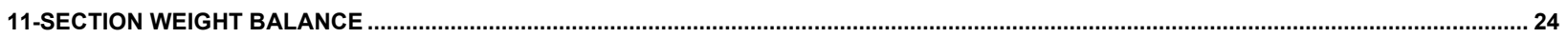

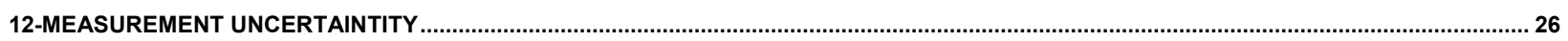

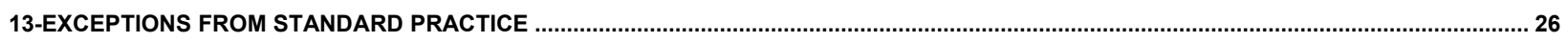

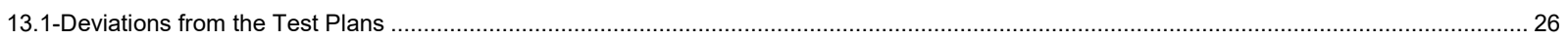

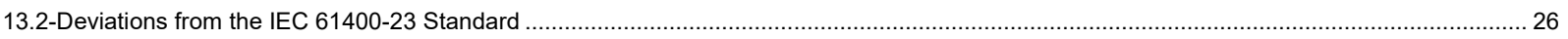

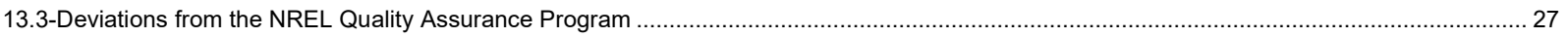

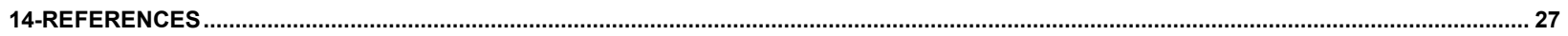

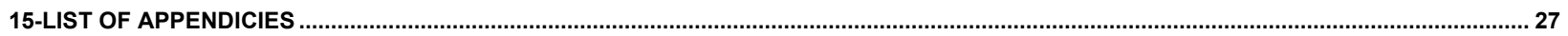

APPENDIX A- Applied Test Moment Calculation for Static Proof Load Cases …….................................................................................... 28

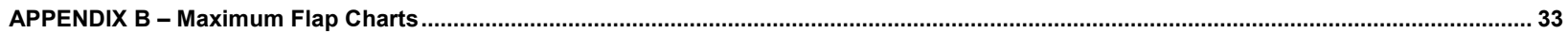

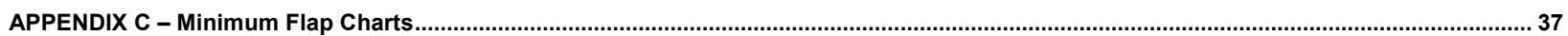

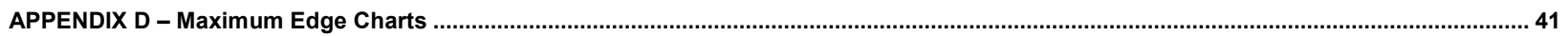

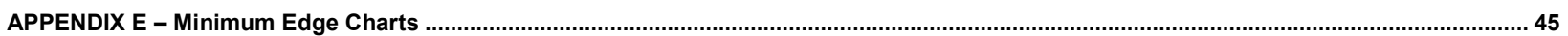

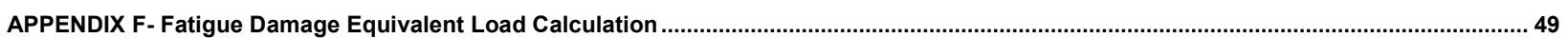

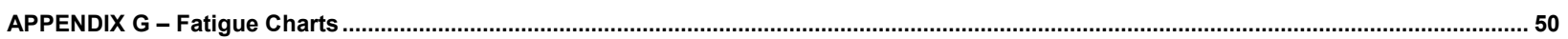

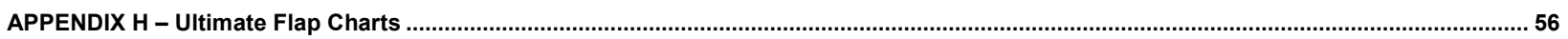

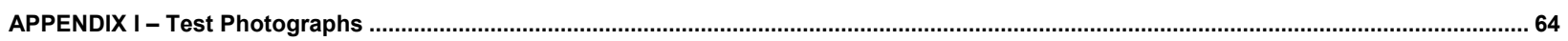

SNL_2017 - Sandia NRT Blade-0 Laboratory Structural Test Report $\quad$ Page 2 of 85

This report is available at no cost from the National Renewable Energy Laboratory at www.nrel.gov/publications. 
ACROYNMS and INITIALISMS

\begin{tabular}{|l|c|l|c|}
\hline \multicolumn{1}{|c|}{ Phrase } & Abb. & \multicolumn{1}{c|}{ Phrase } & Abb. \\
\hline National Wind Technology Center & NWTC & Department of Energy & DOE \\
\hline National Renewable Energy Laboratory & NREL & National Rotor Testbed & NRT \\
\hline Sandia National Laboratories & SNL & Scaled Wind Farm Technology & SWiFT \\
\hline Ethercat Data Acquisition System & EDAS & Lightning Protection System & LPS \\
\hline National Instruments & NI & Center of Gravity & CG \\
\hline Damage Equivalent Load & DEL & Leading Edge & LE \\
\hline Trailing Edge & TE & High Pressure side & HP \\
\hline Low Pressure side & LP & & \\
\hline
\end{tabular}

\section{1-DISCLAIMER}

This report was prepared by the National Renewable Energy Laboratory (NREL), operated for the United States Department of Energy (DOE) by the Alliance for Sustainable Energy, LLC (Alliance), as an account of work sponsored by the United States government. The test results documented in this report define the characteristics of the test article as configured and under the conditions tested.

This report is provided "as is" and neither the government, the Alliance, NREL, nor any of their employees, makes any warranty, express or implied, including the warranties of merchantability and fitness for a particular purpose, or assumes any legal liability or responsibility for the accuracy, completeness, or usefulness of any such information disclosed in the report, or of any apparatus, product, or process disclosed or represents that its use would not infringe privately owned rights.

Neither Alliance nor the U. S. Government shall be liable for special, consequential or incidental damages. Reference herein to any specific commercial product, process, or service by trade name, trademark, manufacturer, or otherwise does not necessarily constitute or imply its endorsement, recommendation, or favoring by the United States government or any agency thereof. The views and opinions of the authors expressed herein do not necessarily state or reflect those of the United States government or any agency thereof or Alliance.

NREL is a DOE Laboratory, and as an adjunct of the United States government, cannot certify wind turbines. The information in this report is limited to NREL's knowledge and understanding as of this date.

NREL is accredited by the American Association for Laboratory Accreditation (A2LA) and the results shown in this test report have been determined in accordance with the NREL's terms of accreditation unless stated otherwise in the report. 
This report shall not be reproduced, except in full, without the written approval of Alliance or successor operator of NREL.

Results presented in this report are for the NRT Blade 0 tested at NREL. Data used to calculate the applied test moment is based on model information provided by Sandia.

\section{2-EXECUTIVE SUMMARY}

The Sandia National Laboratories (SNL or Sandia) National Rotor Testbed (NRT) blade is a new design for experimental research and development at the Sandia Scaled Wind Farm Technology (SWiFT) facility, located at Texas Tech University's National Wind Institute Research Center in Lubbock, TX. Four NRT blades were manufactured, with three blades for operation at the SWiFT facility, and one blade intended for structural validation. A series of structural validation tests including property testing, static strength testing, and fatigue testing were performed at the National Renewable Energy Laboratory (NREL). This report documents the static and fatigue load cases applied to the NRT blade.

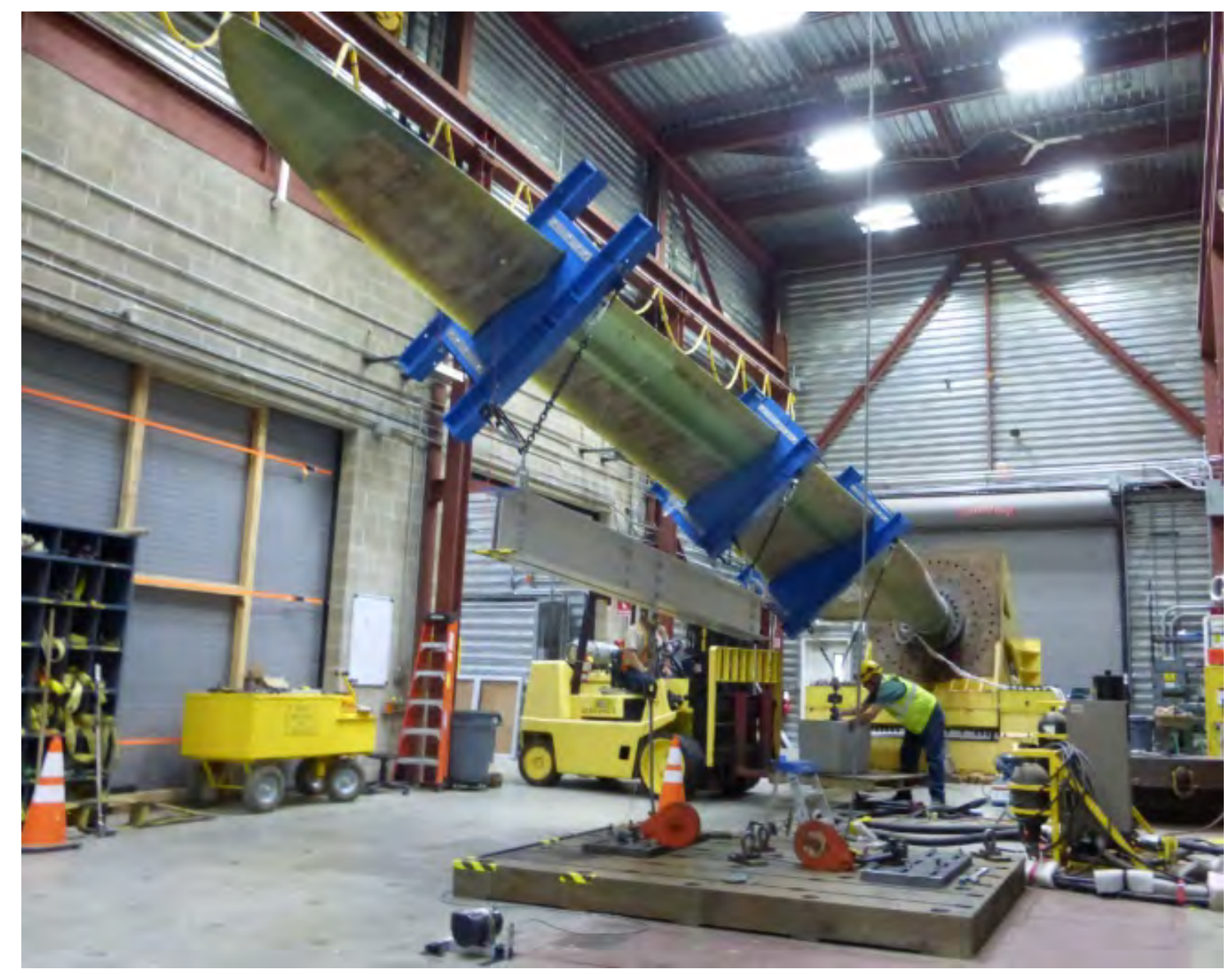

Figure 2.1 - Minimum Edgewise Static Test Setup 


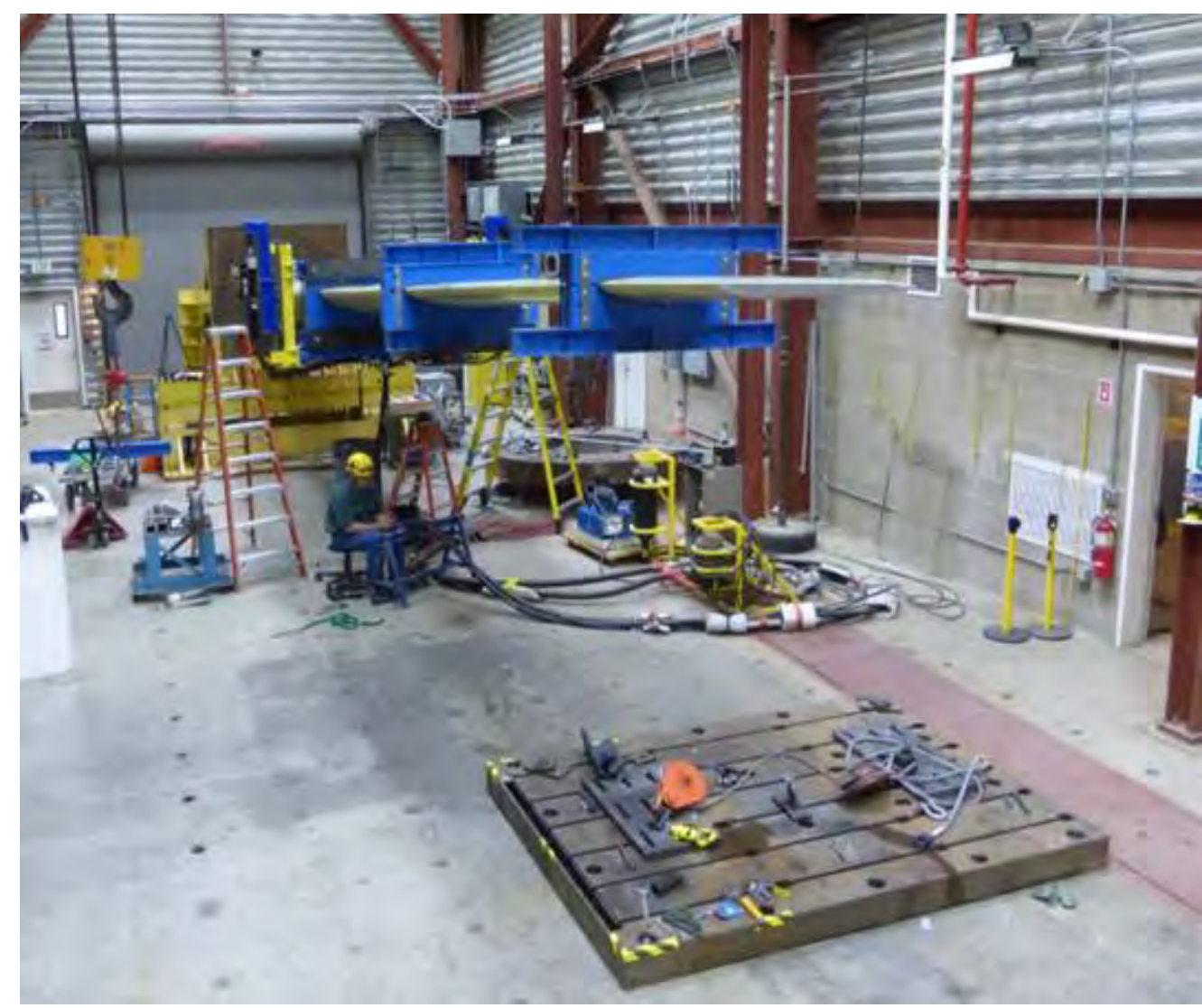

Figure 2.2. Fatigue Test Setup

\section{3-SCOPE}

This test report provides information on the test setup, instrumentation, and load matrix used for laboratory testing of the NRT blade. This report covers the following load cases:

- Maximum Flapwise Proof Load

- Minimum Flapwise Proof Load

- Maximum Edgewise Proof Load

- Minimum Edgewise Proof Load

- Flapwise Fatigue Load

- Ultimate Positive Flapwise Static Load

\section{4-BACKGROUND}

Static and fatigue laboratory test loading was performed on the Sandia NRT blade. Prior to static testing, property testing including airfoil profiling and a modal survey was performed. Following the static proof loading described in this report a flapwise fatigue test was performed 
then followed by an ultimate static test to failure. Table 4.1 provides information and references on each of the experiments and tests performed on the blade.

Table 4.1. Sequence of Property and Structural Testing of the Sandia NRT Blade at NREL

\begin{tabular}{|l|l|l|}
\hline \multicolumn{1}{|c|}{ Test } & \multicolumn{1}{c|}{ Test Periods } & \multicolumn{1}{c|}{ Reference } \\
\hline Blade Delivery & January 2017 & n/a \\
\hline Airfoil profiling & May and June 2017 & {$[1]$} \\
\hline Modal Survey & April, May, June 2017 & {$[2]$} \\
\hline Static Proof Load Testing & July 2017 - September 2017 & This report \\
\hline Flapwise Fatigue Testing & December 2017 - January 2018 & This report \\
\hline Ultimate Static Test & January 2018 & This report \\
\hline Blade sectioning & May 2018 & {$[3]$} \\
\hline Blade removed from NWTC & June 2018 & n/a \\
\hline
\end{tabular}

Work was performed through an inter-agency agreement between Sandia and NREL [4]. DOE program funds were used for the edgewise static load cases as part of the wake dynamics project. NREL subtask WUJJ1000 was used for the inter-agency agreement, and NREL subtask WE163D01 was used for program support.

Testing was performed according to NREL's Quality Assurance Program. NREL is accredited by A2LA for blade testing in accordance with the IEC 61400-23 standard [5], A2LA Certificate Number 1239-01 [6]. Testing operations complied with the NWTC Structural Testing Safe Operating Procedure and were conducted within the scope of the Job Walk [7]. Structural validation testing was performed according to the test plans for static and fatigue testing $[8,9$, $10,11]$.

\section{5-TEST OBJECTIVE}

The objectives of the static proof loading of the blade were to:

1. Validate the blade can sustain the factored extreme negative flapwise bending and static edgewise bending moments.

2. Measure deflections and strains resulting from the applied test loads.

The objectives of the flapwise fatigue were to:

1. Apply a cyclic fatigue load to the blade to an equivalent 20 -year damage equivalent load

2. Measure strains and accelerations during fatigue loading 
The objectives of the ultimate static test were to:

1. Apply a static load to the blade up to a root moment of $380 \mathrm{kN} \mathrm{m}$ (test rig constraint).

2. Measure deflections and strains resulting from the applied test loads. Displacement sensors were removed prior to loading to failure.

\section{6-TEST ARTICLE}

The Sandia NRT blade was $13 \mathrm{~m}$ in length, with construction materials that include fiberglass, balsa wood, and epoxy. The blade root bolt pattern is (30) M20 bolts on a 508-mm bolt pattern. The nominal maximum chord is $1.473 \mathrm{~m}$. The blade includes pre-bend in the flapwise, upwind direction. The blade was not identified with a unique marking but was identified by Sandia as NRT Blade 0.

The blade was fabricated by TPI Composites from an additive manufactured mold designed by Oak Ridge National Laboratory.

The trailing edge was modified at the $9.46 \mathrm{~m}$ and $9.71 \mathrm{~m}$ stations. Small $(4 \mathrm{~mm})$ triangular sections were cut from the blade for material testing because of visible abnormalities noted upon delivery to NREL (caused by the force exerted by tie-down straps during shipping to NREL).

\section{7-TEST SETUP}

\section{1-Test Location}

Testing was performed inside of the highbay of the Structural Testing Laboratory (STL) at NREL's National Wind Technology Center (NWTC).

\section{2-Facility Configuration}

The blade was cantilevered to the $5.4 \mathrm{MN} \mathrm{m}$ test stand in the STL highbay. The $5.4 \mathrm{MN} \mathrm{m}$ test stand was secured to t-slot base plates on the west end of the highbay.

The test stand was tilted back at several angles between load cases to allow adequate clearance for test equipment while keeping the blade relatively close to the laboratory floor. Test stand inclination angles are provided in the test plan.

A T-slot base plate blade was mounted to the highbay floor to react the external load applied by the crane or electric winch for both static load cases and calibration pulls during the fatigue test. 


\section{3- Blade to Test Stand Connection}

The blade was mounted to the test stand through an adapter plate. The adapter plate is a 3" $(\sim 75-\mathrm{mm})$ thick, A-36 steel plate. Bolt torque and mounting configurations are provided in the test plans.

\section{4-Blade Pre-twist Orientation}

For all static load cases the test loads were applied vertically with respect to the laboratory. For each load case the blade and attached adapter plate was removed from the test stand, keeping the blade mounted to the adapter plate. The blade was rotated and remounted to the test stand for each load case.

Figure 7.1 provides the inclination of the $12.96 \mathrm{~m}$ airfoil as mounted to the test stand for each static load case.
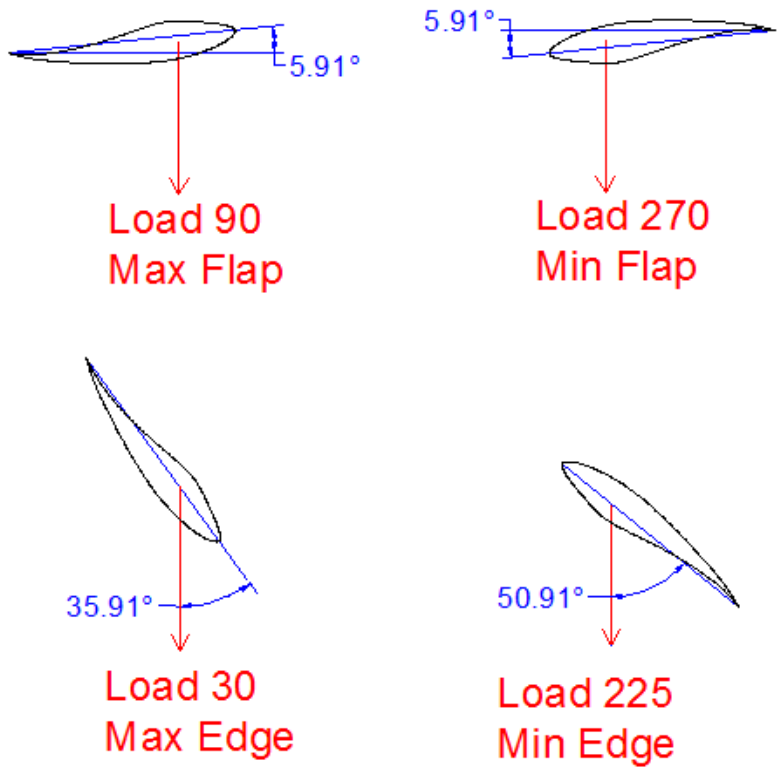

Figure 7.1. Blade Mounting Orientation (view is from root to tip)

The mounting orientation for the flapwise fatigue test and the ultimate positive flapwise (Load 90) was the same as the maximum flapwise proof load, with the inclination of the $12.96 \mathrm{~m}$ airfoil at 5.91 degrees. 


\section{5-Load Introduction Method and Hardware}

\subsection{1 - Static Proof Load Cases}

The applied test bending moment includes blade self-weight, tare load from the weight of the load saddles, and the external loads applied via the overhead crane and ballast weights.

Three load introduction stations at $4.6 \mathrm{~m}, 7.55 \mathrm{~m}$ and $10.85 \mathrm{~m}$ were used to apply external loads. A ballast weight was suspended from the blade at the $4.6 \mathrm{~m}$ station. External test loads were applied at the the $7.55 \mathrm{~m}$ and $10.85 \mathrm{~m}$ stations by a test operator controlling the STL's 35 ton overhead bridge crane. A spreader bar was positioned between the $7.55 \mathrm{~m}$ and $10.85 \mathrm{~m}$ load introduction stations to carry the load applied by the crane to the saddles. Turning blocks mounted to the t-slot base plates reacted and redirected the force from the overhead bridge crane to a force applied to the spreader bar pulling downwards towards the laboratory floor. A 5/8-in Dyneema synthetic rope was used to connect to the spreader bar and run through turning blocks to the overhead crane.

Load saddles were used to apply the external loads to the blade. Load saddles are comprised of wood forms which are shaped to match the airfoil profile; steel frames are built around the wood forms to transfer the test load from the winches to the wood forms. The wood forms are constructed from microlams beams that are cut to the station airfoil profile and fitted to the blade surface with rubber and structural putty, this ensures good surface contact that distributes to point load from the winch across the station chord. The load saddle wood forms were 5.25 in $(133.4 \mathrm{~mm})$ thick in the spanwise direction, centered at the nominal blade station. The steel frames are fabricated around the wood forms and secure the load saddle to the blade using four $1 / 2-13$ grade $B 7$ threaded rods that were torqued to $20 \mathrm{ft}-\mathrm{lbf}$. The torque applied to the threaded rods created a preload of approximately $10.7 \mathrm{kN}$ on the blade. Saddles were designed to apply loads to the blade at the center of a line between the centers of the high-pressure and lowpressure spar caps.

For edge load static cases, chain bridles were attached to the saddles. Unequal length bridles provided the ability to adjust the external load to center through the center of the spar. For all load cases the geometry of the saddle was designed for load to pass through the center of the spar.

\subsection{2 - Fatigue Testing}

For initial fatigue testing, two UREX exciters were mounted to the $4.6 \mathrm{~m}$ saddle. Additional ballast mass was attached to the $4.6 \mathrm{~m}$ and $7.55 \mathrm{~m}$ saddles, while the metal frame of the 10.85 $\mathrm{m}$ station saddle was removed. Saddles were ballasted according to the test plan to provide the appropriate mean load and fatigue load amplitude. The amplitude of the applied moment was controlled by adjusting the displacement amplitude of the UREX actuator(s). 
Early in the fatigue test it was noted that the amplitude ranges of accelerometers and strain gages were not steadily tracking the UREX actuator amplitude. It is thought that the first flap frequency at which the test was operating at was near a subharmonic frequency of the second flap mode, and potentially near a subharmonic of a torsional mode. The north UREX was removed from the blade near cycle 109,400, while additional oscillating mass was added to the UREX. The $10.85 \mathrm{~m}$ saddle weight was reduced by $14-\mathrm{kg}$ to $21-\mathrm{kg}$. The test was noted to run steadily following these modifications. Table 7.2 provides the $4.6 \mathrm{~m}$ saddle mass and total oscillating mass as originally configured and for the modified configuration. Note that these weights are approximate as the saddle was not removed and weighed during this modification.

Table 7.2. Fatigue Test $4.6 \mathrm{~m}$ saddle and UREX Weights

\begin{tabular}{|l|l|l|}
\hline \multicolumn{1}{|c|}{ Property } & \multicolumn{1}{|c|}{$\begin{array}{c}\text { Initial } \\
\text { configuration }\end{array}$} & $\begin{array}{l}\text { After removal of North } \\
\text { UREX at cycle } \mathbf{1 0 9 , 4 0 0}\end{array}$ \\
\hline Total Saddle Mass $[\mathrm{kg}]$ & 1352 & 1197 \\
\hline Total Oscillating mass $[\mathrm{kg}]$ & 225 & 170 \\
\hline Test Operating Frequency $[\mathrm{Hz}]$ & 1.5 & 1.57 \\
\hline
\end{tabular}

The Lightning Protection System (LPS) was observed (heard) to be contacting the inside blade surface during loading near the tip of the blade. A hole was drilled into the high-pressure blade surface at the $12 \mathrm{~m}$ station and then expanding urethane foam was injected to secure the LPS. The amount of foam injected was unmeasured however the weight listed by the foam manufacturer was $0.45 \mathrm{~kg}$.

\subsection{3 - Ultimate Positive Flapwise Static Loading}

The $4.6 \mathrm{~m}$ and $7.55 \mathrm{~m}$ saddles were ballasted for the ultimate flapwise loading. An electric winch applied loads to the $10.85 \mathrm{~m}$ saddle. The winch line ran through a block and tackle system that created a two-part line connecting to the load saddle. This arrangement is shown in Figure 7.2 during the $75 \%$ (of anticipated ultimate) loading, as the load cell is positioned between the saddle and pulley. 


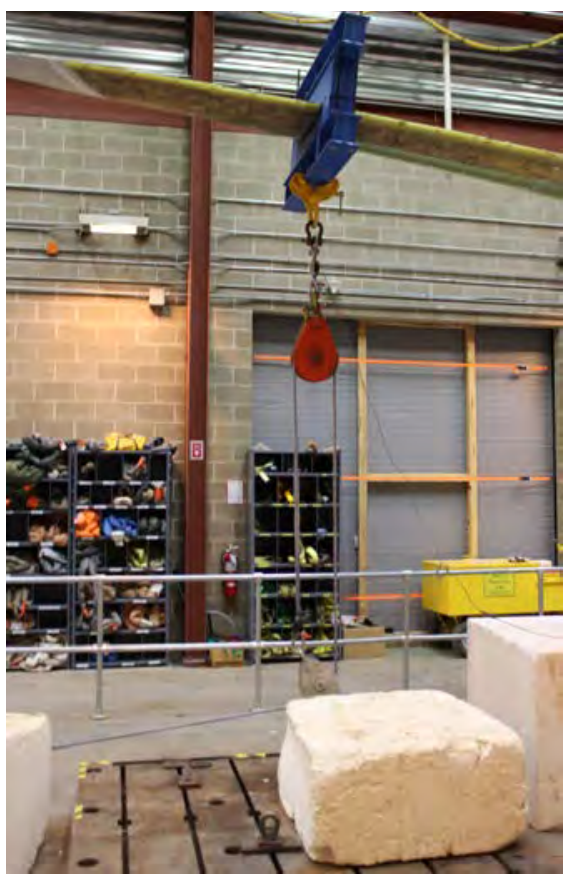

Figure 7.2. Two-part rigging line attached to the $10.85 \mathrm{~m}$ station saddle

\section{8-INSTRUMENTATION}

The channel map for the sensors used during the test is provided in the test plans [8, 9, 10, 11]. Instrumentation records and calibration certificates are available upon request.

\section{1-Load}

\subsection{1 - Static Proof Load}

Two load cells were used to measure the applied test loads during static proof load testing. One load cell was positioned at the $4.6 \mathrm{~m}$ station and the second load cell was positioned under the spreader beam connecting to the $7.55 \mathrm{~m}$ and $10.85 \mathrm{~m}$ station saddles. Table 8.1 provides the specifications for the load cells. Load cells were zeroed without rigging attached beneath the load cell.

Table 8.1. Static Proof Load Cell Specifications

\begin{tabular}{|c|c|c|c|}
\hline Type & Manufacturer & Model & Serial \\
\hline Load Cell 1 & MTS & $661.20 \mathrm{E}-03$ & $04859 \mathrm{C}$ \\
\hline Load Cell 2 & Transducer Techniques & SW-10K & $4718 \mathrm{C}$ \\
\hline
\end{tabular}




\subsection{2 - Fatigue}

A load cell was used for calibration pulls to enable correlation of moment to strain. Table 8.2 provides specifications for the load cell used for moment calibration during fatigue testing.

\section{Table 8.2. Fatigue Calibration Pull Load cell}

\begin{tabular}{|c|c|c|c|}
\hline Type & Manufacturer & Model & Serial \\
\hline Load Cell & Transducer Techniques & SW-10K & $4718 \mathrm{C}$ \\
\hline
\end{tabular}

\subsection{3 - Ultimate Static Load}

A single load cell was connected to the $10.85 \mathrm{~m}$ saddle during ultimate static load testing. During the $75 \%$ (of estimated failure load) load ramp the load cell was connected directly underneath the saddle. For the load ramp to failure, the load cell was moved and positioned ahead of the two-part rigging line connected to the saddle. Since the load cell was measuring the load in the winch line before reeving through the turning blocks to the saddle, creating a twopart line, the applied load at the saddle during the failure pull will be approximately twice the reading of the load cell. However, friction in the turning block bearings will decrease the load applied to the blade compared to load cell readings. Table 8.3 provides information on the load cell used during the ultimate static load test.

Table 8.3. Ultimate Static Test Load Cell Specification

\begin{tabular}{|c|c|c|c|}
\hline Type & Manufacturer & Model & Serial \\
\hline Load Cell & Transducer Techniques & SW-10K & $4718 \mathrm{C}$ \\
\hline
\end{tabular}

\section{2-Displacement}

\subsection{1 - Static Proof Loading}

Three string potentiometers were used to measure blade displacements at the $4 \mathrm{~m}, 7 \mathrm{~m}$, and $11.25 \mathrm{~m}$ stations for static testing. String potentiometers were attached between the blade and the ground along the center of the spar cap. A laser distance transducer was positioned to measure blade displacements near the trailing edge of the $7 \mathrm{~m}$ station. The laser distance transducer was not used for the edgewise static load cases. String pot and laser distance transducer specifications are provided in Table 8.4 . 
Table 8.4. String Potentiometer and Laser Distance Transducer Specifications

\begin{tabular}{|c|c|c|c|}
\hline Type & Manufacturer & Model & Serial \\
\hline String Pot & Unimeasure & HX-PA-30 & 32060220 \\
\hline String Pot & Unimeasure & HX-PA-30 & 32060221 \\
\hline String Pot & Unimeasure & HX-PA-50 & 32060222 \\
\hline String Pot & Unimeasure & HX-PA-80 & 31030644 \\
\hline String Pot & Unimeasure & HX-PA-150 & 32060224 \\
\hline String Pot & Unimeasure & HX-PA-250 & 32060226 \\
\hline LDT & Balluff & DOD 63M-LA04-S115 & 1333 DE \\
\hline
\end{tabular}

\subsection{2 - Fatigue Loading}

For fatigue testing the LDT was positioned at the $1 \mathrm{~m}$ station, facing the low-pressure side of the blade. This was the only displacement transducer used during fatigue cycling. For calibration pulls, the Unimeasure string potentiometer was used (s/n 32060222).

\subsection{3 - Ultimate Positive Flapwise Loading}

Displacement transducers were removed prior to the load ramp to blade failure during ultimate static loading.

\section{3-Strain}

Resistance strain gages were installed on the blade for strain measurement. The single-axis strain gages are Measurements Group WK-06-250BG-350 and the rosettes are Measurements Group WK-06-250RA-350. All the strain gages have a nominal $350 \mathrm{Ohm}$ resistance and were connected in a three-wire configuration. Single-axis strain gages were orientated at 0 degree (parallel with the spanwise axis and perpendicular to the chordwise axis). Rosettes were oriented such that one gage is 0 degrees, one gage is 45 degrees, and one gage is 90 degrees (parallel with the chordwise axis and perpendicular to the spanwise axis). Table 8.5 provides the location of the strain gages.

Table 8.5. Strain Gage Locations

\begin{tabular}{|l|c|c|c|c|}
\hline \multicolumn{1}{|c|}{ Strain Gage Name } & Span & Surface & Chord Position & Type \\
\hline SG01-200-LP0 & 0.2 & LP & $0^{\circ}$ & Uni \\
\hline SG02-200-LP45 & 0.2 & LP & $45^{\circ}$ & Uni \\
\hline SG03-200-LP90 & 0.2 & LP & $90^{\circ}$ & Uni \\
\hline SG04-200-LP135 & 0.2 & LP & $135^{\circ}$ & Uni \\
\hline SG05-200-HP180 & 0.2 & HP & $180^{\circ}$ & Uni \\
\hline SG06-200-HP225 & 0.2 & HP & $225^{\circ}$ & Uni \\
\hline
\end{tabular}




\begin{tabular}{|c|c|c|c|c|}
\hline Strain Gage Name & Span & Surface & Chord Position & Type \\
\hline SG07-200-HP270 & 0.2 & $\mathrm{HP}$ & $270^{\circ}$ & Uni \\
\hline SG08-200-HP315 & 0.2 & HP & $315^{\circ}$ & Uni \\
\hline SG09-1900-HP-AP-0 & 1.9 & HP & Aft Panel at Spar Interface & Rosette \\
\hline SG10-1900-HP-AP-45 & 1.9 & $\mathrm{HP}$ & Aft Panel at Spar Interface & Rosette \\
\hline SG11-1900-HP-AP-90 & 1.9 & $\mathrm{HP}$ & Aft Panel at Spar Interface & Rosette \\
\hline SG12-2500-HP-AP-0 & 2.5 & HP & Aft Panel at Spar Interface & Rosette \\
\hline SG13-2500-HP-AP-45 & 2.5 & HP & Aft Panel at Spar Interface & Rosette \\
\hline SG14-2500-HP-AP-90 & 2.5 & HP & Aft Panel at Spar Interface & Rosette \\
\hline SG15-2750-HP-TE & 2.75 & $\mathrm{HP}$ & $\mathrm{TE}$ & Uni \\
\hline SG16-2750-LP-TE & 2.75 & LP & $\mathrm{TE}$ & Uni \\
\hline SG17-2900-LP-SC-0 & 2.9 & LP & Center of Sparcap & Rosette \\
\hline SG18-2900-LP-SC-45 & 2.9 & LP & Center of Sparcap & Rosette \\
\hline SG19-2900-LP-SC-90 & 2.9 & LP & Center of Sparcap & Rosette \\
\hline SG20-2900-LP-FP-0 & 2.9 & LP & Mid Fore Panel & Rosette \\
\hline SG21-2900-LP-FP-45 & 2.9 & $\mathrm{LP}$ & Mid Fore Panel & Rosette \\
\hline SG22-2900-LP-FP-90 & 2.9 & $\mathrm{LP}$ & Mid Fore Panel & Rosette \\
\hline SG23-3250-HP-SC & 3.25 & $\mathrm{HP}$ & Center of Sparcap & Uni \\
\hline SG24-3250-LP-SC & 3.25 & LP & Center of Sparcap & Uni \\
\hline SG25-3250-LE & 3.25 & LP & LE & Uni \\
\hline SG26-3250-TE & 3.25 & LP & $\mathrm{TE}$ & Uni \\
\hline SG27-3250-LP-TE & 3.25 & LP & $\mathrm{TE}$ & Uni \\
\hline SG28-6300-LP-AP-0 & 6.3 & LP & Mid Aft Panel & Rosette \\
\hline SG29-6300-LP-AP-45 & 6.3 & LP & Mid Aft Panel & Rosette \\
\hline SG30-6300-LP-AP-90 & 6.3 & LP & Mid Aft Panel & Rosette \\
\hline SG31-6300-HP-LE-0 & 6.3 & $\mathrm{HP}$ & LE & Rosette \\
\hline SG32-6300-HP-LE-45 & 6.3 & $\mathrm{HP}$ & LE & Rosette \\
\hline SG33-6300-HP-LE-90 & 6.3 & HP & LE & Rosette \\
\hline SG34-6500-HP-SC & 6.5 & $\mathrm{HP}$ & Center of Sparcap & Uni \\
\hline SG35-6500-LP-SC & 6.5 & $\mathrm{LP}$ & Center of Sparcap & Uni \\
\hline SG36-6500-LE & 6.5 & LP & LE & Uni \\
\hline SG37-6500-TE & 6.5 & LP & $\mathrm{TE}$ & Uni \\
\hline SG38-9000-LP-AP-0 & 9 & LP & Mid Aft Panel & Rosette \\
\hline SG39-9000-LP-AP-45 & 9 & $\mathrm{LP}$ & Mid Aft Panel & Rosette \\
\hline SG40-9000-LP-AP-90 & 9 & LP & Mid Aft Panel & Rosette \\
\hline SG41-9750-HP-SC & 9.75 & $\mathrm{HP}$ & Center of Sparcap & Uni \\
\hline SG42-9750-LP-SC & 9.75 & LP & Center of Sparcap & Uni \\
\hline SG43-9750-LE & 9.75 & LP & LE & Uni \\
\hline
\end{tabular}




\begin{tabular}{|l|c|c|c|c|}
\hline \multicolumn{1}{|c|}{ Strain Gage Name } & Span & Surface & Chord Position & Type \\
\hline SG44-9750-TE & 9.75 & LP & TE & Uni \\
\hline SG45-3250-HP-TE & 3.25 & HP & TE & Uni \\
\hline
\end{tabular}

Table 8.6 provides specifications for the strain gages. For static testing, strain gage channels were zeroed before application of the first load step but after all hardware and rigging was installed on the blade (i.e. zeroed with tare weight). For fatigue testing, gages were periodically zeroed at mean load during calibration pulls (blade with load saddles and UREX installed).

Table 8.6. Strain Gage Specifications

\begin{tabular}{|c|c|c|}
\hline Type & Manufacturer & Model \\
\hline Single element Strain Gage & Vishay & WK-06-250BG-350 \\
\hline Rosette Strain Gage & Vishay & WK-06-250RA-350 \\
\hline
\end{tabular}

\section{4-Temperature and Humidity}

Ambient temperature and relative humidity were measured during the test. Measurements were taken near the blade root. Table 8.7 provides specifications for the temperature and relative humidity sensor.

\section{Table 8.7. Temperature and Humidity Sensor Specifications}

\begin{tabular}{|c|c|c|c|}
\hline Type & Manufacturer & Model & Serial \\
\hline $\begin{array}{c}\text { Temperature } \\
\text { Humidity }\end{array}$ & Omega & HX93BV2 & 1603050 \\
\hline
\end{tabular}

\section{5-Accelerometers}

Accelerometers were mounted to the blade during fatigue testing. Each accelerometer measured acceleration in both flap and edge (lead-lag) directions. Table 8.8 provides a list of the accelerometers locations used during fatigue testing. Accelerometers were mounted to the top surface of the blade.

Table 8.8. Accelerometer Specifications

\begin{tabular}{|l|l|l|l|l|}
\hline \multicolumn{1}{|c|}{ EDAS Channel Name } & \multicolumn{1}{|c|}{ Manufacturer } & \multicolumn{1}{c|}{ Model } & Serial & \multicolumn{1}{c|}{ Position } \\
\hline Accel1Flap & SDI & $2470-002$ & 3441 & Root HP \\
\hline Accel1LeadLag & SDI & $2470-002$ & 3441 & Root HP \\
\hline Accel2Flap & SDI & $2460-005$ & 1242 & $4.6 \mathrm{~m}$ UREX N \\
\hline Accel2LeadLag & SDI & $2460-005$ & 1242 & $4.6 \mathrm{~m}$ UREX N \\
\hline Accel3Flap & SDI & $2470-005$ & 3105 & $4.6 \mathrm{~m}$ UREX S \\
\hline Accel3LeadLag & SDI & $2470-005$ & 3105 & $4.6 \mathrm{~m}$ UREX S \\
\hline
\end{tabular}




\begin{tabular}{|l|l|l|l|l|}
\hline \multicolumn{1}{|c|}{ EDAS Channel Name } & \multicolumn{1}{|c|}{ Manufacturer } & \multicolumn{1}{c|}{ Model } & \multicolumn{1}{c|}{ Serial } & \multicolumn{1}{c|}{ Position } \\
\hline Accel4Flap & SDI & $2460-005$ & 1341 & $4.7 \mathrm{~m} \mathrm{TE}$ \\
\hline Accel4LeadLag & SDI & $2460-005$ & 1341 & $4.7 \mathrm{~m} \mathrm{TE}$ \\
\hline Accel5Flap & SDI & $2470-005$ & 3106 & $4.7 \mathrm{~m} \mathrm{LE}$ \\
\hline Accel5LeadLag & SDI & $2470-005$ & 3106 & $4.7 \mathrm{~m} \mathrm{LE}$ \\
\hline Accel6Flap & SDI & $2460-010$ & 1340 & $9.75 \mathrm{~m} \mathrm{TE}$ \\
\hline Accel6LeadLag & SDI & $2460-010$ & 1340 & $9.75 \mathrm{~m} \mathrm{TE}$ \\
\hline Accel7Flap & SDI & $2470-005$ & 2073 & $9.75 \mathrm{~m} \mathrm{LE}$ \\
\hline Accel7LeadLag & SDI & $2470-005$ & 2073 & $9.75 \mathrm{~m} \mathrm{LE}$ \\
\hline
\end{tabular}

\section{6 - Data Acquisition}

The Ethercat Data Acquisition System (EDAS) was used for static and fatigue testing. The EDAS is based on National Instruments (NI) Ethercat PXI technology combined with custom NREL developed LabVIEW coded software (software version 120120). All channels were scanned at $1000 \mathrm{~Hz}$ and recorded as time series data at $100 \mathrm{~Hz}$. For fatigue testing, data was also collected as peak/valley data pairs, recording the maximum and minimum values for each cycle of every channel.

\section{7-Property Testing Instrumentation}

A Chatillon crane scale was used to measure weight for the mass and CG balance. A 2-inch wide poly sling was used to lift the blade. A digital protractor was used to measure the inclination of the root face of the blade during the mass and CG balance. Table 8.9 provides specifications on the instruments used for weight and balance measurements.

Table 8.9. Property Testing Instrumentation Specifications

\begin{tabular}{|c|c|c|c|}
\hline Type & Manufacturer & Model & Serial \\
\hline Crane Scale & Chatillon & RDWT-2000 & 41998 \\
\hline Digital Protractor & Mitutoyo & PRO 3600 & $950-316$ \\
\hline
\end{tabular}

Instrumentation used for modal testing is provided in a separate report [2].

\section{9-APPLIED TEST LOADING}

\section{1 - Static Proof Load Cases}

Each proof load case was performed by applying the external loads of ballast weight and crane load. For each load case the loads were applied in three load ramps, at approximately $25 \%$, $50 \%$, and $100 \%$ of the target load. 


\section{2 - Fatigue Test Loading}

Fatigue test moments were applied by operating the UREX actuators at the system's natural frequency. The mean test moment was created by the static weight of the blade and saddles, including the weight of the UREX system. Moment amplitude was maintained by using dualmode feedback for UREX actuator amplitude control.

Periodically, a static load was applied to the blade at the $10.85 \mathrm{~m}$ saddle. Strain to moment sensitivities of select strain gages were then be used to calculate the applied bending moment under dynamic cycling through strain gage measurements.

\section{3 - Ultimate Static Load Case}

Loads were applied to the $10.85 \mathrm{~m}$ station saddle through a two-part rigging line connected to an electric winch. The initial ramp to $75 \%$ of anticipated failure moment was performed with the load cell beneath the load saddle. The load cell was moved to winch line during the load to failure.

\section{0-TESTING AND RESULTS}

\section{1-Property Testing}

Weight and CG measurements of the blade were performed with a single point lift prior to installing test instrumentation. A polyester lifting sling was choked around the blade at the center of gravity location. The lift was conducted with the blade positioned such that the trailing edge (TE) was up, towards the laboratory ceiling, and the leading edge (LE) was down, towards the laboratory floor. The sling position was adjusted along the span of the blade until the root face of the blade was vertical. The weight was measured with crane scale and the CG distance was measured with a tape measure from the root face of the blade to the center of the sling along the low-pressure (LP) surface. The results are presented in Table 10.1.

\section{Table 10.1. Weight and CG}

\begin{tabular}{|l|c|}
\hline \multicolumn{1}{|c|}{ Property } & Measured Values \\
\hline Weight $(\mathrm{kN})$ & 5.08 \\
\hline CG Location $(\mathrm{m})$ & 3.630 \\
\hline
\end{tabular}

Modal parameters were measured using free-decay and impact methods. The blade was cantilevered to the test stand in Building A-60 for modal characterization. Summary information of modal survey results is provided in Table 10.2. 
Table 10.2. Modal Survey Summary Results

\begin{tabular}{|l|r|r|}
\hline \multicolumn{1}{|c|}{ Mode Shape } & Frequency [Hz] & Damping [\% of Critical Damping] \\
\hline $1^{\text {st }}$ Flat & 2.19 & 0.11 \\
\hline $1^{\text {st }}$ Edge & 4.92 & 0.20 \\
\hline $2^{\text {nd }}$ Flat & 7.06 & 0.14 \\
\hline $3^{\text {rd }}$ Flat & 14.5 & 0.16 \\
\hline $2^{\text {nd }}$ Edge & 18.1 & 0.23 \\
\hline Flap / Torsion & 24.0 & 0.20 \\
\hline $1^{\text {st }}$ Torsion & 26.6 & 0.19 \\
\hline
\end{tabular}

\section{2-Static Proof Testing}

Blade static proof load testing followed the test plan. Table 10.3 provides the $100 \%$ applied test moments for each of the static proof load cases. Appendix A provides information on how the applied loads are calculated. Figure 10.1 provides the ratio between the applied test moment to the target test moment. The applied test moment exceeded the target test moment for ratios greater than 1.

Table 10.3. Applied Test Loads for Static Proof Load Cases

\begin{tabular}{|c|c|c|c|c|c|c|c|c|}
\hline & \multicolumn{2}{|c|}{ Maximum Flapwise } & \multicolumn{2}{c|}{ Minimum Flapwise } & \multicolumn{2}{c|}{ Maximum Edgewise } & \multicolumn{2}{c|}{ Minimum Edgewise } \\
\hline $\begin{array}{c}\text { Spanwise } \\
\text { Station [m] }\end{array}$ & $\begin{array}{c}\text { Target Test } \\
\text { Moment } \\
{[\mathrm{kN}-\mathrm{m}]}\end{array}$ & $\begin{array}{c}\text { Applied Test } \\
\text { Moment } \\
{[\mathrm{kN}-\mathrm{m}]}\end{array}$ & $\begin{array}{c}\text { Target Test } \\
\text { Moment } \\
{[\mathrm{kN}-\mathrm{m}]}\end{array}$ & $\begin{array}{c}\text { Applied Test } \\
\text { Moment } \\
{[\mathrm{kN}-\mathrm{m}]}\end{array}$ & $\begin{array}{c}\text { Target Test } \\
\text { Moment } \\
{[\mathrm{kN}-\mathrm{m}]}\end{array}$ & $\begin{array}{c}\text { Applied Test } \\
\text { Moment } \\
{[\mathrm{kN}-\mathrm{m}]}\end{array}$ & $\begin{array}{c}\text { Target Test } \\
\text { Moment } \\
{[\mathrm{kN}-\mathrm{m}]}\end{array}$ & $\begin{array}{c}\text { Applied Test } \\
\text { Moment } \\
{[\mathrm{kN}-\mathrm{m}]}\end{array}$ \\
\hline 0 & 224.90 & 222.51 & 195.80 & 192.28 & 166.80 & 169.64 & 159.40 & 163.19 \\
\hline 0.87 & 197.20 & 197.68 & 168.00 & 167.64 & 145.20 & 148.57 & 136.50 & 141.42 \\
\hline 1.82 & 171.70 & 171.24 & 139.30 & 141.39 & 124.20 & 126.22 & 112.60 & 118.32 \\
\hline 2.6 & 149.90 & 149.80 & 117.00 & 120.11 & 106.40 & 108.14 & 95.10 & 99.62 \\
\hline 3.48 & 126.50 & 125.96 & 93.90 & 96.46 & 87.50 & 88.10 & 77.20 & 78.88 \\
\hline 4.44 & 102.30 & 100.35 & 72.90 & 71.05 & 69.00 & 66.63 & 59.10 & 56.64 \\
\hline 5.46 & 77.90 & 79.02 & 53.10 & 53.74 & 52.10 & 51.58 & 43.30 & 42.71 \\
\hline 5.98 & 68.20 & 68.82 & 44.30 & 45.96 & 44.20 & 44.76 & 36.20 & 36.64 \\
\hline 7.02 & 48.60 & 48.63 & 30.20 & 30.60 & 30.80 & 31.34 & 24.70 & 24.73 \\
\hline 8.05 & 32.60 & 32.52 & 19.30 & 19.31 & 20.40 & 20.77 & 15.60 & 15.82 \\
\hline 9.05 & 21.00 & 20.80 & 11.40 & 12.31 & 12.60 & 13.25 & 9.10 & 10.07 \\
\hline 9.52 & 15.50 & 15.36 & 8.50 & 9.08 & 9.70 & 9.78 & 6.80 & 7.43 \\
\hline 10.4 & 8.70 & 5.28 & 4.50 & 3.16 & 5.00 & 3.40 & 3.70 & 2.60 \\
\hline 11.53 & 3.20 & 0.07 & 1.20 & 0.07 & 1.40 & 0.07 & 1.00 & 0.07 \\
\hline 12.37 & 0.30 & 0.01 & 0.20 & 0.01 & 0.20 & 0.01 & 0.10 & 0.01 \\
\hline 12.99 & 0.00 & 0.00 & 0.00 & 0.00 & 0.00 & 0.00 & 0.00 & 0.00 \\
\hline
\end{tabular}




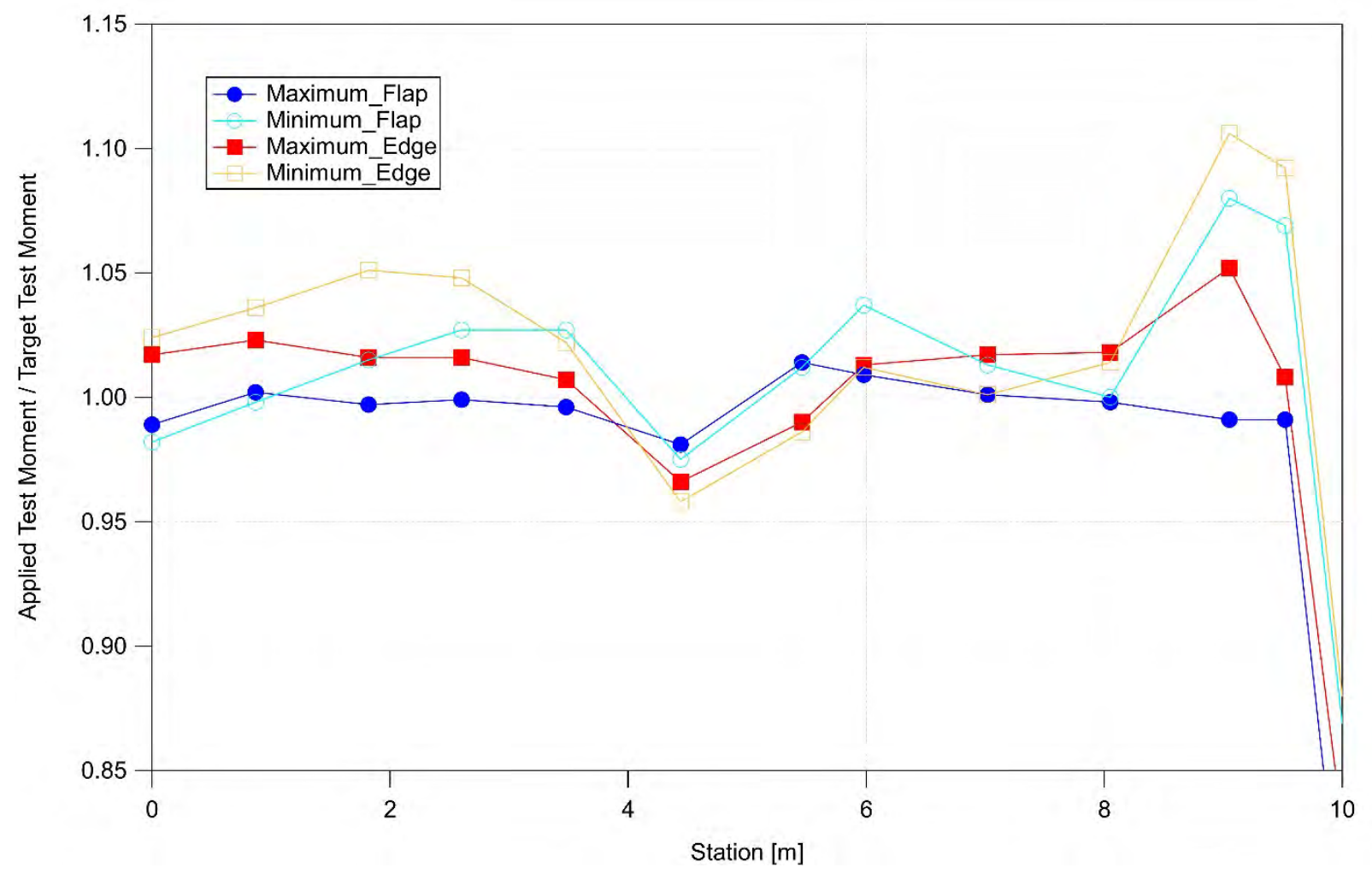

Figure 10.1. Static Proof Load Testing Applied to Target Load Ratio

Appendix B through Appendix E provide data charts for the $100 \%$ load ramps for each of the static proof load cases.

The blade sustained each of the proof load cases without evidence of damage or apparent changes in physical shape.

\section{3-Flapwise Fatigue Loading}

Testing was performed in attended operation, where staff was always present during loading. The test was stopped in the evening and restarted in the morning.

Table 10.4 provides the strain to moment sensitivities of gages located on the spar caps or root that were used to monitor applied moment. These sensitivities were calculated during calibration pulls performed periodically during testing. The sensitivity is the linear curve-fit slope of the strain versus applied moment curve. 
Table 10.4. Strain to Moment Sensitivities

\begin{tabular}{|c|c|r|r|r|r|r|}
\hline Strain Gage Information & \multicolumn{4}{|c|}{ Strain to Moment Sensitivity (kN m) } \\
\hline Strain Gage Name & $\begin{array}{c}\text { Strain Gage Span } \\
\text { Location [m] \Cal } \\
\text { Pull Date }\end{array}$ & $\mathbf{2 0 1 7 . 1 2 . 0 4}$ & $\mathbf{2 0 1 7 . 1 2 . 2 7}$ & $\mathbf{2 0 1 8 . 0 1 . 0 5}$ & $\mathbf{2 0 1 8 . 0 1 . 1 2}$ & $\mathbf{2 0 1 8 . 0 1 . 1 9}$ \\
\hline SG01-200-LP0 & 0.2 & 0.4667 & 0.4623 & 0.4584 & 0.4557 & 0.4569 \\
\hline SG05-200-HP180 & 0.2 & 0.4935 & 0.4718 & 0.4730 & 0.4732 & 0.4669 \\
\hline SG23-3250-HP-SC & 3.25 & 0.0444 & 0.0438 & 0.0440 & 0.0442 & 0.0439 \\
\hline SG24-3250-LP-SC & 3.25 & 0.0490 & 0.0477 & 0.0481 & 0.0483 & 0.0477 \\
\hline SG34-6500-HP-SC & 6.5 & 0.0229 & 0.0225 & 0.0226 & 0.0227 & 0.0225 \\
\hline SG35-6500-LP-SC & 6.5 & 0.0242 & 0.0236 & 0.0237 & 0.0239 & 0.0237 \\
\hline SG41-9750-HP-SC & 9.75 & 0.0076 & 0.0073 & 0.0073 & 0.0073 & 0.0073 \\
\hline SG42-9750-LP-SC & 9.75 & 0.0083 & 0.0078 & 0.0079 & 0.0079 & 0.0079 \\
\hline
\end{tabular}

Figure 10.2 compares the target 1 million cycle DEL with DEL's calculated from the applied fatigue test load. Appendix F provides the equations used to calculate the applied test DEL. An inverse slope parameter of 12 is used for this calculation. The low-pressure surface gages provided higher estimates of applied DEL, with an excepting being at the $0.2 \mathrm{~m}$ station. The DEL at the $0.2 \mathrm{~m}$ station is approximately $15 \%$ below the target DEL. Including moments in the lead-lag direction, the DEL at the $0.2 \mathrm{~m}$ station is approximately $8 \%$ below the target DEL. 


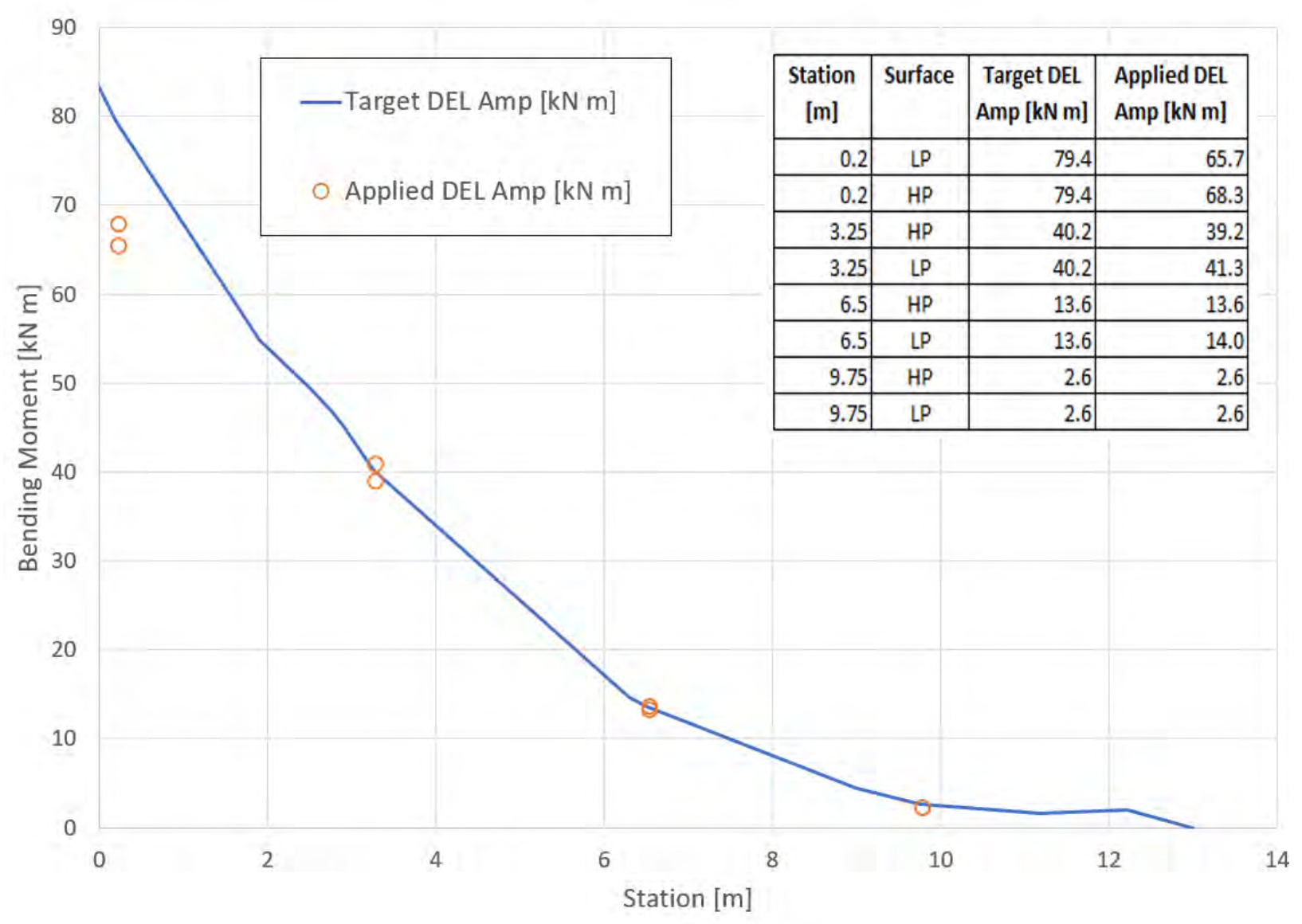

Figure 10.2. Target and Applied DEL's

Appendix $G$ provides data charts for the flapwise fatigue test. Data in these charts have been averaged in blocks of 50 cycles. Data collected during startup and shutdown (low amplitude response) have been filtered from charted data. Taking a snapshot of operating data, Table 10.5 provides data ranges (peak-to-peak) at a cycle count of 1 million cycles.

Table 10.5. Data ranges at the 1-million cycle mark

\begin{tabular}{|l|r|l|l|r|l|}
\hline \multicolumn{1}{|c|}{ Channel Name } & $\begin{array}{c}\text { Range @ } \\
\text { 1e6 Cycles }\end{array}$ & Units & \multicolumn{1}{|c|}{ Channel Name } & $\begin{array}{c}\text { Range @ } \\
\text { 1e6 Cycles }\end{array}$ & Units \\
\hline LVDT-S & 83.4 & $\mathrm{~mm}$ & SG14-2500-HP-AP-90 & 459 & ue \\
\hline Temperature (Average Value) & 20.5 & $\mathrm{C}$ & SG15-2750-HP-TE & 609 & ue \\
\hline Humidity (Average Value) & 11.0 & $\%$ RH & SG16-2750-TE & 551 & ue \\
\hline LDT & 1.86 & $\mathrm{~mm}$ & SG17-2900-LP-SC-0 & 2057 & ue \\
\hline A-Tip-Flap & 8.111 & $\mathrm{~g}$ & SG18-2900-LP-SC-45 & 654 & ue \\
\hline A-Tip-LeadLag & 1.892 & $\mathrm{~g}$ & SG19-2900-LP-SC-90 & 511 & ue \\
\hline A-4700TE-Flap & 0.804 & $\mathrm{~g}$ & SG20-2900-LP-FP-0 & 1308 & ue \\
\hline
\end{tabular}




\begin{tabular}{|c|c|c|c|c|c|}
\hline Channel Name & $\begin{array}{c}\text { Range @ } \\
\text { 1e6 Cycles }\end{array}$ & Units & Channel Name & $\begin{array}{c}\text { Range @ } \\
\text { 1e6 Cycles }\end{array}$ & Units \\
\hline A-4700TE-LeadLag & 0.260 & $\mathrm{~g}$ & SG21-2900-LP-FP-45 & 616 & ue \\
\hline A-9750TE-Flap & 4.357 & $\mathrm{~g}$ & SG22-2900-LP-FP-90 & 608 & ue \\
\hline A-9750TE-LeadLag & 1.315 & $\mathrm{~g}$ & SG23-3250-HP-SC & 1801 & ue \\
\hline A-9750LE-Flap & 4.333 & $\mathrm{~g}$ & SG24-3250-LP-SC & 1741 & ue \\
\hline A-9750LE-LeadLag & 1.248 & $\mathrm{~g}$ & SG25-3250-LE & 212 & ue \\
\hline A-4600UREXSouth-Flap & 1.498 & $\mathrm{~g}$ & SG26-3250-TE & 615 & ue \\
\hline A-4600UREXSouth-LeadLag & 1.014 & $\mathrm{~g}$ & SG27-3250-LP-TE & 546 & ue \\
\hline A-4700LE-Flap & 0.842 & $\mathrm{~g}$ & SG28-6300-LP-AP-0 & 645 & ue \\
\hline A-4700LE-LeadLag & 0.246 & $\mathrm{~g}$ & SG29-6300-LP-AP-45 & 302 & ue \\
\hline A-4600UREXNorth-Flap & 0.853 & $\mathrm{~g}$ & SG30-6300-LP-AP-90 & 376 & ue \\
\hline A-4600UREXNorth-LeadLag & 0.278 & $\mathrm{~g}$ & SG31-6300-HP-LE-0 & 129 & ue \\
\hline A-Root-Flap & 0.002 & $\mathrm{~g}$ & SG32-6300-HP-LE-45 & 57 & ue \\
\hline A-Root-LeadLag & 0.004 & $\mathrm{~g}$ & SG33-6300-HP-LE-90 & 133 & ue \\
\hline SG01-200-LP0 & 290 & ue & SG34-6500-HP-SC & 1221 & ue \\
\hline SG02-200-LP45 & 247 & ue & SG35-6500-LP-SC & 1197 & ue \\
\hline SG03-200-LP90 & 52 & ue & SG36-6500-LE & 108 & ue \\
\hline SG04-200-LP135 & 157 & ue & SG37-6500-TE & 534 & ue \\
\hline SG05-200-HP180 & 295 & ue & SG38-9000-LP-AP-0 & 345 & ue \\
\hline SG06-200-HP225 & 270 & ue & SG39-9000-LP-AP-45 & 193 & ue \\
\hline SG07-200-HP270 & 57 & ue & SG40-9000-LP-AP-90 & 175 & ue \\
\hline SG08-200-HP315 & 151 & ue & SG41-9750-HP-SC & 716 & ue \\
\hline SG09-1900-HP-AP-0 & 279 & ue & SG42-9750-LP-SC & 673 & ue \\
\hline SG10-1900-HP-AP-45 & 106 & ue & SG43-9750-LE & 124 & ue \\
\hline SG11-1900-HP-AP-90 & 230 & ue & SG44-9750-TE & 247 & ue \\
\hline SG12-2500-HP-AP-0 & 618 & ue & SG45-3250-HP-TE & 669 & ue \\
\hline SG13-2500-HP-AP-45 & 93 & ue & SG46-2750-LP-TE & 487 & ue \\
\hline
\end{tabular}

A 'Clicking' noise was noted around the $2.9 \mathrm{~m}$ station early in testing but diminished as the test progressed. Beyond the initial strain drift at the $2.9 \mathrm{~m}$ station (SG 17, SG18, and SG19) no abnormal behavior was observed in strain or acceleration data.

\section{4-Ultimate Positive Flapwise Static Load}

The $75 \%$ (of maximum flap proof) and load to failure were the final structural loads applied to the blade. During the ramp to failure the load cell was between the winch and turning blocks. The turning blocks add friction that reduces the applied load reading. From this, strain to moment sensitivities were used to estimate the applied test load at the time of failure. The blade failed near the $2.9 \mathrm{~m}$ station. Reviewing video, the skin and shear web on the low- 
pressure surface was observed to buckle prior to failure. The applied test bending moment at the $2.9 \mathrm{~m}$ station when the blade failed catastrophically was $228.7 \mathrm{kN} \mathrm{m}$. Table 10.5 provides the strain to load sensitivities used to calculate the applied test bending moment at the time of failure. Figure 10.3 provides the applied test bending moment at failure, as calculated using strain to load sensitivities.

Table 10.5. Strain to Moment Sensitivities for Ultimate Static Flapwise Moment Calculation

\begin{tabular}{|l|l|l|l|l|l|}
\hline Strain Gage & $\begin{array}{l}\text { Station } \\
{[\mathrm{m}]}\end{array}$ & $\begin{array}{l}\text { Strain to Load } \\
\text { sensitivity [kN / ue] }\end{array}$ & $\begin{array}{l}\text { Strain } \\
\text { Offset [ue] }\end{array}$ & $\begin{array}{l}\text { Strain at } \\
\text { Failure [ue] }\end{array}$ & $\begin{array}{l}\text { Moment at Failure } \\
{[\mathrm{kN} \mathrm{m}]}\end{array}$ \\
\hline SG23-3250-HP-SC & 3.25 & 0.003457 & 1566 & 4970 & 214.4 \\
\hline SG24-3250-LP-SC & 3.25 & -0.00318 & -1437 & -4342 & 214.4 \\
\hline SG34-6500-HP-SC & 6.5 & 0.003826 & 690 & 4361 & 100.2 \\
\hline SG35-6500-LP-SC & 6.5 & -0.00373 & -668 & -4214 & 100.2 \\
\hline
\end{tabular}

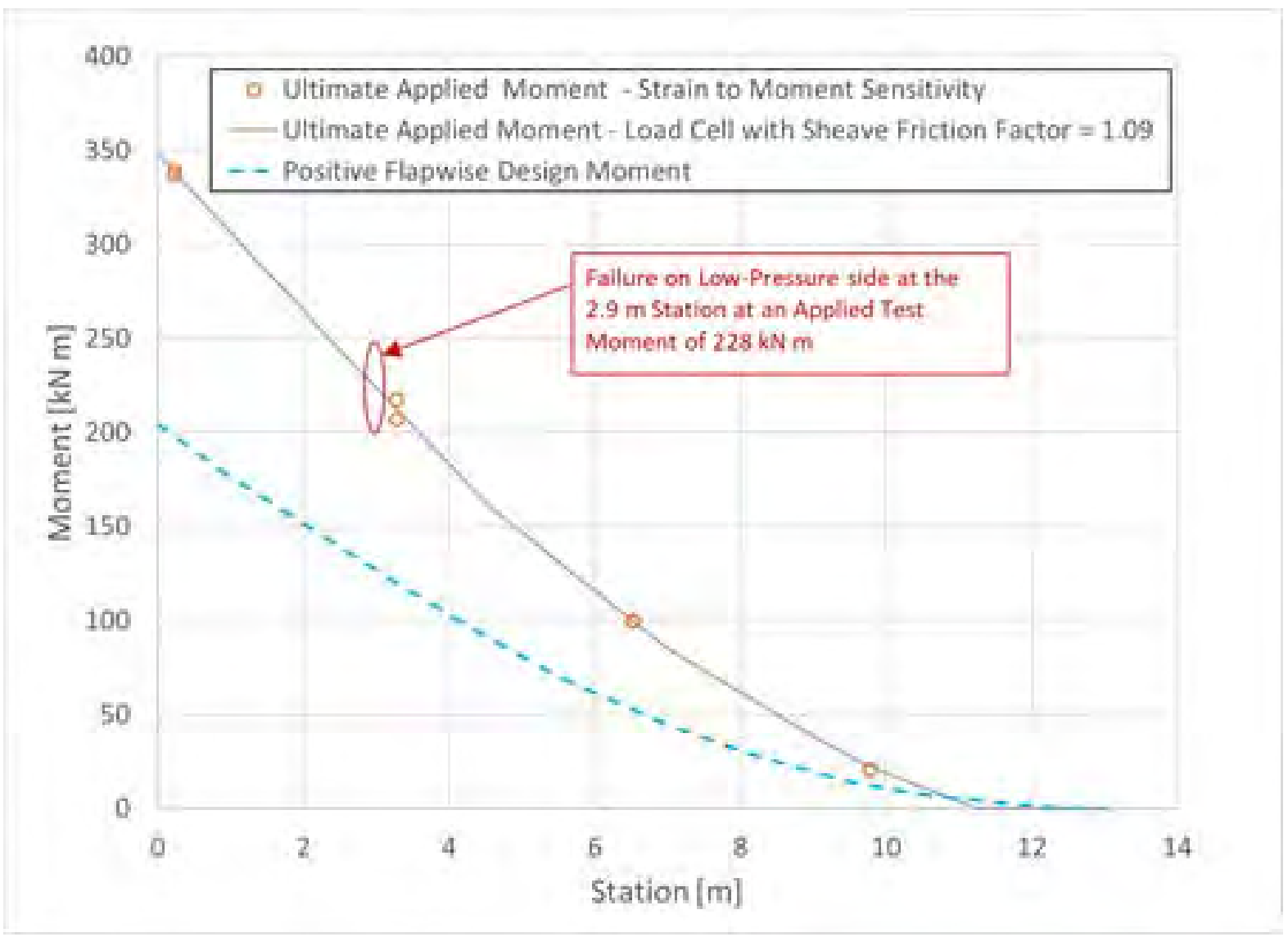

Figure 10.3. Applied Flapwise Static Moment at Failure 
Figure 10.4 shows the low-pressure surface of the blade just before and after failure. The lightcolored area in the photo on the left is centered near the $2.9 \mathrm{~m}$ station. Video will more clearly show this area was bulging out prior to failure
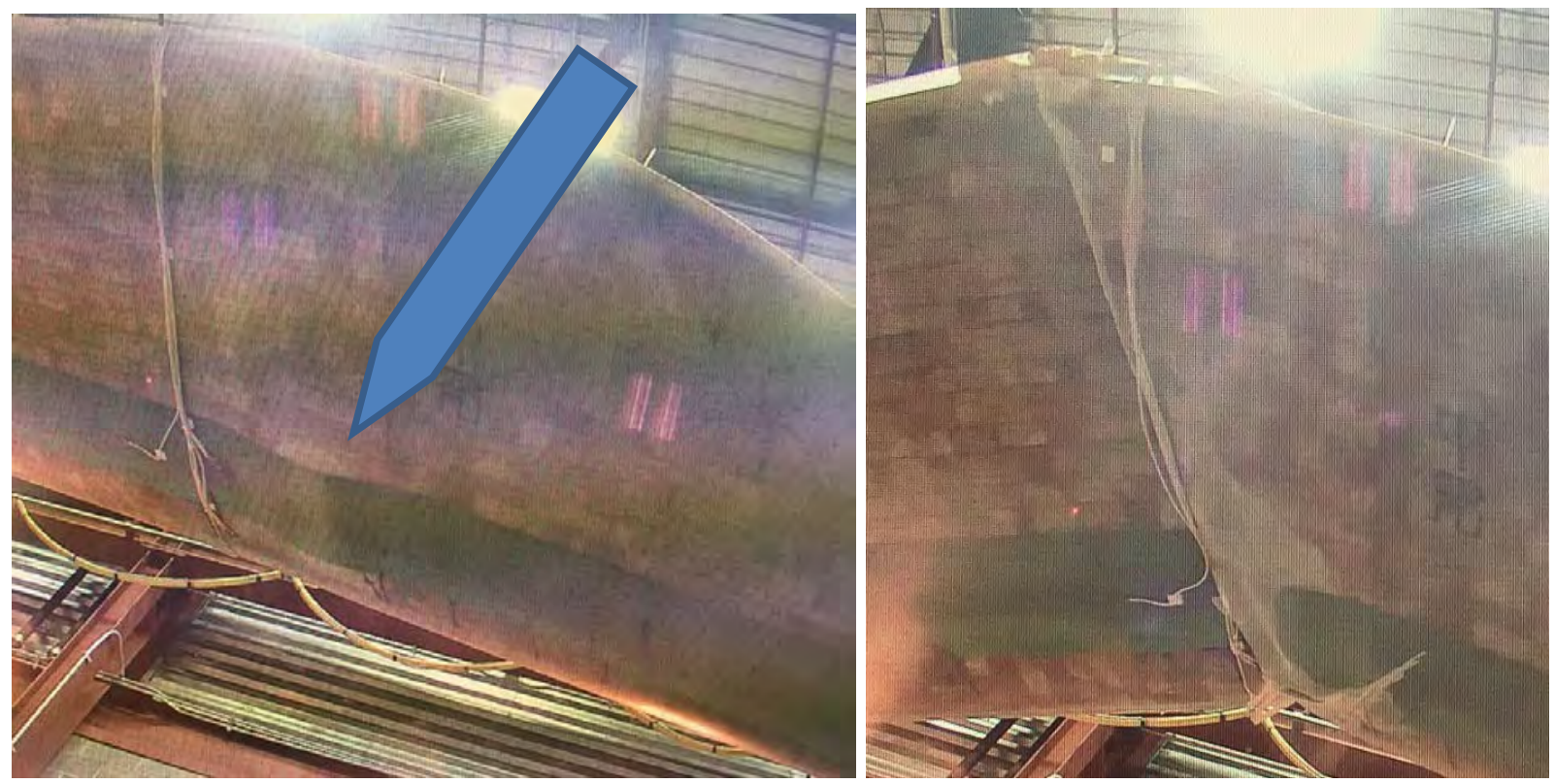

Figure 10.4. Low-pressure Blade Surface Before and After Failure

Appendix $\mathrm{H}$ provides data charts for the ultimate positive flapwise static test.

\section{1-SECTION WEIGHT BALANCE}

Following the completion of structural testing and the failure of the blade during the ultimate static load case the blade was sectioned into 13 sections along the length of the blade, each section was approximately 1 meter in length. The CG of each section was determined by balancing the section on a length of angle iron. The weight of the sections was measured by placing the sections on a platform scale. Table 9.1 provides data collected during blade sectioning. At several locations noted in Table 11.1, the aluminum bar of the Lightning Protection System (LPS) was observed to be broken. 
Table 11.1. Blade Section Weight Balance Summary

\begin{tabular}{|c|c|c|c|c|c|c|c|c|}
\hline $\begin{array}{l}\text { Section } \\
\quad \#\end{array}$ & $\begin{array}{l}\text { Nominal } \\
\text { Section } \\
\text { Start } \\
{[\mathrm{mm}]}\end{array}$ & $\begin{array}{l}\text { Nominal } \\
\text { Section } \\
\text { End } \\
\text { [mm] }\end{array}$ & $\begin{array}{l}\text { Section } \\
\text { Length } \\
\text { at LE } \\
{[\mathrm{mm}]}\end{array}$ & $\begin{array}{l}\text { Section } \\
\text { Length } \\
\text { at TE } \\
{[\mathrm{mm}]}\end{array}$ & $\begin{array}{l}\text { Chord } \\
\text { Length at } \\
\text { root side } \\
\text { [mm] }\end{array}$ & $\begin{array}{c}\text { Section CG } \\
\text { from root } \\
\text { end along } \\
\text { spar cap } \\
\text { [mm] }\end{array}$ & $\begin{array}{c}\text { Mass } \\
{[\mathrm{kg}]}\end{array}$ & Notes \\
\hline 1 & 0 & 1000 & 994 & 1014 & 584 & 323 & 138.2 & \\
\hline 2 & 1000 & 2000 & 992 & 1107 & 812 & 518 & 55.4 & $\begin{array}{l}\text { center cracked / } \\
\text { delamination on LP side }\end{array}$ \\
\hline 3 & 2000 & 3000 & 996 & 996 & 1361 & 486 & 50.8 & LE/center splintered \\
\hline 4 & 3000 & 4000 & 897 & 890 & 1465 & 427 & 41 & $\begin{array}{l}\text { trailing edge split, center } \\
\text { broken, detached }\end{array}$ \\
\hline 5 & 4000 & 5000 & 1093 & 1100 & 1382 & 536 & 46.5 & $\begin{array}{l}\text { trailing edge split, } \\
\text { Aluminum (LPS) broken }\end{array}$ \\
\hline 6 & 5000 & 6000 & 1002 & 997 & 1244 & 496 & 37.5 & \\
\hline 7 & 6000 & 7000 & 999 & 1005 & 1106 & 489 & 32.9 & $\begin{array}{l}\text { Lightning Protection } \\
\text { System (LPS) Aluminum } \\
\text { bar broken at mid span }\end{array}$ \\
\hline 8 & 7000 & 8000 & 996 & 1000 & 980 & 484 & 29.5 & \\
\hline 9 & 8000 & 9000 & 996 & 994 & 879 & 497 & 25.9 & \\
\hline 10 & 9000 & 10000 & 999 & 1014 & 790 & 487 & 22 & \\
\hline 11 & 10000 & 11000 & 994 & 988 & 702 & 483 & 18 & \\
\hline 12 & 11000 & 12000 & 997 & 1002 & 619 & 478 & 13.7 & $\begin{array}{l}\text { Added expanding foam } \\
\text { to secure LPS. Great Stuff } \\
\text { foam weight of } 16 \mathrm{oz} \\
{[0.45 \mathrm{~kg}]}\end{array}$ \\
\hline 13 & 12000 & 13000 & 1018 & & 483 & 441 & 8.7 & $\begin{array}{l}\text { Length measured along } \\
\text { center of spar cap. A } \\
\text { small amount of added } \\
\text { foam in this section }\end{array}$ \\
\hline
\end{tabular}




\section{2-MEASUREMENT UNCERTAINTITY}

Table 12.1 provides uncertainty estimates for the recorded measurements with a $95 \%$ level of confidence (coverage factor $\mathrm{k}=2$ ).

Table 12.1. Uncertainty Budget

\begin{tabular}{|l|l|l|l|l|l|}
\hline Instrument & Manufacturer & Model No. & $\begin{array}{l}\text { Estimate of } \\
\text { the } \\
\text { Measurand }\end{array}$ & $\begin{array}{l}\text { Expanded } \\
\text { Uncertainty }\end{array}$ & $\begin{array}{l}\text { Effective } \\
\text { degrees of } \\
\text { freedom } \\
\left(V_{\text {eff }}\right)\end{array}$ \\
\hline Temperature & Omega & HX93* & $20{ }^{\circ} \mathrm{C}$ & $1.0{ }^{\circ} \mathrm{C}$ & $>1 \mathrm{E}+03$ \\
\hline Humidity & Omega & HX93* & $50 \% \mathrm{RH}$ & $8.0 \% \mathrm{RH}$ & 57 \\
\hline Load Cell & MTS & $661.20 \mathrm{E}-02$ & -- & $0.2 \% \mathrm{RD}$ & $>1 \mathrm{E}+03$ \\
\hline String Pot & Unimeasure & HX-PA- ${ }^{*}$ & -- & $0.5 \% \mathrm{RD}$ & $>1 \mathrm{E}+03$ \\
\hline $\begin{array}{l}\text { Strain Gage } \\
\text { Element }\end{array}$ & Vishay & $\begin{array}{l}\text { WK-06-250BG-350 } \\
\text { WK-06-250RA-350 }\end{array}$ & 1000 ue & $3.0 \% \mathrm{RD}$ & $>1 \mathrm{E}+03$ \\
\hline Torque wrench & ${ }^{*}$ & ${ }^{*}$ & -- & $10 \% \mathrm{RD}$ & $>1 \mathrm{E}+03$ \\
\hline Crane Scale & Chatillon & ${ }^{*}$ & -- & $0.5 \% \mathrm{RD}$ & $>1 \mathrm{E}+03$ \\
\hline Tape measure & ${ }^{*}$ & ${ }^{*}$ & -- & $0.3 \% \mathrm{RD}$ & $>1 \mathrm{E}+03$ \\
\hline
\end{tabular}

* $=$ various manufacturers/models

$\% \mathrm{RD}=$ percent reading

$\% \mathrm{RH}=$ percent relative humidity

\section{3-EXCEPTIONS FROM STANDARD PRACTICE}

\section{1-Deviations from the Test Plans}

1. Modified weight of the UREX saddle and the number of UREX's employed for fatigue testing.

2. LVDT initially recording in inches

\section{2-Deviations from the IEC 61400-23 Standard}

1. The inside of the blade was not inspected between static and fatigue test programs 


\section{3-Deviations from the NREL Quality Assurance Program}

1. The lifting strap used to hoist the blade was used in a choked configuration during weight balancing, the internal procedure calls for the lifting strap to be used in a basket configuration.

\section{4-REFERENCES}

1. Airfoil profile data. MS Excel file 'NRT Airfoil Points (180222).xlsx', and 'all sections and spar cap Combined tabdelim (180222).txt'. Sent on 22 February 2018 to Josh Paquette from Scott Hughes.

2. NREL Test Report. Sandia NRT Blade-0 Laboratory Modal Survey. May 1, 2018

3. NREL Report. Blade Sectioning and Weight Balancing of the SNL NRT Blade 0 Sections.

4. Interagency Agreement. SNL Standard Purchase Order 1793182.

5. IEC, Wind turbines-Part23:: Full-scale structural testing of rotor blades, IEC, 2014.

6. http://www.a2la.org/scopepdf/1239-01.pdf

7. Safe Operating Procedures, No. 515009412, Conducting Structural Tests at the NWTC.

8. NREL Static Test Plan. Laboratory Maximum Flapwise Static Testing of the Sandia National Rotor Testbed 13-meter Wind Turbine Blade. 30 June 2017.

9. NREL Static Test Plan. Laboratory Minimum Flapwise, and Maximum and Minimum Edgewise, Static Testing of the Sandia National Rotor Testbed 13-meter Wind Turbine Blade. 7 August 2017.

10. NREL Fatigue Test Plan. Laboratory Flapwise Fatigue Testing of the Sandia National Rotor Testbed 13-meter Wind Turbine Blade. 5 December 2017.

11. NREL Static Test Plan. Laboratory Ultimate Flapwise Static Testing of the Sandia National Rotor Testbed 13-meter Wind Turbine Blade. 29 January 2018.

\section{5-LIST OF APPENDICIES}

Appendix A - Applied Test Moment Calculation

Appendix B - Data Charts for Maximum Flapwise Proof Loading

Appendix C - Data Charts for Minimum Flapwise Proof Loading

Appendix D - Data Charts for Maximum Edge Proof Loading

Appendix E - Data Charts for Minimum Edge Proof Loading

Appendix F - Fatigue Damage Equivalent Load Calculation

Appendix G - Data Charts for Flapwise Fatigue Loading

Appendix H - Data Charts for Ultimate Positive Flapwise Loading

Appendix I - Test Photographs 


\section{APPENDIX A- Applied Test Moment Calculation for Static Proof Load Cases}

This appendix provides parameters and equations used to calculate the Applied Test Moment (ATM). The ATM includes tare loads and external loads. For all static test load cases, the applied test loads were acting with gravity, being applied downward toward the laboratory floor. Tare load at each load station includes all weight suspended by the blade from load saddle to load cell. This includes saddles, rigging hardware like chains, shackles, spreader bar, and the weight of the load cell. In addition to the tare loads from rigging equipment and the external loads, the self-weight of the blade creates an additional bending moment. External loads were applied by hanging ballast weights or applying loads with the overhead crane. External loads were measured by the inboard and outboard load cells. The ATM is calculated by summing the contributions from rigging tare, blade self-weight tare, and the external load. Figure A-1 provides a schematic of the dimension used to calculate the ATM.

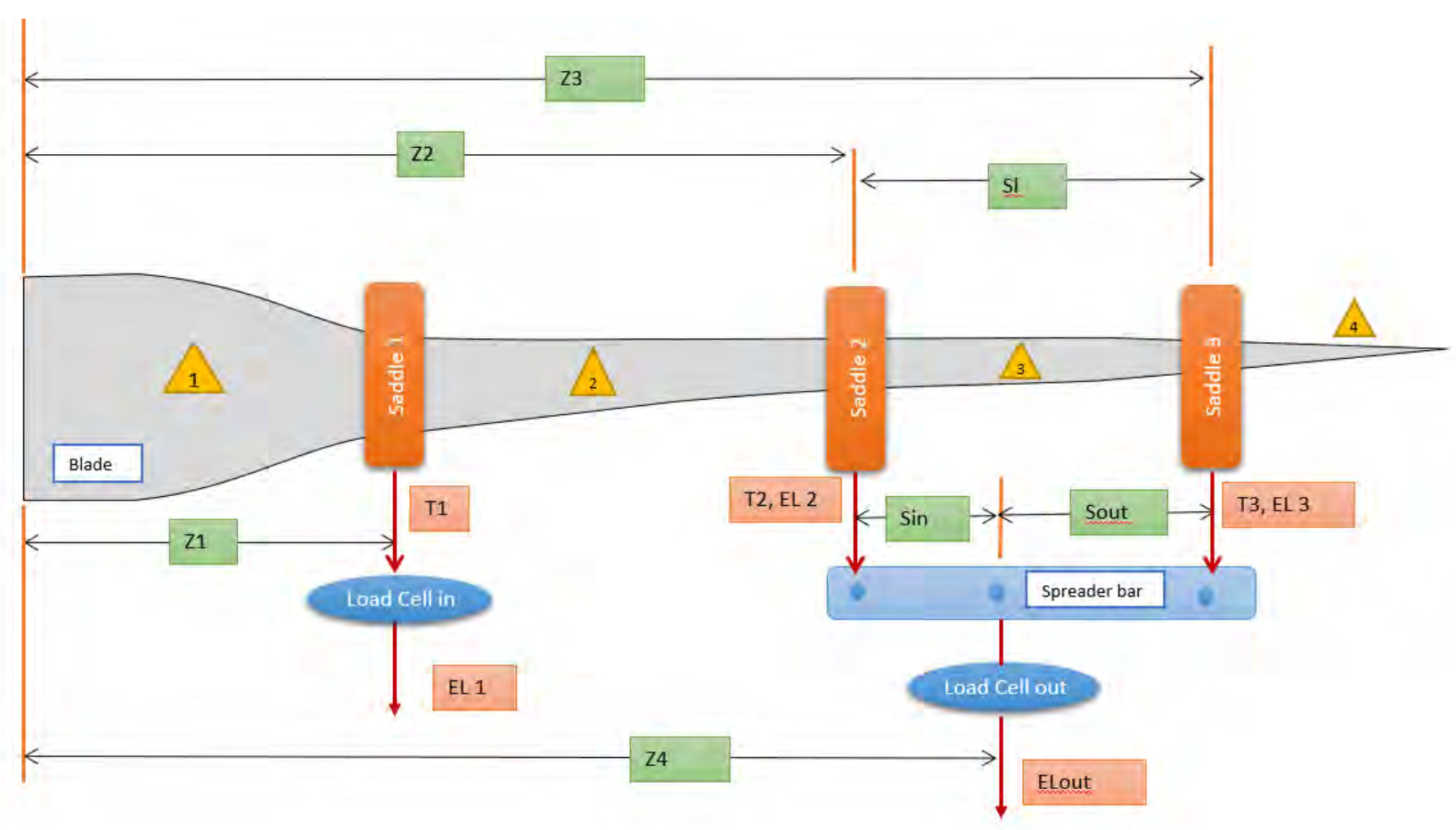

Figure A-1 - Dimensions used for calculating the Applied Test Moment

In addition to the load saddles, a spreader bar was used to apply loads at the $7.55 \mathrm{~m}$ and 10.85 $\mathrm{m}$ stations by dividing the outboard external load of the overhead crane (reacted through turning blocks to pull down towards the laboratory floor). The tare weight of the spreader bar was taken to be evenly distributed between the $7.55 \mathrm{~m}$ and $10.85 \mathrm{~m}$ stations. The center of gravity of the spreader bar is offset from the center of the beam as the reaction point hardware connecting to the external winch line was not always positioned at the center of the beam. This difference in the center of gravity of the spreader bar is considered negligible. The weight of instrumentation and cables placed on the blade for strain gages and accelerometers was not included in tare weight values. Table A-1 provides dimensions and rigging tare weights. 
Table A-1 - Test setup geometry and rigging tare weights

\begin{tabular}{|c|c|c|c|c|c|c|c|c|c|c|c|c|}
\hline Load Case & $\mathrm{Z1}[\mathrm{m}]$ & $\mathrm{Z} 2[\mathrm{~m}]$ & Z3 [m] & $\mathrm{Z} 4[\mathrm{~m}]$ & $\mathrm{T} 1[\mathrm{~N}]$ & $\mathrm{T} 2[\mathrm{~N}]$ & $\mathrm{T} 3[\mathrm{~N}]$ & $\mathrm{SI}[\mathrm{m}]$ & $\operatorname{Sin}[\mathrm{m}]$ & Sout [m] & $\begin{array}{c}E L 2 \\
\text { [fraction } \\
\text { of } E L \text { out] }\end{array}$ & $\begin{array}{c}\text { EL } 3 \\
\text { [Fraction } \\
\text { of EL out] }\end{array}$ \\
\hline Maximum Flap & \multirow{4}{*}{4.6} & \multirow{4}{*}{7.55} & \multirow{4}{*}{10.85} & 9.679 & 1923.9 & 1896.1 & 1555.8 & \multirow{4}{*}{3.299} & 2.129 & 1.170 & 0.355 & 0.645 \\
\hline Minimum Flap & & & & 9.120 & 1923.9 & 1896.1 & 1555.8 & & 1.570 & 1.729 & 0.524 & 0.476 \\
\hline Maximum Edge & & & & 9.679 & 2012.8 & 1896.1 & 1555.8 & & 2.129 & 1.170 & 0.355 & 0.645 \\
\hline Minimum Edge & & & & 9.279 & 1923.9 & 1896.1 & 1555.8 & & 1.729 & 1.570 & 0.476 & 0.524 \\
\hline
\end{tabular}

\begin{tabular}{|l|l|}
\hline \multicolumn{2}{|l|}{ Viariable Description } \\
\hline Z1 & Distance from root to Saddle 1 \\
\hline Z2 & Distance from root to Saddle 2 \\
\hline Z3 & Distance from root to Saddle 3 \\
\hline Z4 & Distance from root to effective outboard load station \\
\hline T1 & Tare load at Saddle 1 \\
\hline T2 & Tare load at Saddle 2 \\
\hline T3 & Tare load at Saddle 3 \\
\hline SI & Spreader length \\
\hline Sin & Distance between Saddle 2 and external outboard load station \\
\hline Sout & Distance between external outboard load station and Saddle 3 \\
\hline EL 2 & Fraction of external outboard load applied at Saddle 2 \\
\hline EL 3 & Fraction of external outboard load applied at Saddle 3 \\
\hline
\end{tabular}

The tare moment created by the self-weight of the blade was estimated based on mass per unit length data provided in the design document and then scaled by the root bending moment calculated by laboratory mass balance measurements performed prior to structural testing. To calculate self-weight bending moment, the blade was discretized into sections between the stations given in the design information document. The CG of each of these sections was calculated as the center of a trapezoid with lengths equal to the design mass per unit at the section end points. For most sections, the sectional CG calculated as a trapezoid is very close to taking the section $\mathrm{CG}$ as the midpoint of the section. As the design mass per unit length did not include the weight of the steel root inserts, a mass of $22 \mathrm{~kg}$ was added at the $\mathrm{z}=0.1 \mathrm{~m}$ station, where $(z)$ is the distance from the root face of the blade. For a measured blade weight of $5.08 \mathrm{kN}$ and CG $3.63 \mathrm{~m}$ from root, the calculated root bending moment due to blade selfweight is $18.44 \mathrm{kN}$. This result is more conservative relative to the weight and CG measured during the post mortem as less self-weight moment is included in the applied test load. Table A2 provides the bending moment from blade self-weight based on design information and the estimated bending moment based from blade self-weight scaled to the as-measured CG and mass of the blade. Values for estimated self-weight bending moment $\left(M_{Z}^{S W}\right)$ are used for reporting. 
Table A-2 - Design and estimated as-built blade self-weight bending moment.

\begin{tabular}{|c|c|c|}
\hline $\begin{array}{l}\text { Spanwise Station } \\
{[\mathrm{m}]}\end{array}$ & $\begin{array}{l}\text { Self-weight Bending Moment from } \\
\text { Design Information [ } \mathrm{N} \mathrm{m}]\end{array}$ & $\begin{array}{c}\text { Estimated Self Weight Bending } \\
\text { Moment based on measured } \\
\text { Weight and CG [ } \mathrm{N} \mathrm{m}]\end{array}$ \\
\hline 0.000 & 20657.901 & 18440.000 \\
\hline 0.125 & 20000.801 & 17853.449 \\
\hline 0.250 & 19406.843 & 17323.260 \\
\hline 0.670 & 17654.259 & 15758.839 \\
\hline 0.850 & 16958.791 & 15138.039 \\
\hline 1.525 & 14492.652 & 12936.673 \\
\hline 2.200 & 12254.007 & 10938.376 \\
\hline 2.605 & 11023.899 & 9840.337 \\
\hline 3.482 & 8647.698 & 7719.252 \\
\hline 4.443 & 6472.733 & 5777.799 \\
\hline 5.458 & 4615.954 & 4120.370 \\
\hline 6.115 & 3627.839 & 3238.342 \\
\hline 7.023 & 2507.295 & 2238.103 \\
\hline 7.542 & 1982.957 & 1770.060 \\
\hline 8.054 & 1540.916 & 1375.478 \\
\hline 8.950 & 929.844 & 830.013 \\
\hline 9.518 & 638.136 & 569.623 \\
\hline 10.402 & 311.556 & 278.106 \\
\hline 11.184 & 132.383 & 118.170 \\
\hline 11.650 & 65.832 & 58.764 \\
\hline 12.125 & 23.767 & 21.215 \\
\hline 12.460 & 7.548 & 6.738 \\
\hline 12.738 & 1.247 & 1.113 \\
\hline 12.865 & 0.202 & 0.180 \\
\hline 12.947 & 0.018 & 0.016 \\
\hline 13.000 & 0.000 & 0.000 \\
\hline
\end{tabular}

Creating a spline fit of the information in Table A-2, Table A-3 provides the estimated blade selfweight bending moment at saddle and strain gage locations. These values are used for reporting moment versus strain. 
Table A-3 - Design and estimated as-built blade self-weight bending moment at select blade stations.

\begin{tabular}{|c|c|}
\hline Station [m] & $\begin{array}{c}\text { Estimated Self-Weight } \\
\text { Bending Moment based } \\
\text { on Measured Weight and } \\
\text { CG [N m] }\end{array}$ \\
\hline 0.000 & 18440 \\
\hline 0.200 & 17529 \\
\hline 1.900 & 11801 \\
\hline 2.500 & 10118 \\
\hline 2.750 & 9466 \\
\hline 2.900 & 9088 \\
\hline 3.250 & 8247 \\
\hline 4.000 & 6625 \\
\hline 4.600 & 5496 \\
\hline 6.300 & 3015 \\
\hline 6.500 & 2785 \\
\hline 7.000 & 2261 \\
\hline 9.000 & 805 \\
\hline 9.700 & 499 \\
\hline 9.750 & 480 \\
\hline 11.250 & 108 \\
\hline
\end{tabular}

Given the geometry and values of rigging tare and blade self-weight moments provided above, the ATM can be calculated by including the external loads measured during testing. The external loads applied to Saddle 2 and Saddle 3 by the outboard external load is calculated with the following equations.

$$
\begin{gathered}
E L_{2}=E L_{\text {out }}\left(\frac{S_{L}-S_{\text {in }}}{S_{L}}\right) \\
E L_{3}=E L_{\text {out }}\left(\frac{S_{\text {in }}}{S_{L}}\right)
\end{gathered}
$$

Between the root of the blade and Saddle 1 (Section 1) the Applied Test Moment is then calculated as:

$$
A T M_{\text {Section } 1}=M_{z}^{S W}+\left\{\left(T_{1}+E L_{1}\right) *\left(Z_{1}-z\right)\right\}+\left\{\left(T_{2}+E L_{2}\right) *\left(Z_{2}-z\right)\right\}+\left\{\left(T_{3}+E L_{3}\right) *\left(Z_{3}-z\right)\right\}
$$

Again, $(z)$ is the distance from the root of the blade where the ATM is calculated. Between Saddle 1 and Saddle 2 (Section 2) the Applied Test Moment is calculated as:

$$
A T M_{\text {Section } 2}=M_{z}^{S W}+\left\{\left(T_{2}+E L_{2}\right) *\left(Z_{2}-z\right)\right\}+\left\{\left(T_{3}+E L_{3}\right) *\left(Z_{3}-z\right)\right\}
$$

Between Saddle 2 and Saddle 3 (Section 3) the Applied Test Moment is calculated as:

$$
A T M_{\text {Section } 3}=M_{Z}^{S W}+\left\{\left(T_{3}+E L_{3}\right) *\left(Z_{3}-z\right)\right\}
$$


Outboard of Saddle 3 (Section 4) the Applied Test Moment is simply the moment due to blade self-weight, given as:

$$
A T M_{\text {Section } 4}=M_{Z}^{S W}
$$



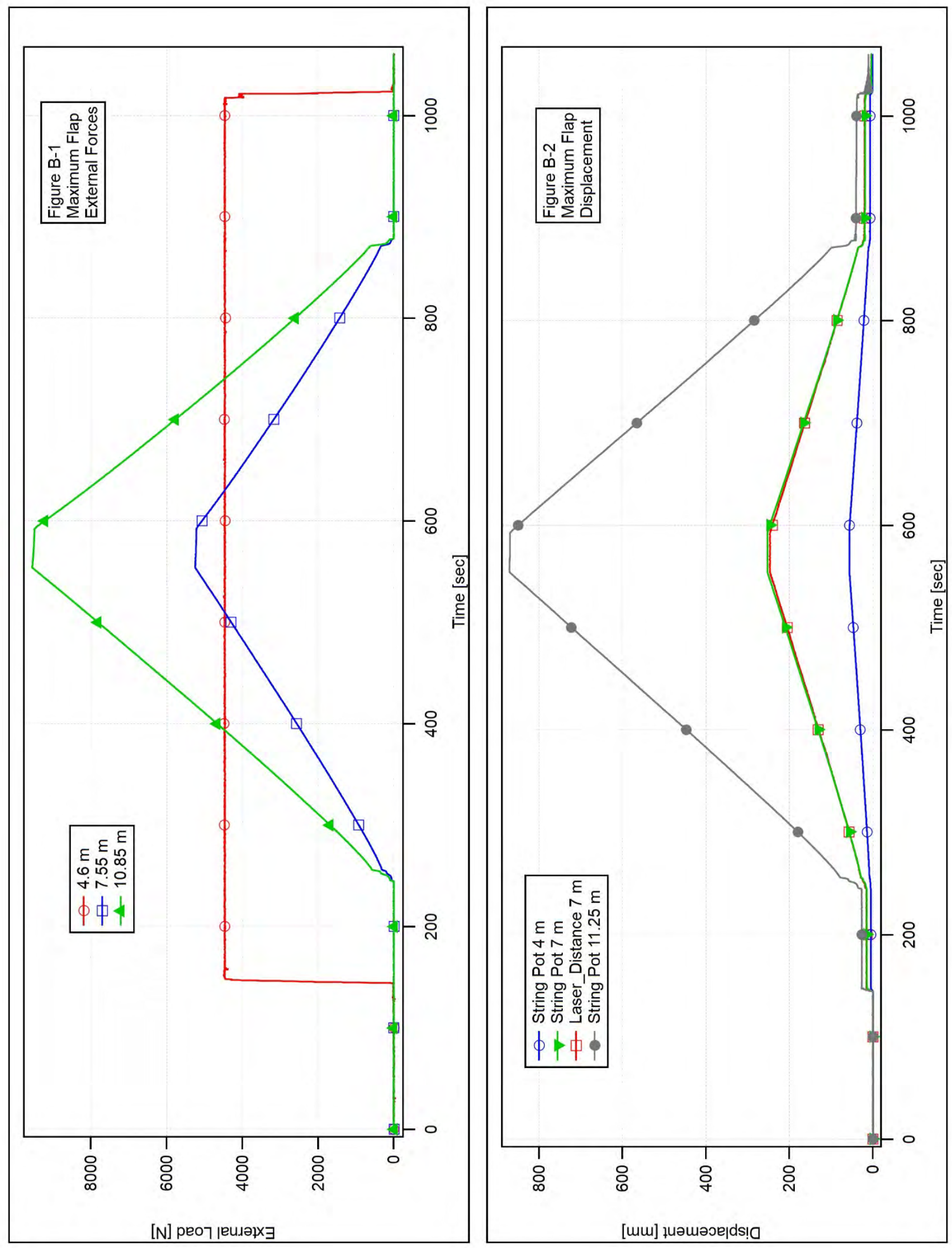

SNL_2017 - Sandia NRT Blade-0 Laboratory Structural Test Report

Page 33 of 85

This report is available at no cost from the National Renewable Energy Laboratory at www.nrel.gov/publications. 

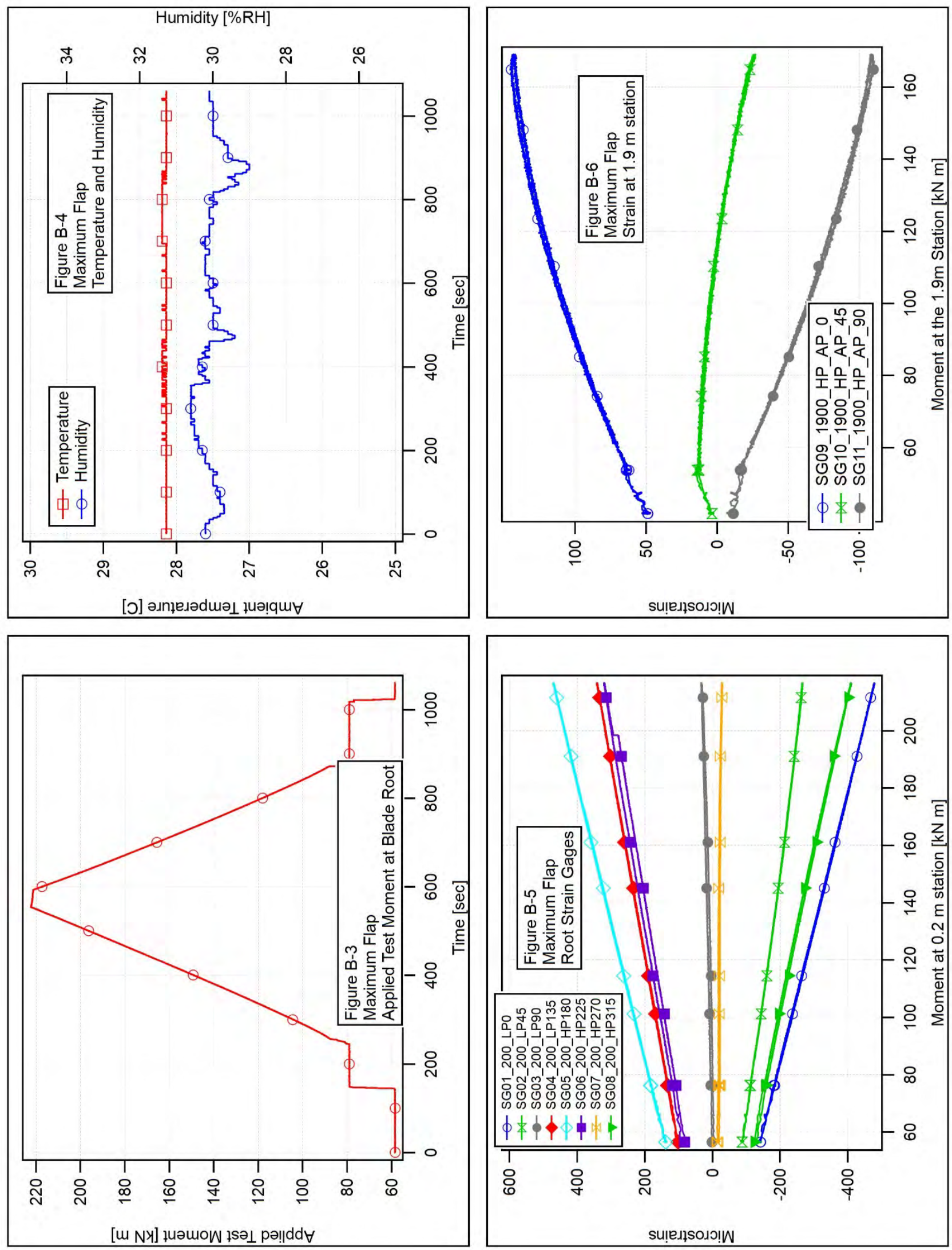

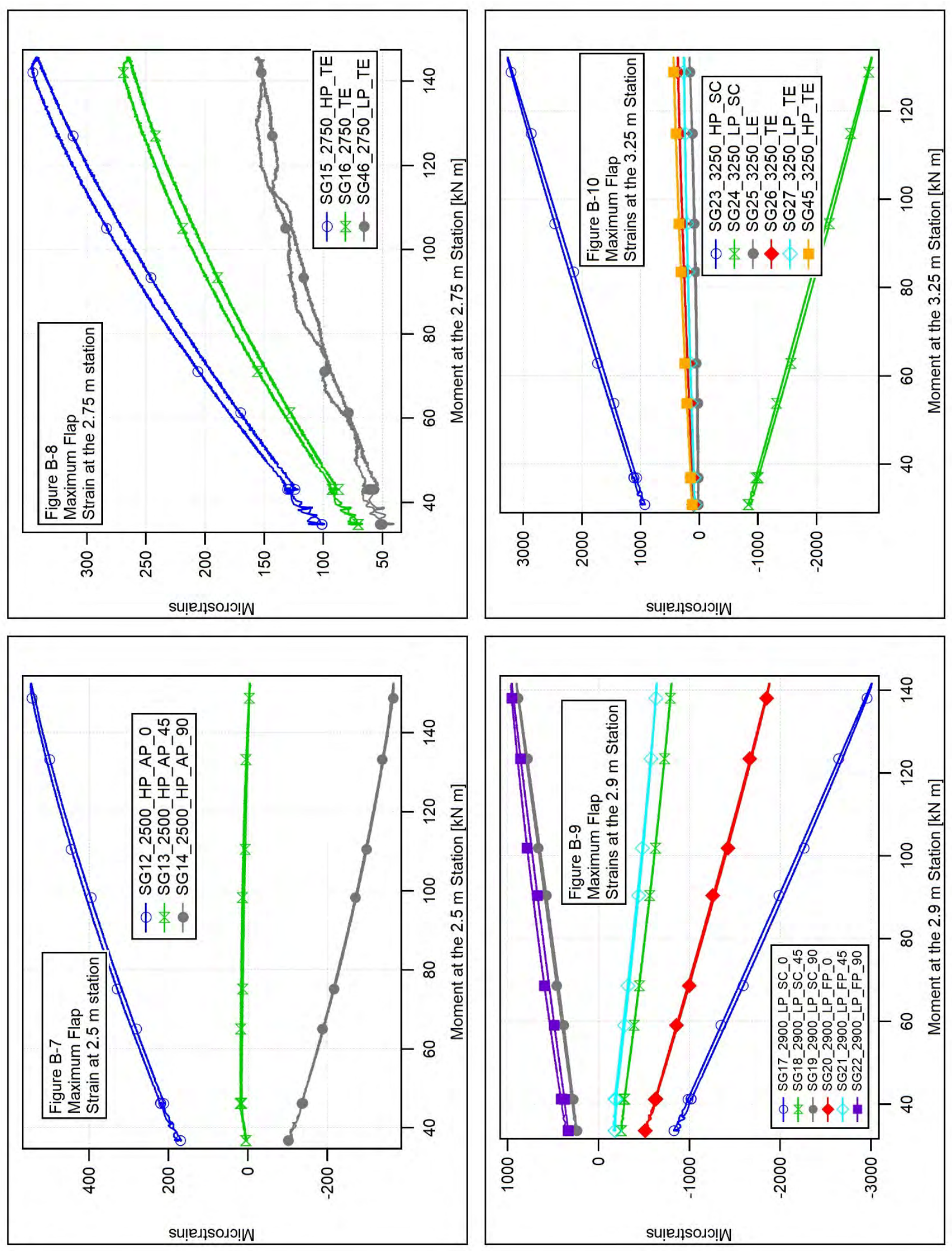

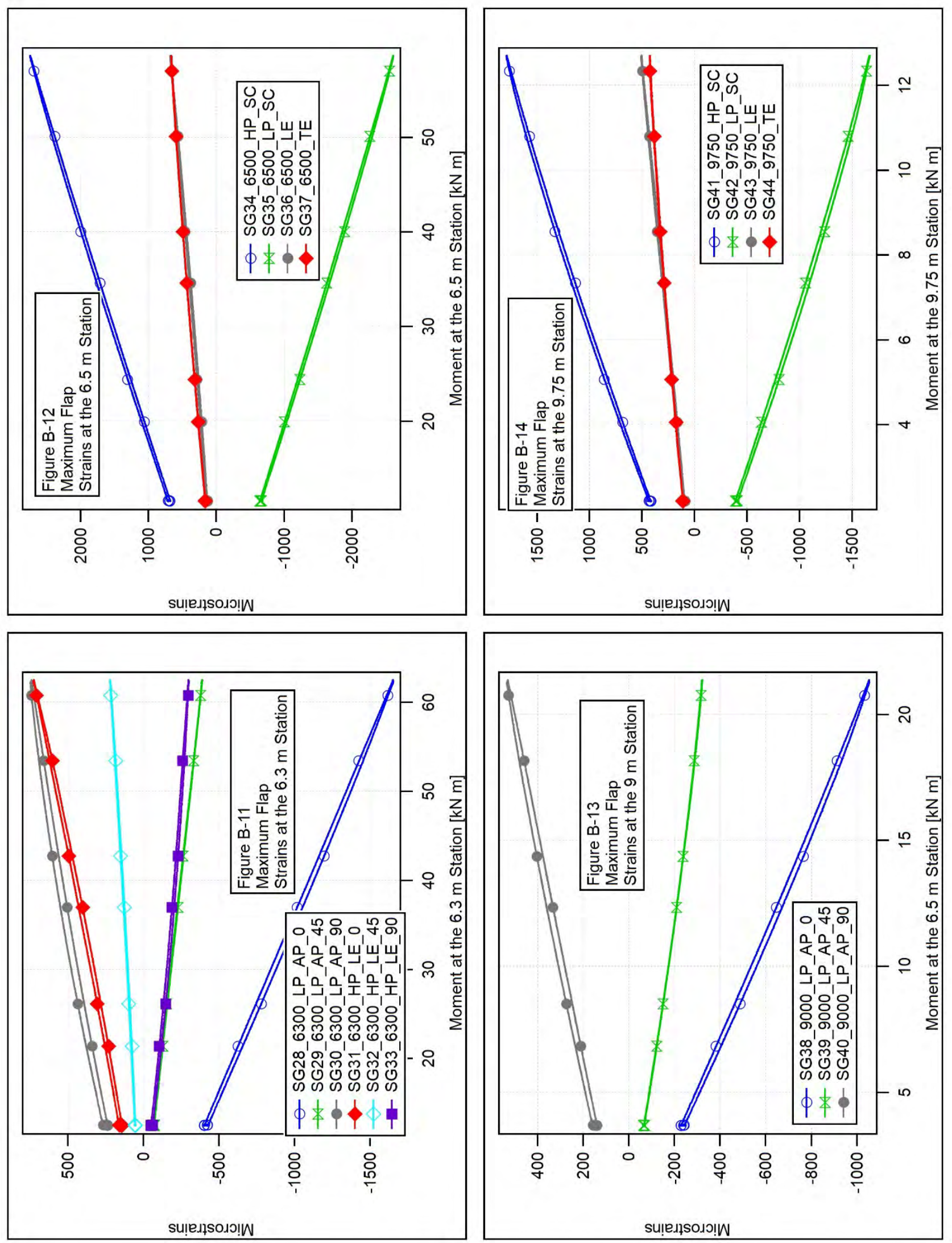

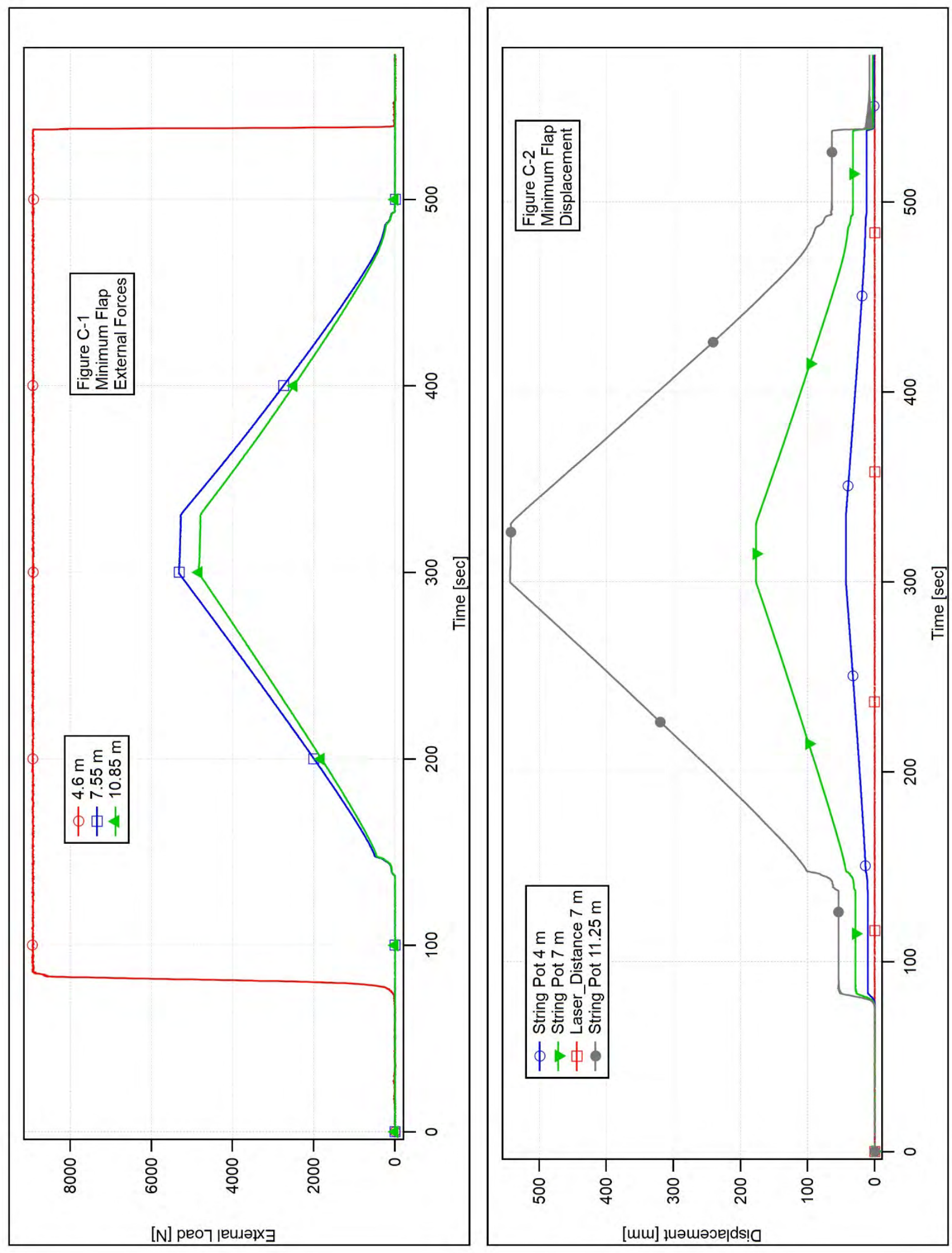

SNL_2017 - Sandia NRT Blade-0 Laboratory Structural Test Report

Page 37 of 85

This report is available at no cost from the National Renewable Energy Laboratory at www.nrel.gov/publications. 

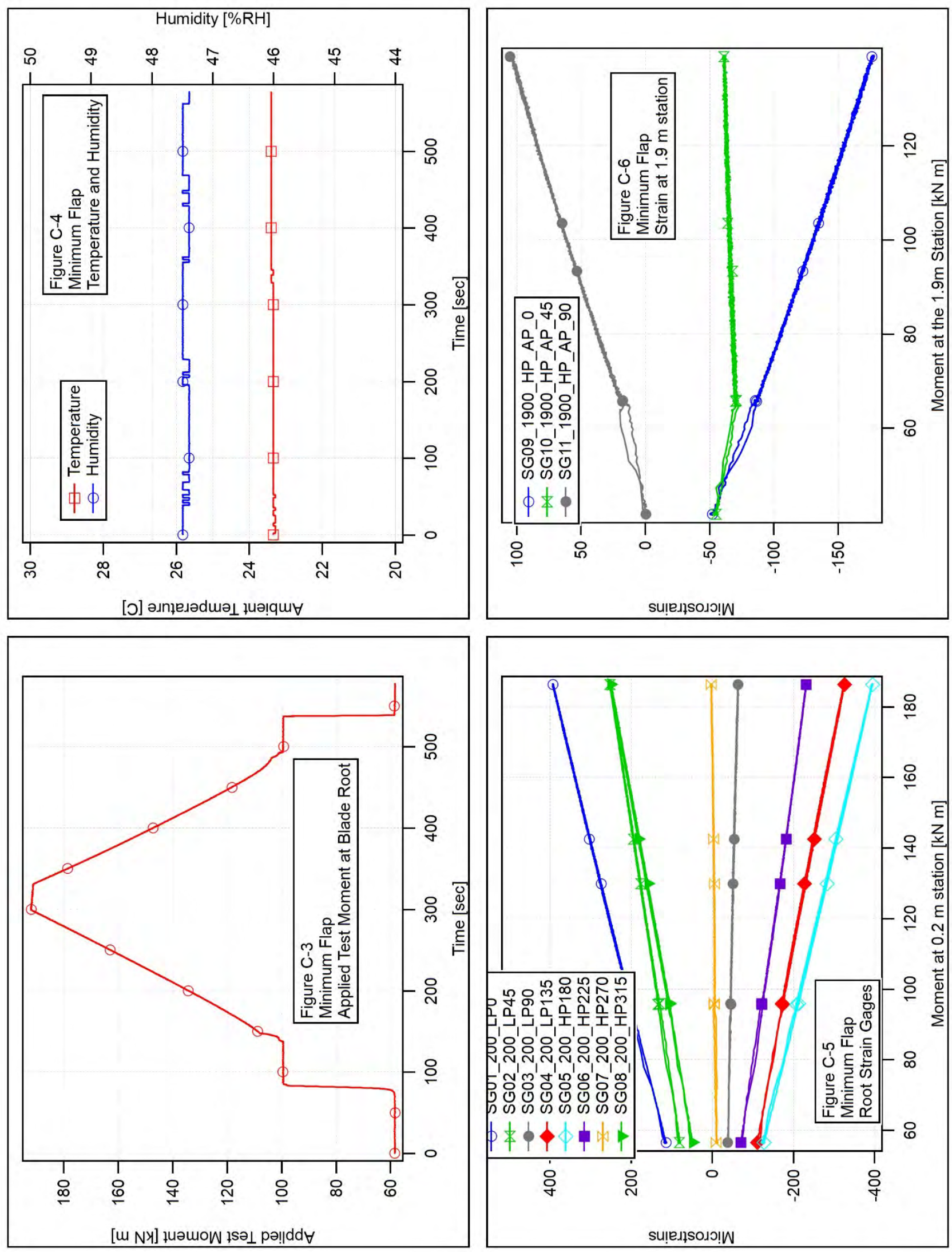

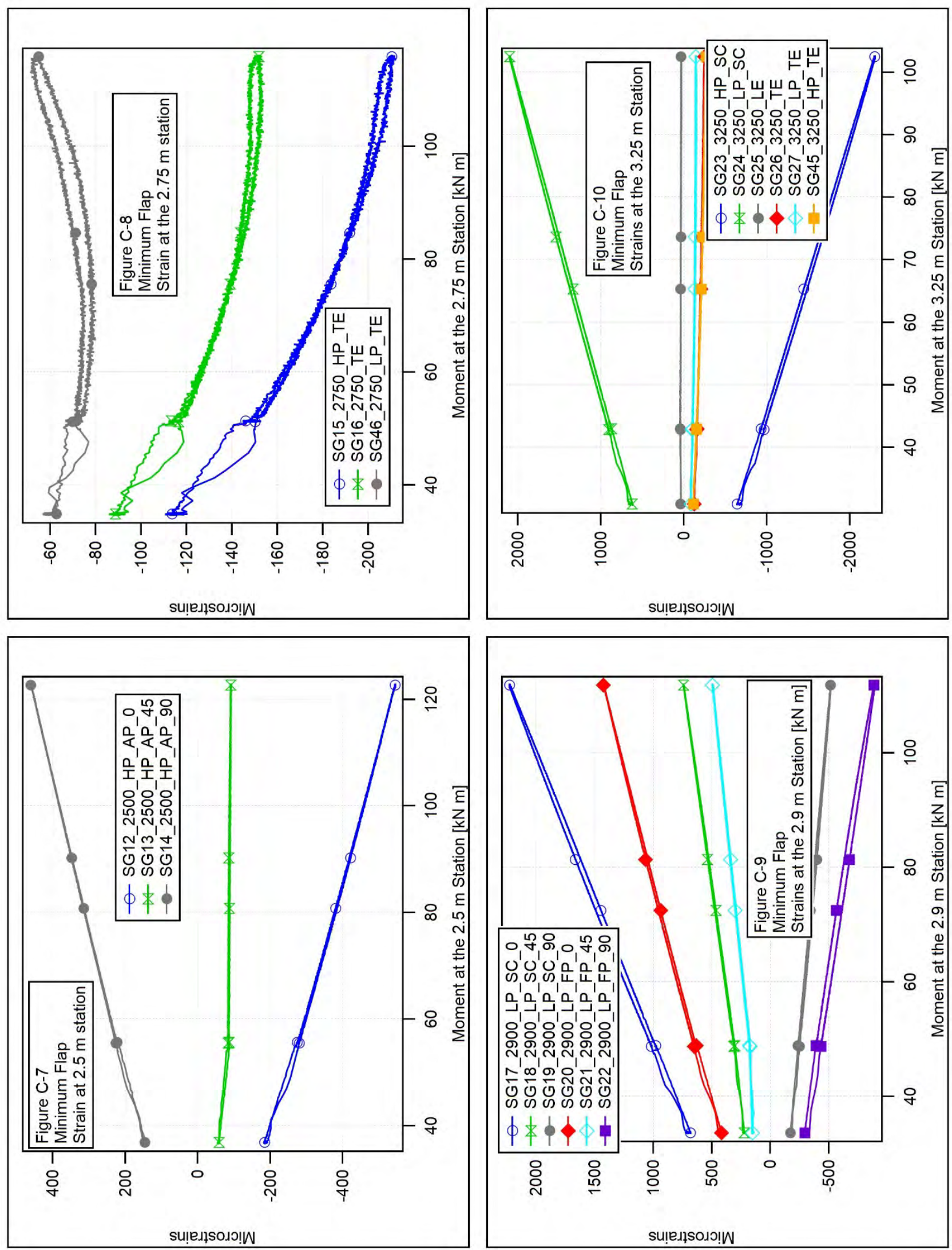

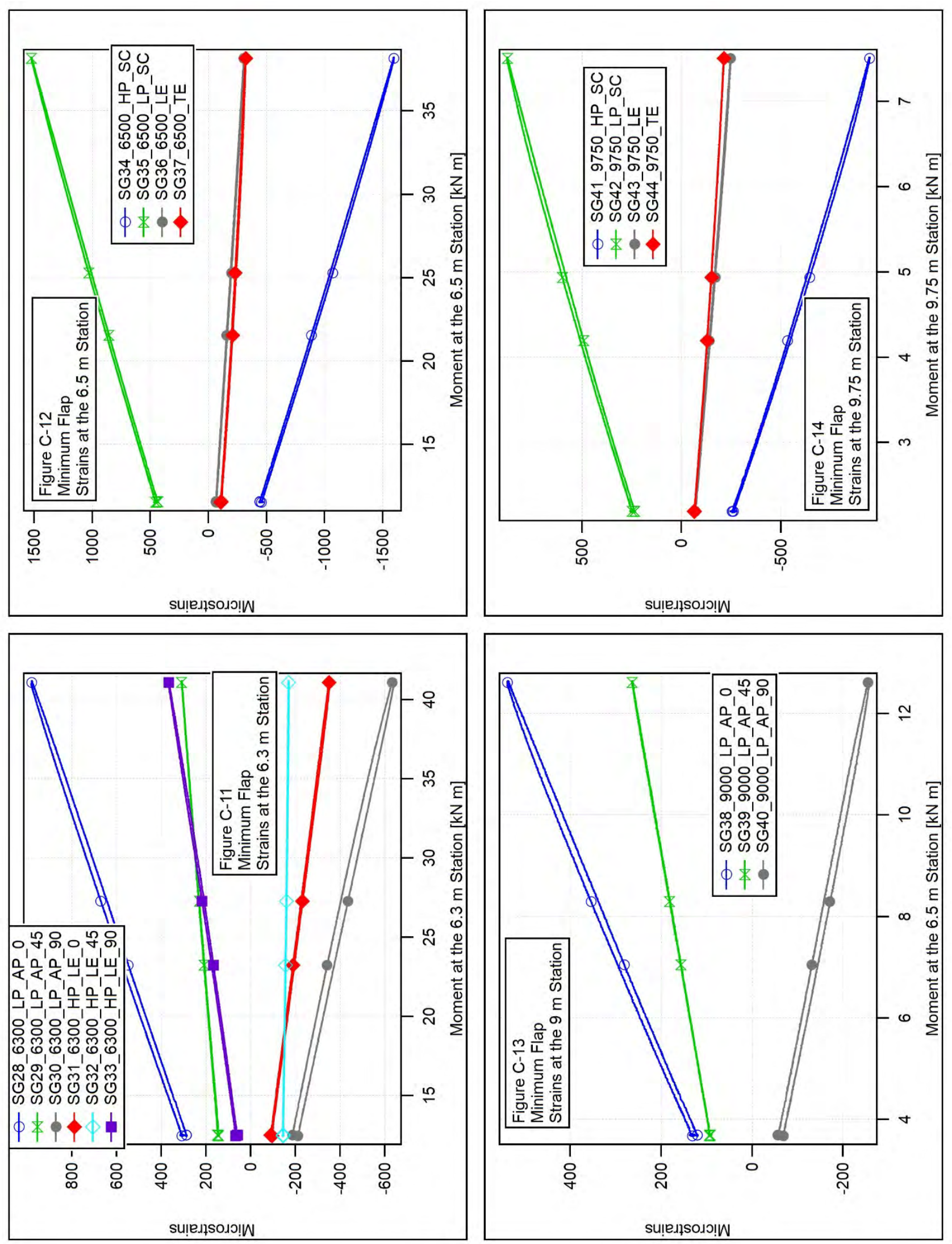

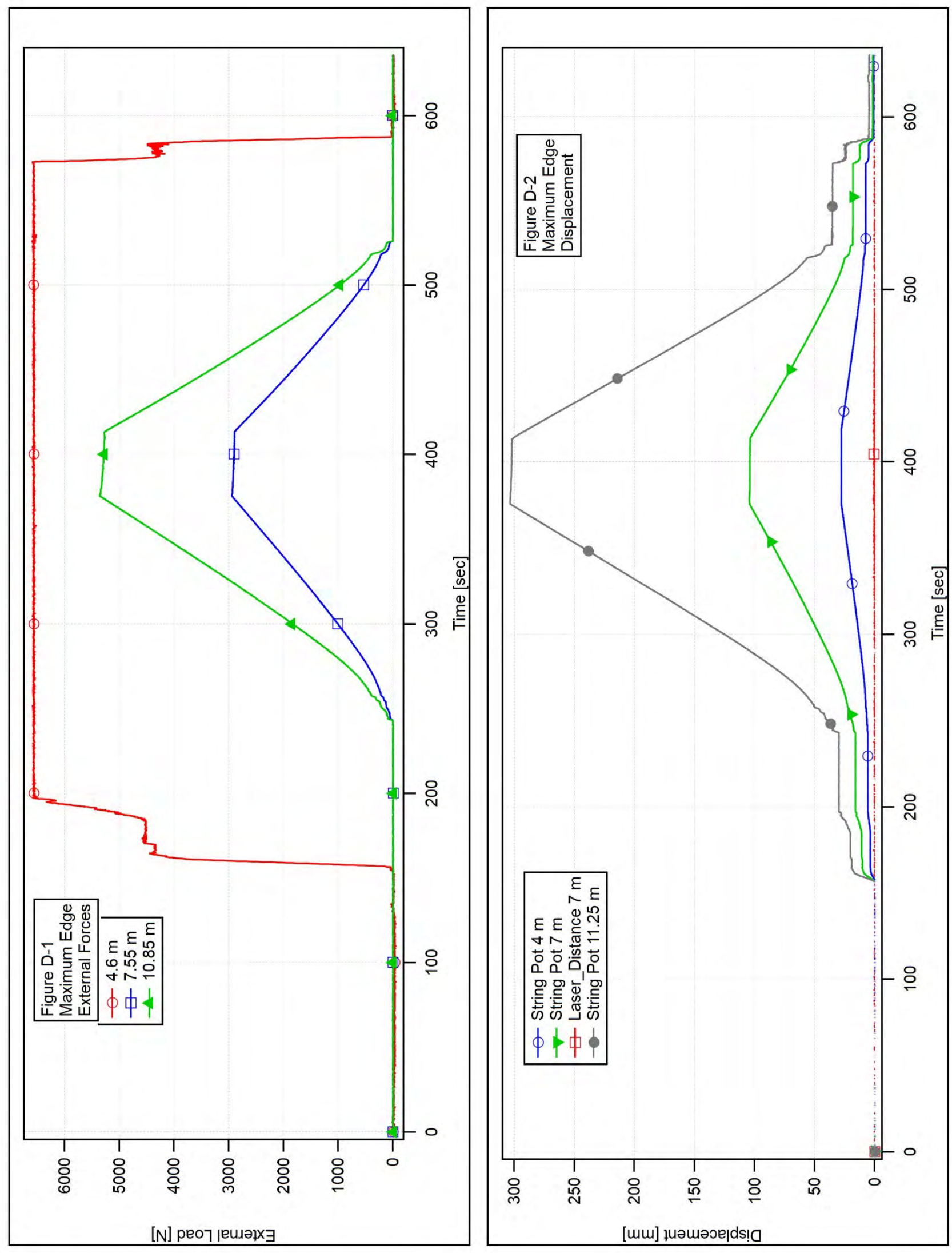

SNL_2017 - Sandia NRT Blade-0 Laboratory Structural Test Report

Page 41 of 85

This report is available at no cost from the National Renewable Energy Laboratory at www.nrel.gov/publications. 

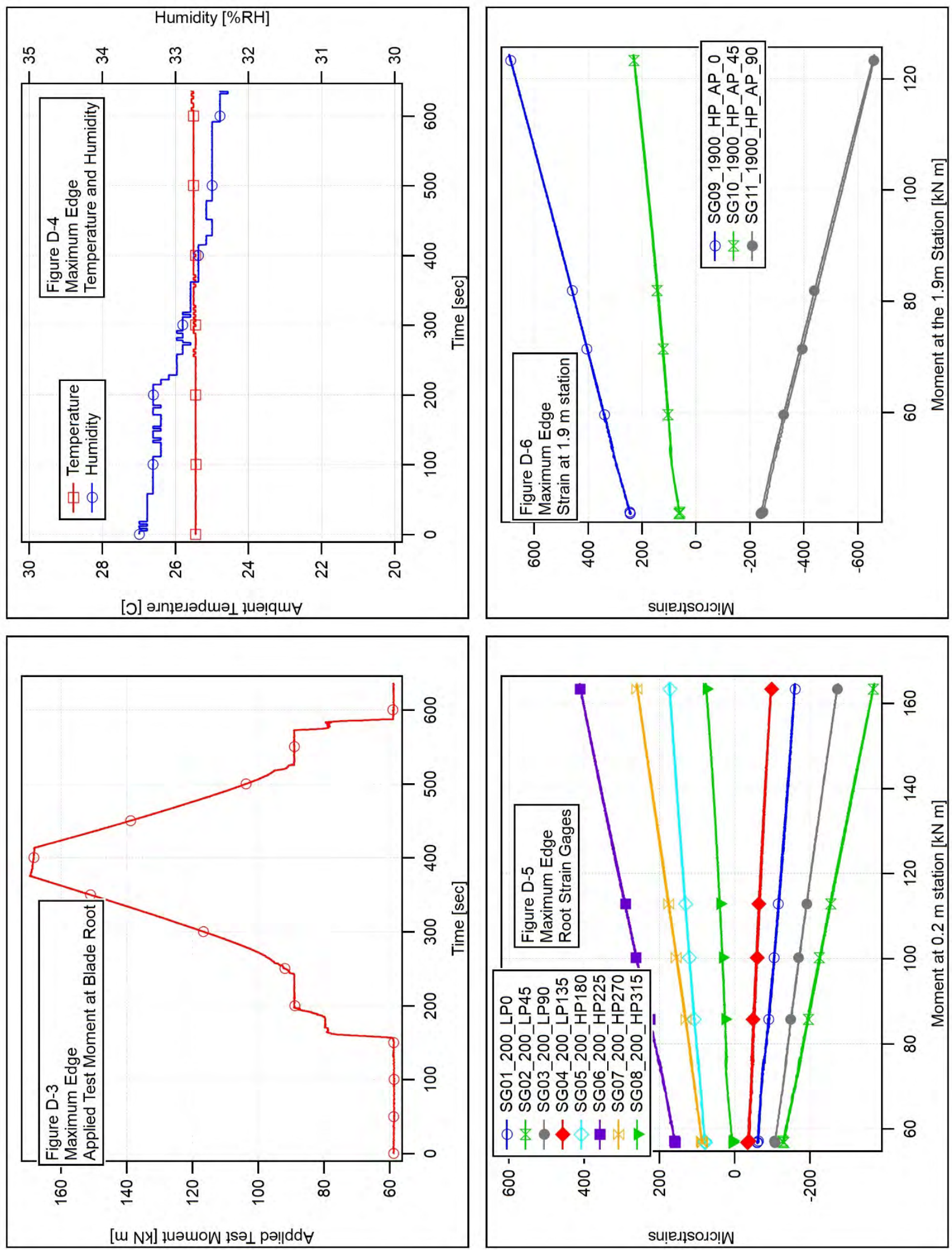

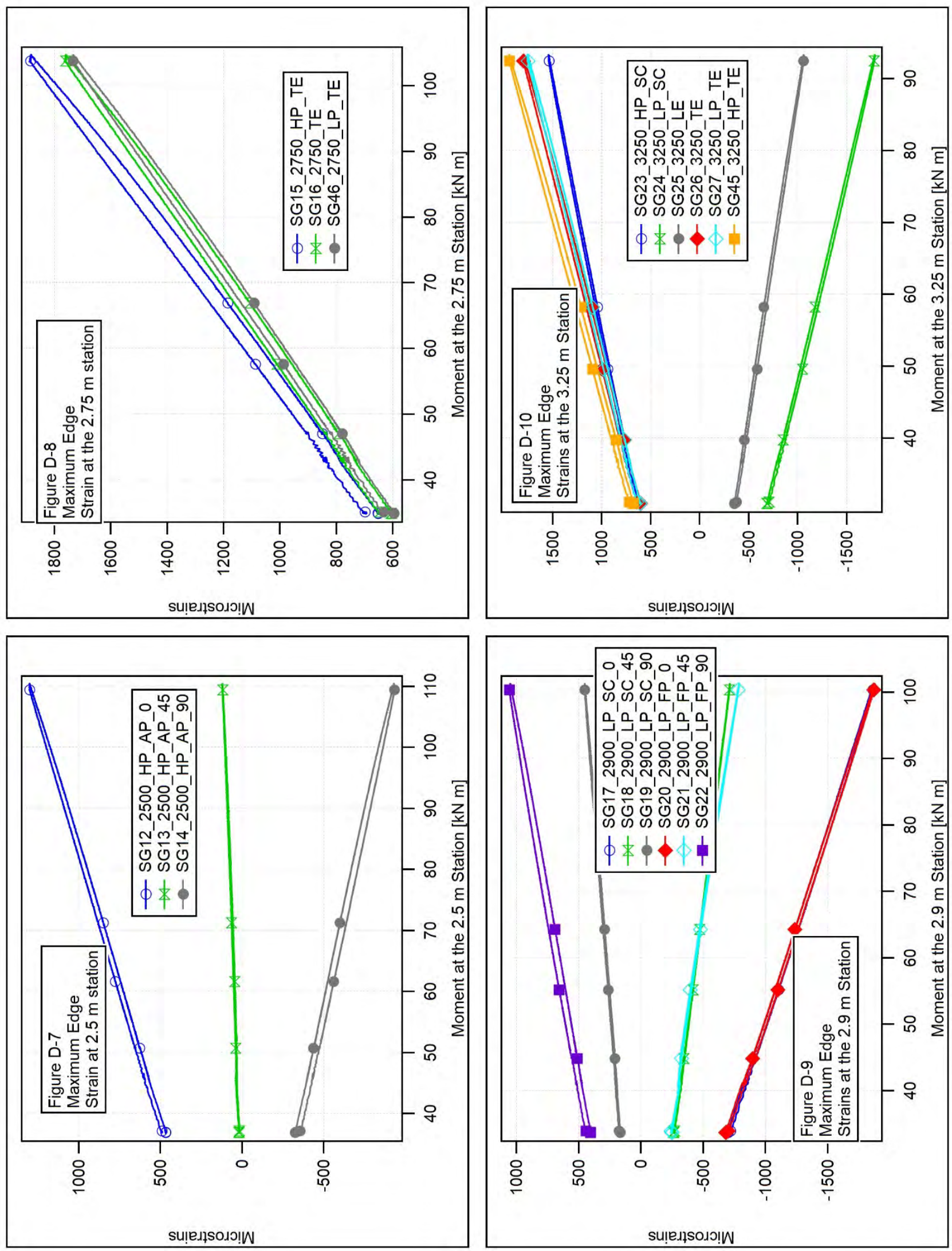

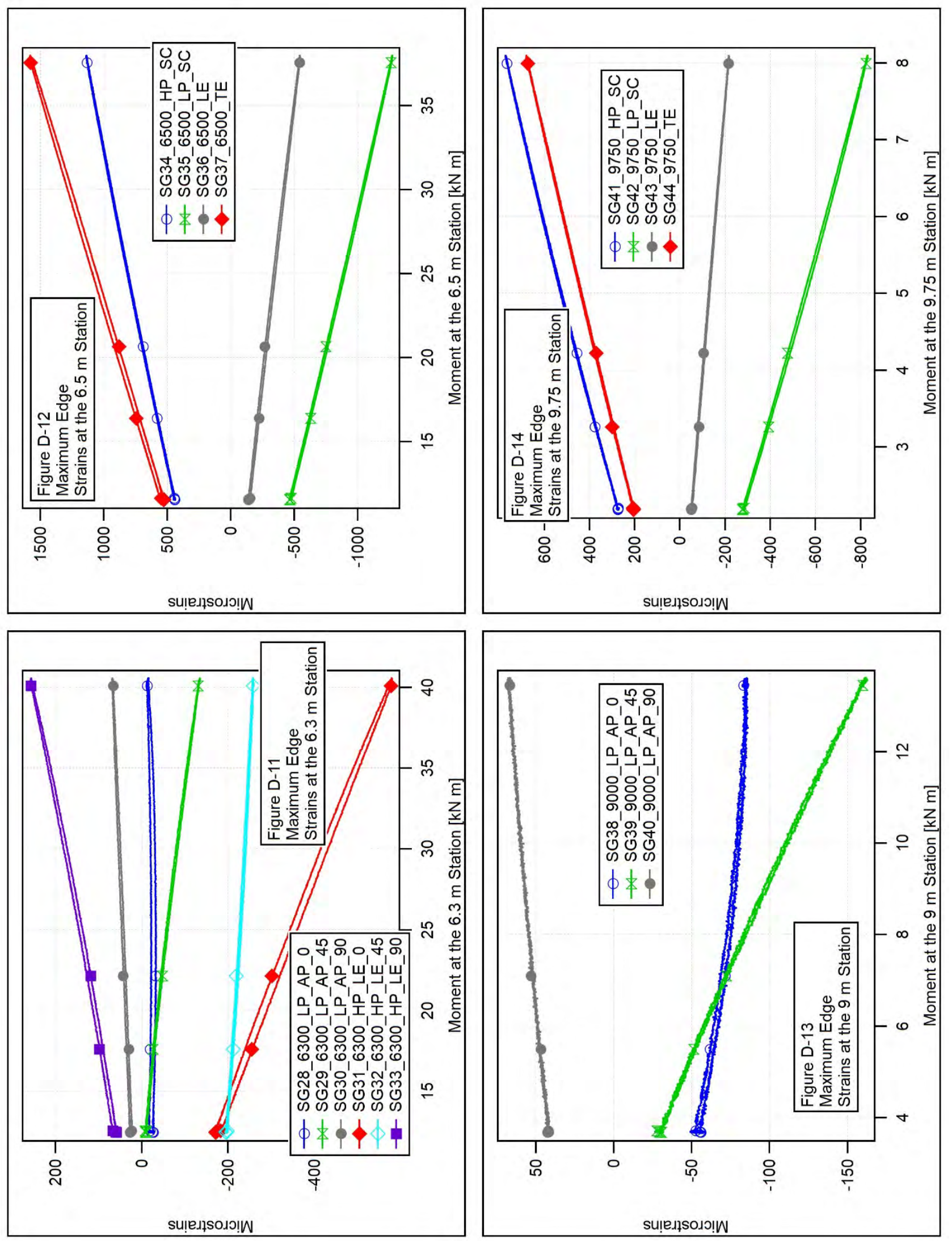


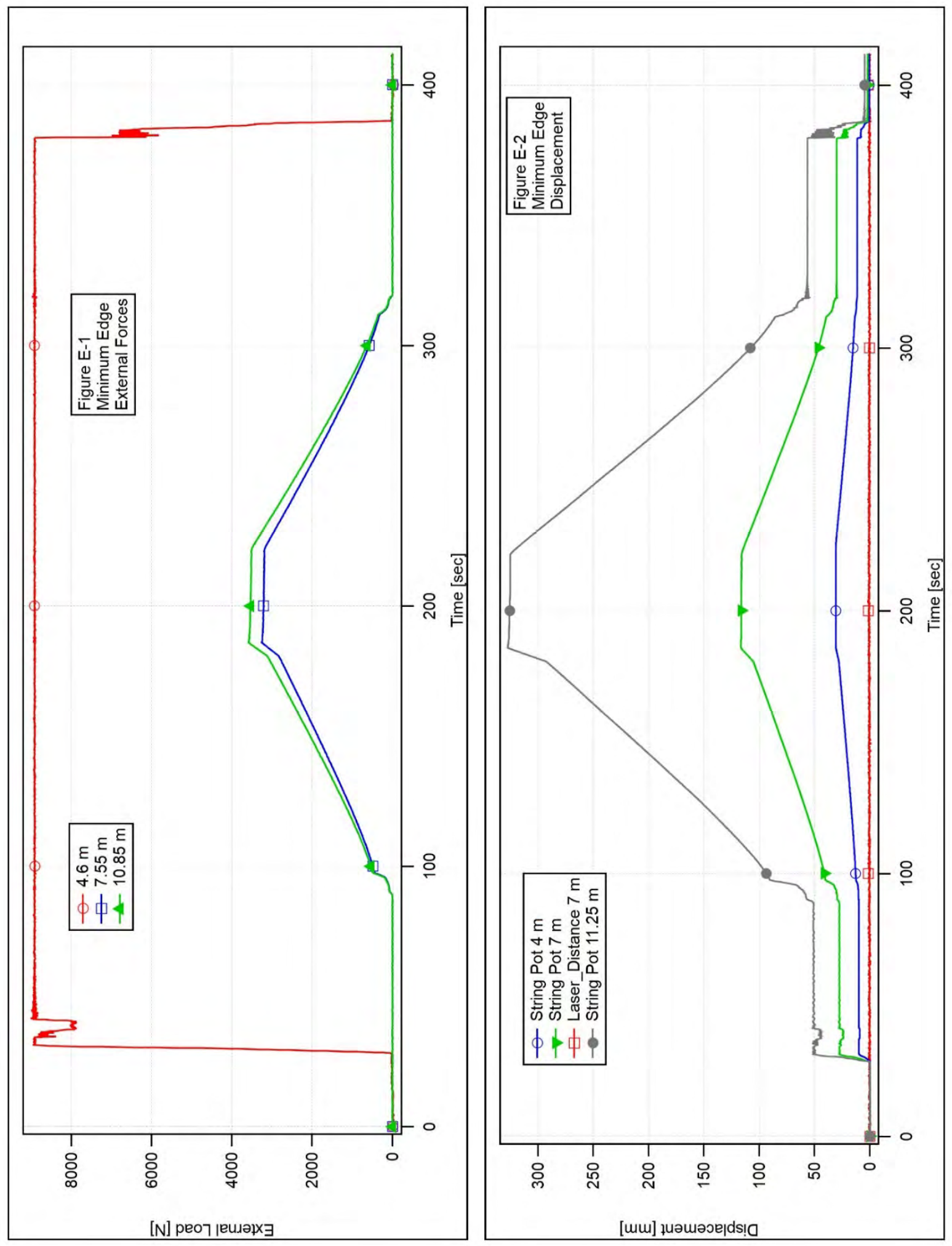



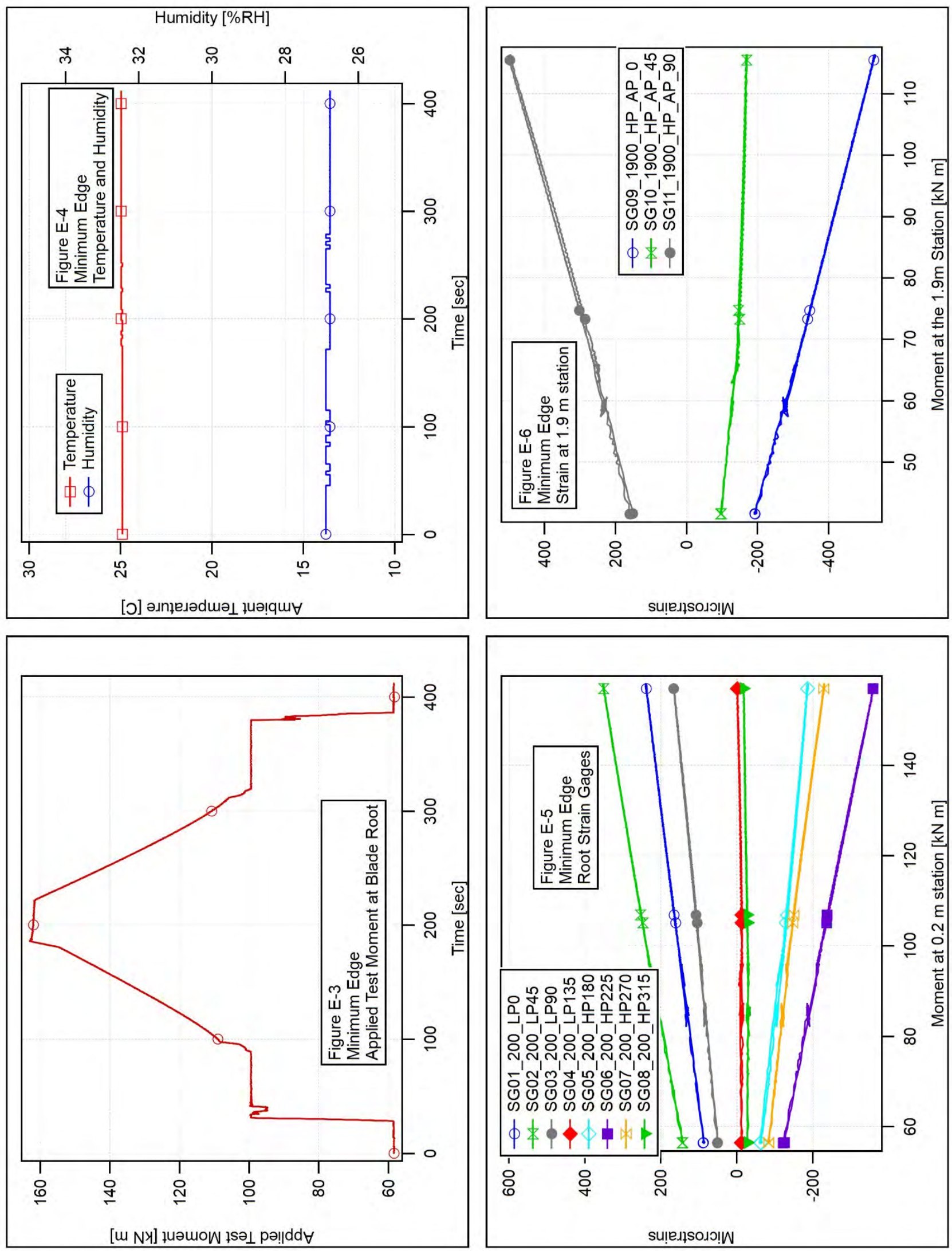

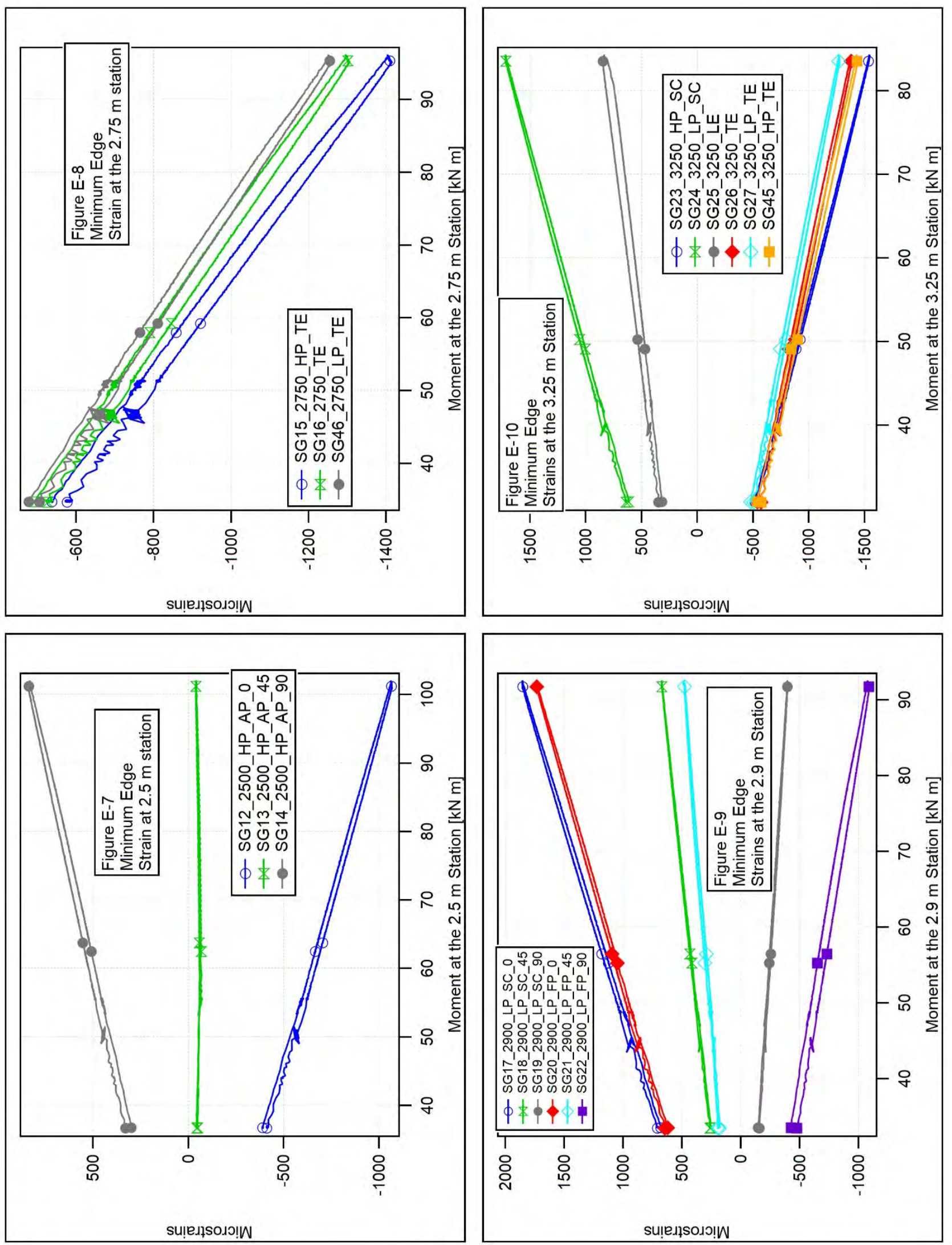

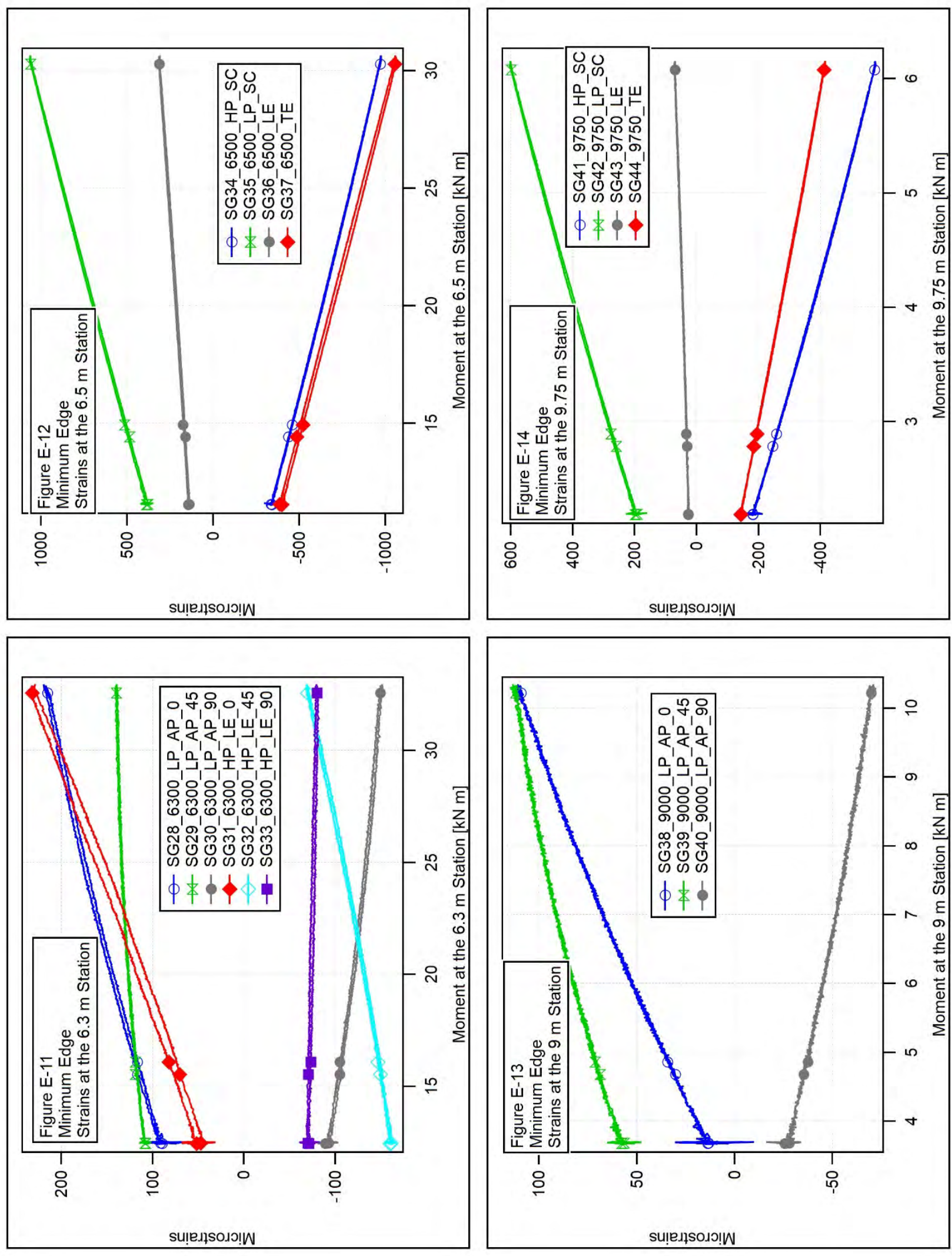


\section{APPENDIX F- Fatigue Damage Equivalent Load Calculation}

The equations used to estimate the damage equivalent load (DEL) are provided below. The DEL's were computed at five spanwise stations using the strain gages calibrated for bending moment. The DEL's are based on peak to peak strains and moments, mean effects were ignored. The equivalent damage was based on the target test cycles and target test bending moments. The complete peak-valley record of strains was used to estimate the DEL's. For reporting purposes, an inverse slope parameter $(\mathrm{m})$ of $\underline{10}$ was used.

$$
\begin{aligned}
& \text { Eq.1 } d_{i}=\left(\frac{M_{a}}{M_{u}}\right)^{m} * \frac{N_{a}}{N_{e q}} \\
& \text { Eq.2 } D=\sum d_{i} \\
& \text { Eq.3 DEL }=M_{u} * D^{\frac{1}{m}}
\end{aligned}
$$

Definitions for the variables in Equations 1 through 3 include:

- di - damage from binned moment range

- D - damage from all binned moment ranges

- Ma - binned moment range

- $\mathrm{Mu}$ - target test moment range

- $\mathrm{Na}$ - number of cycles in a bin

- $\mathrm{Neq}$ - damage equivalent cycles ( $\mathrm{Neq}=1 \mathrm{e} 6$ used in this analysis)

- $\mathrm{M}$ - inverse slope parameter ( $\mathrm{m}=10$ used in this analysis) 

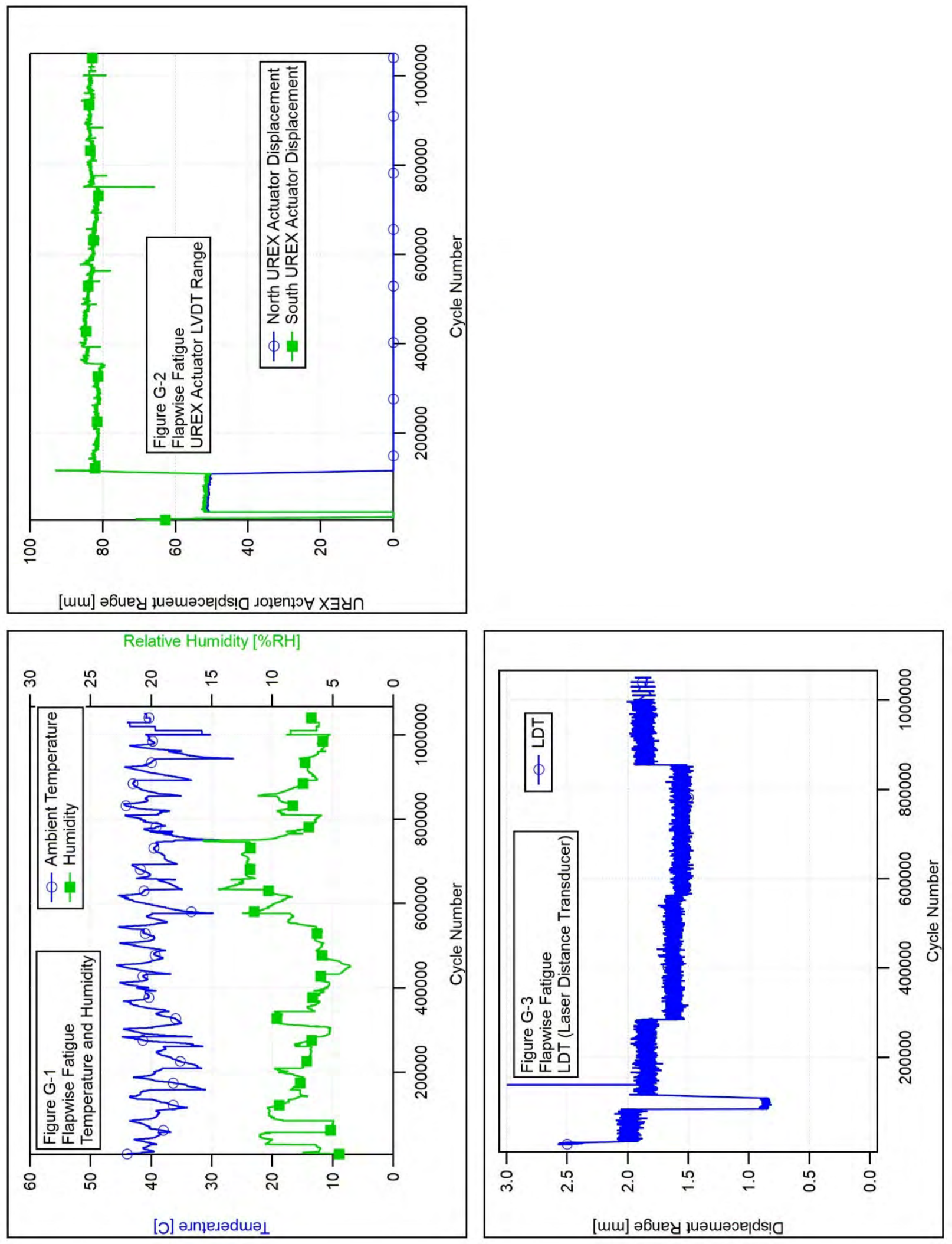

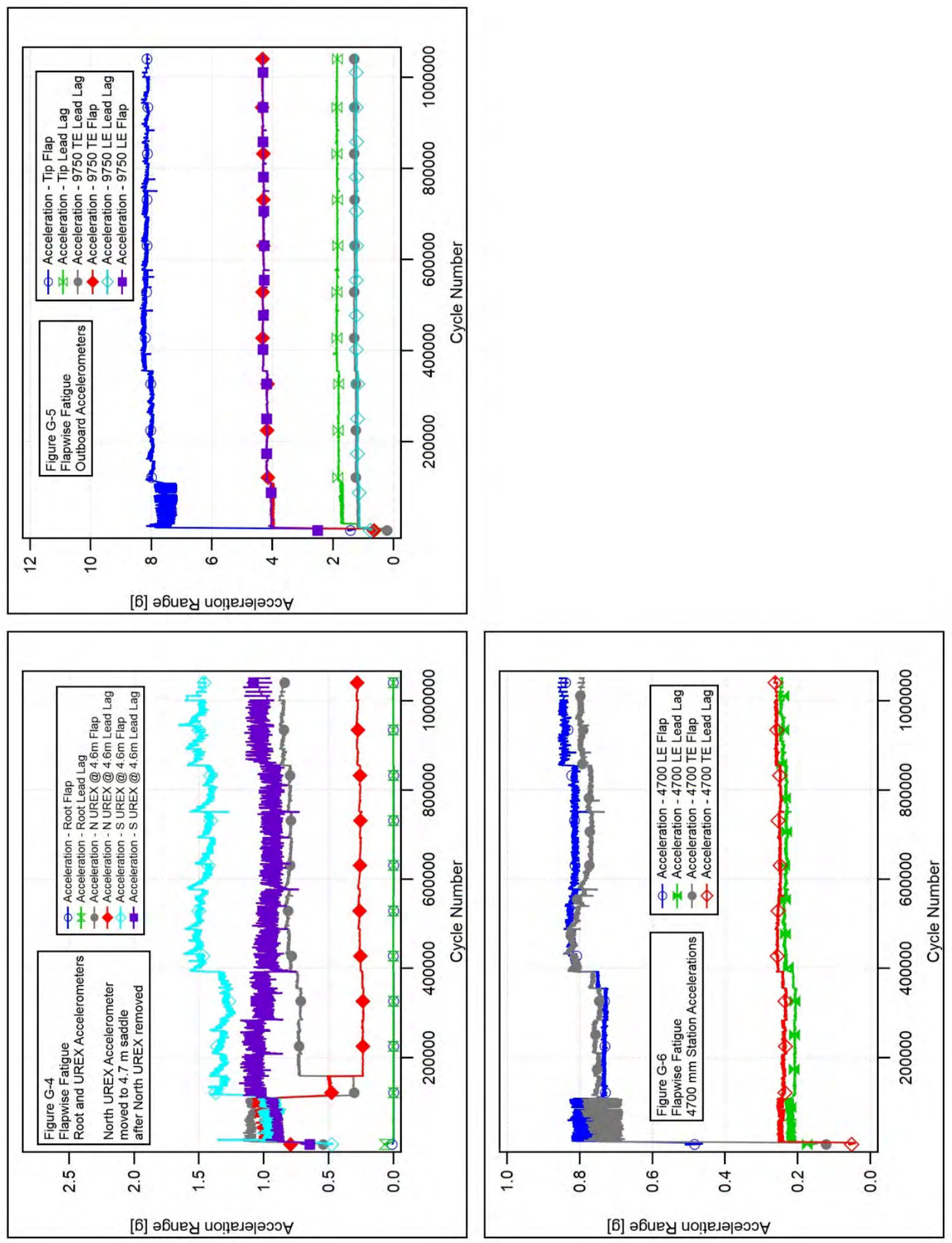

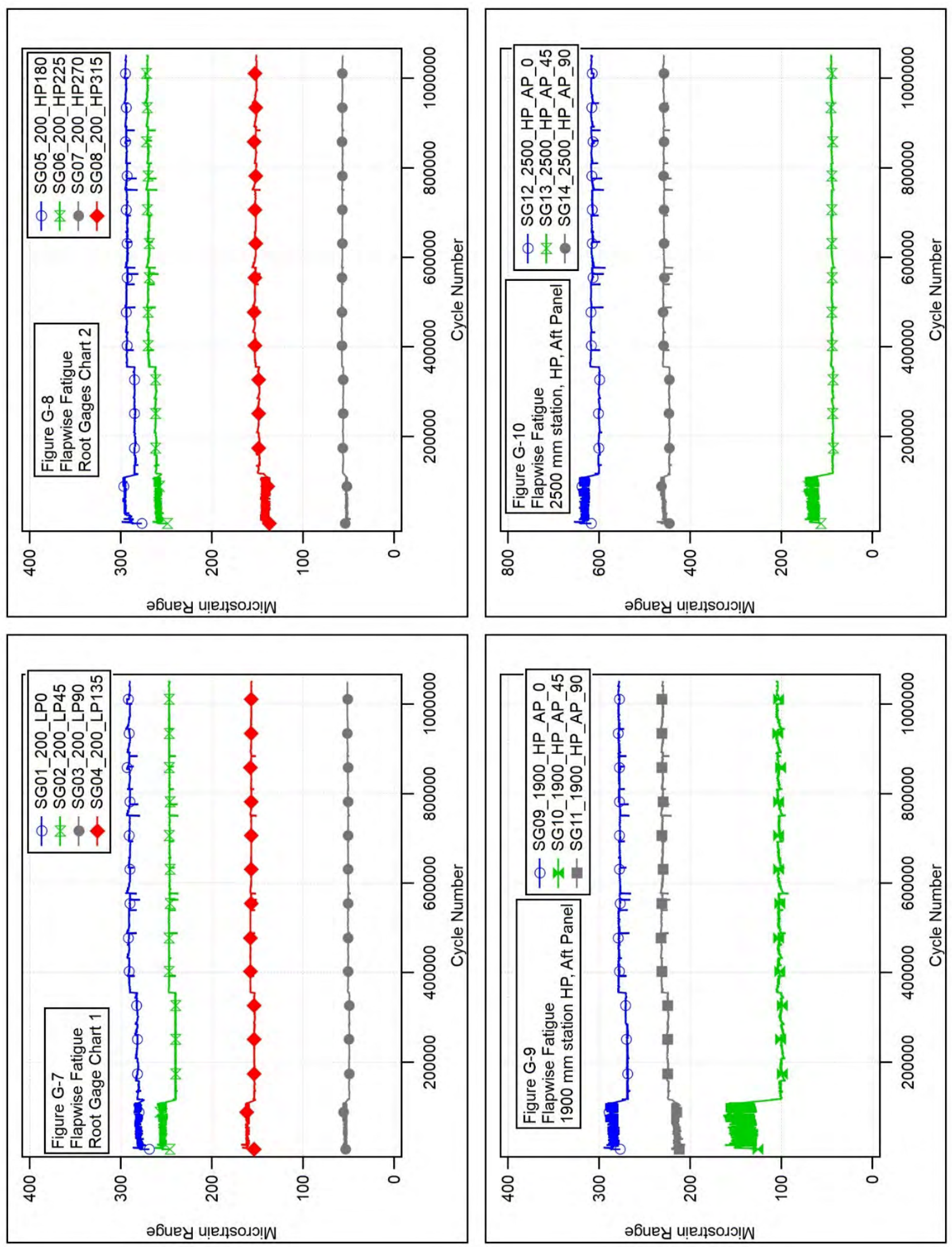

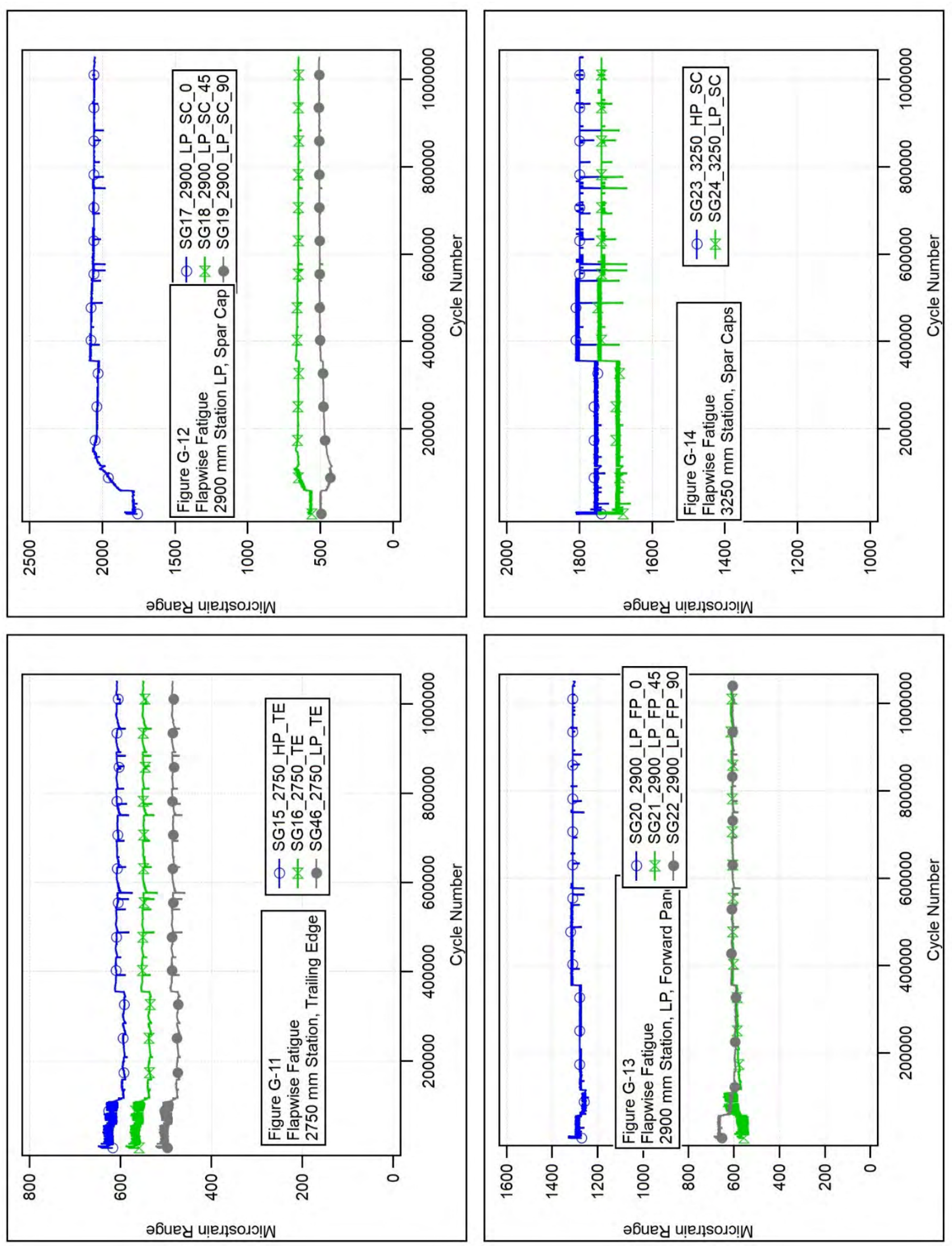

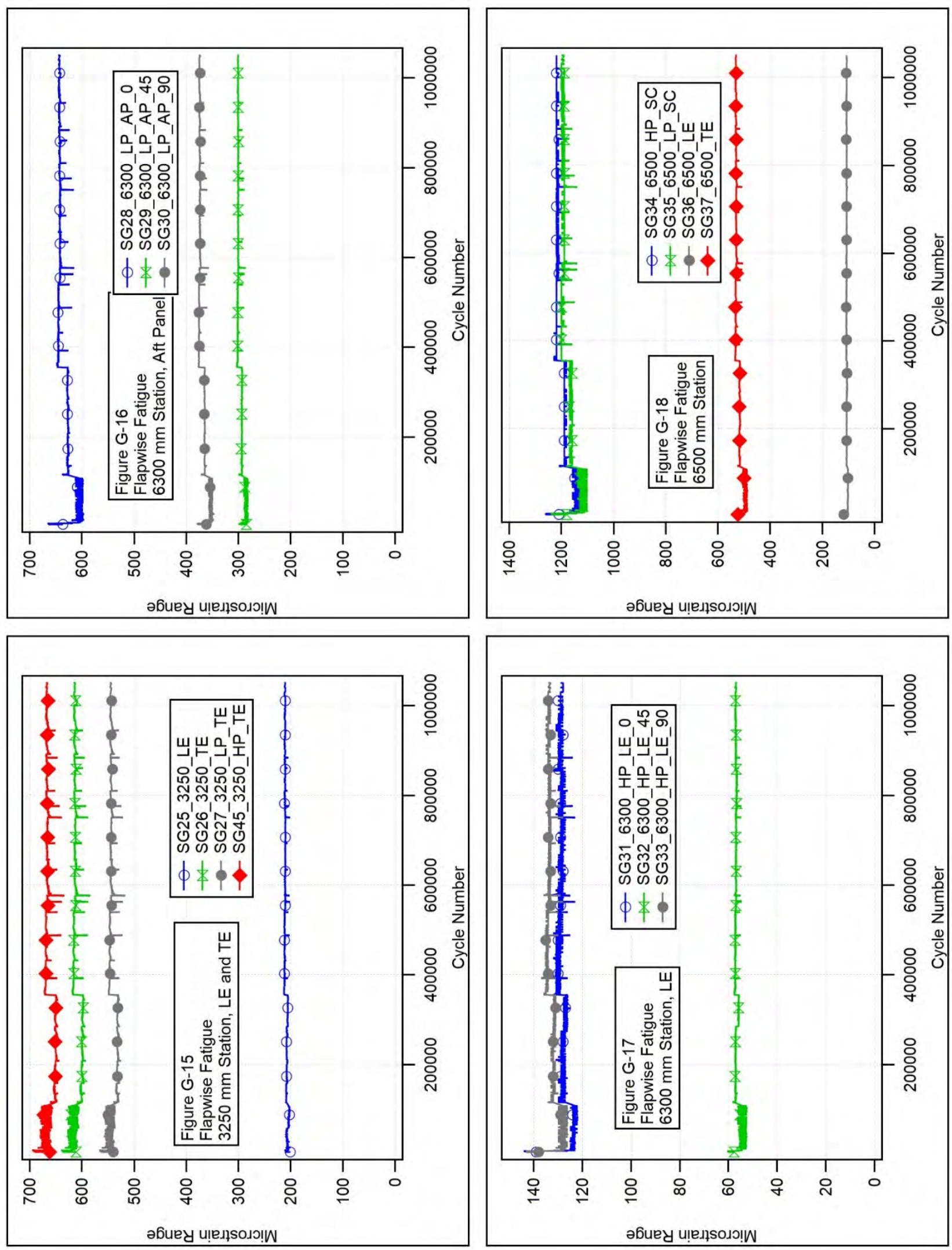

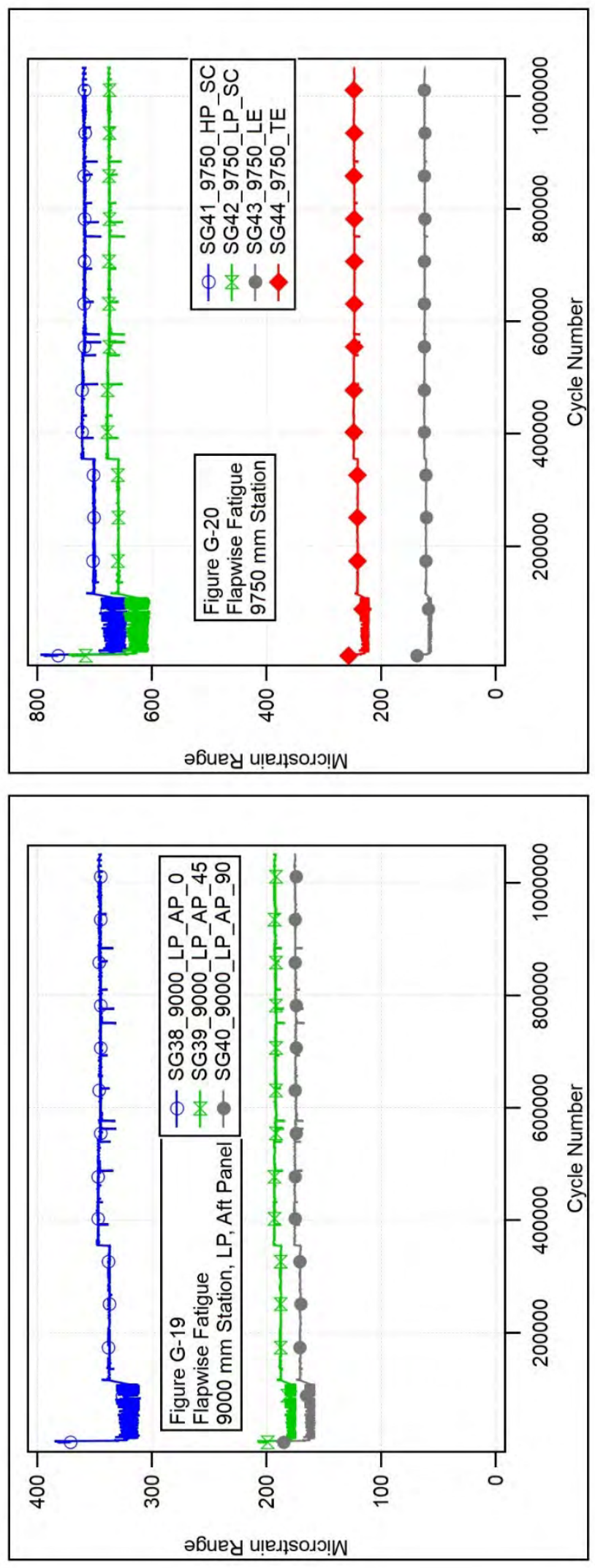

SNL_2017 - Sandia NRT Blade-0 Laboratory Structural Test Report

Page 55 of 85

This report is available at no cost from the National Renewable Energy Laboratory at www.nrel.gov/publications. 


\section{APPENDIX H - Ultimate Flap Charts}

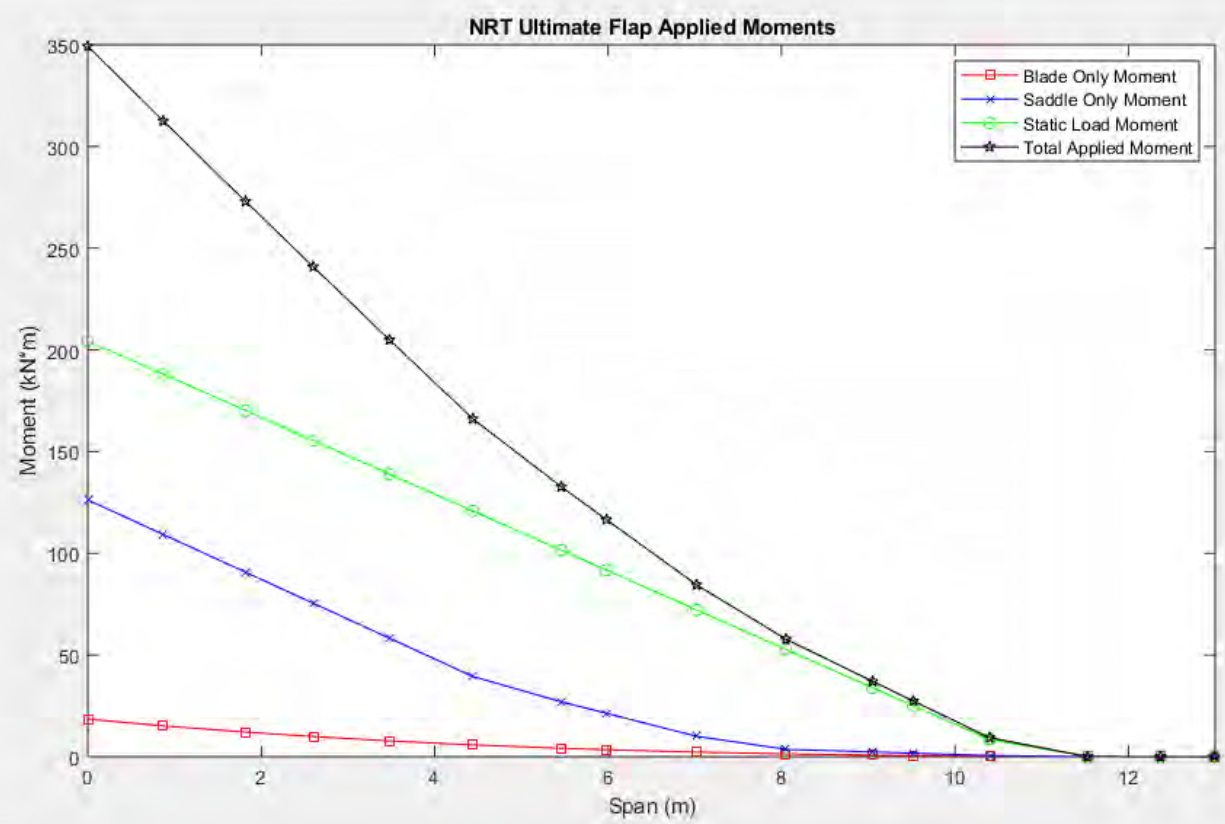

\section{Figure $\mathrm{H}-1$}

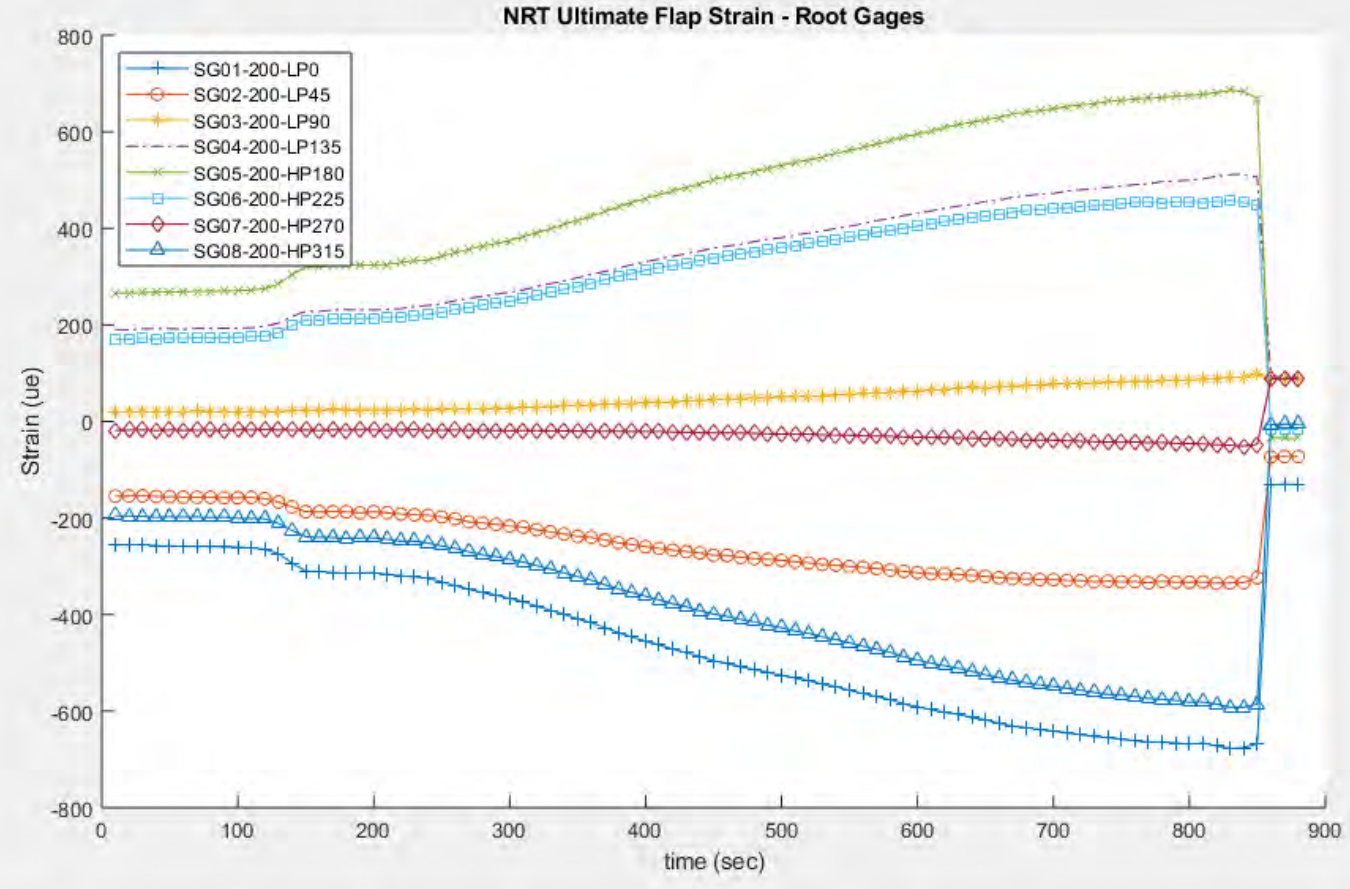

Figure $\mathrm{H}-2$ 


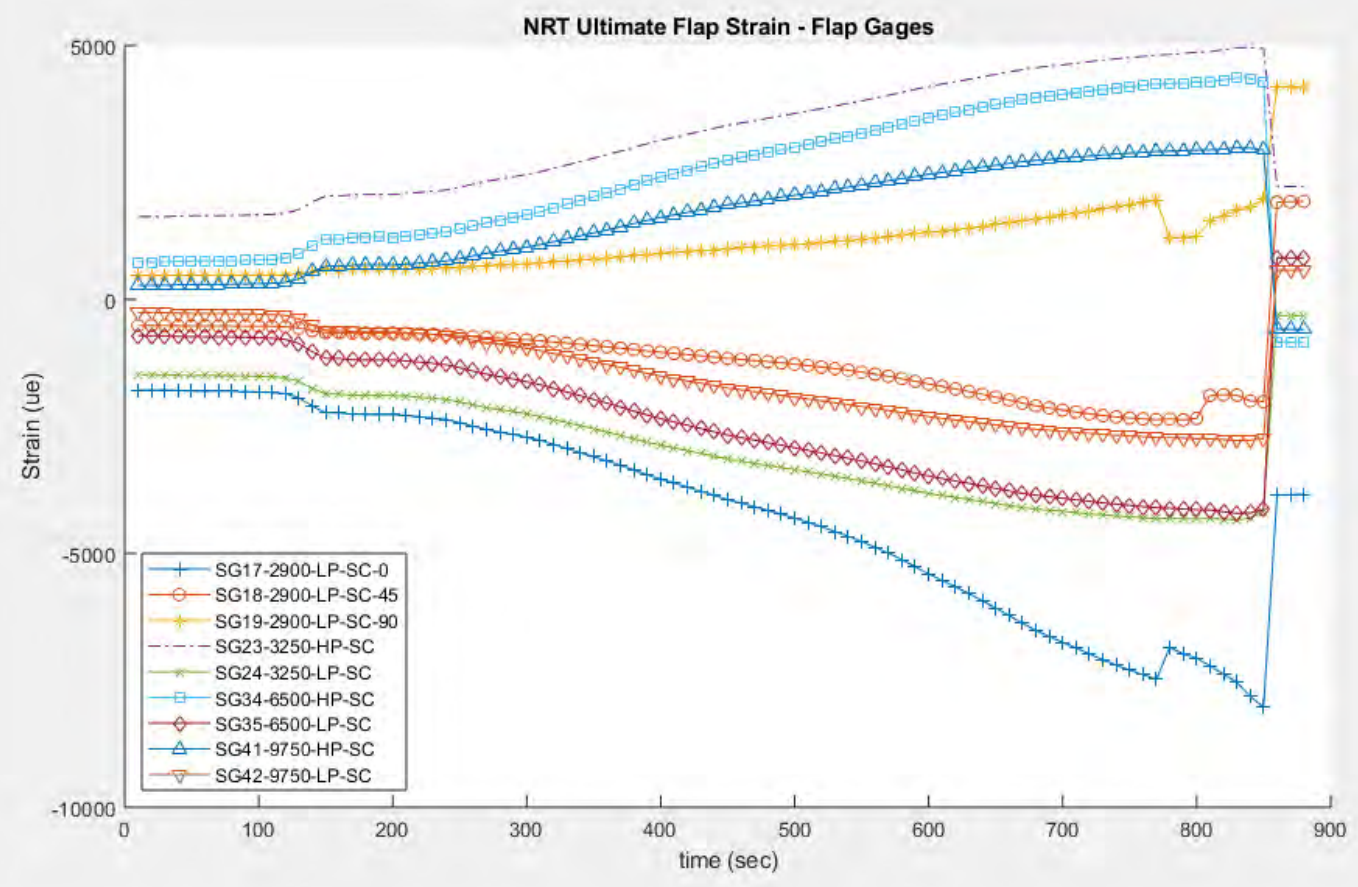

\section{Figure $\mathrm{H}-3$}

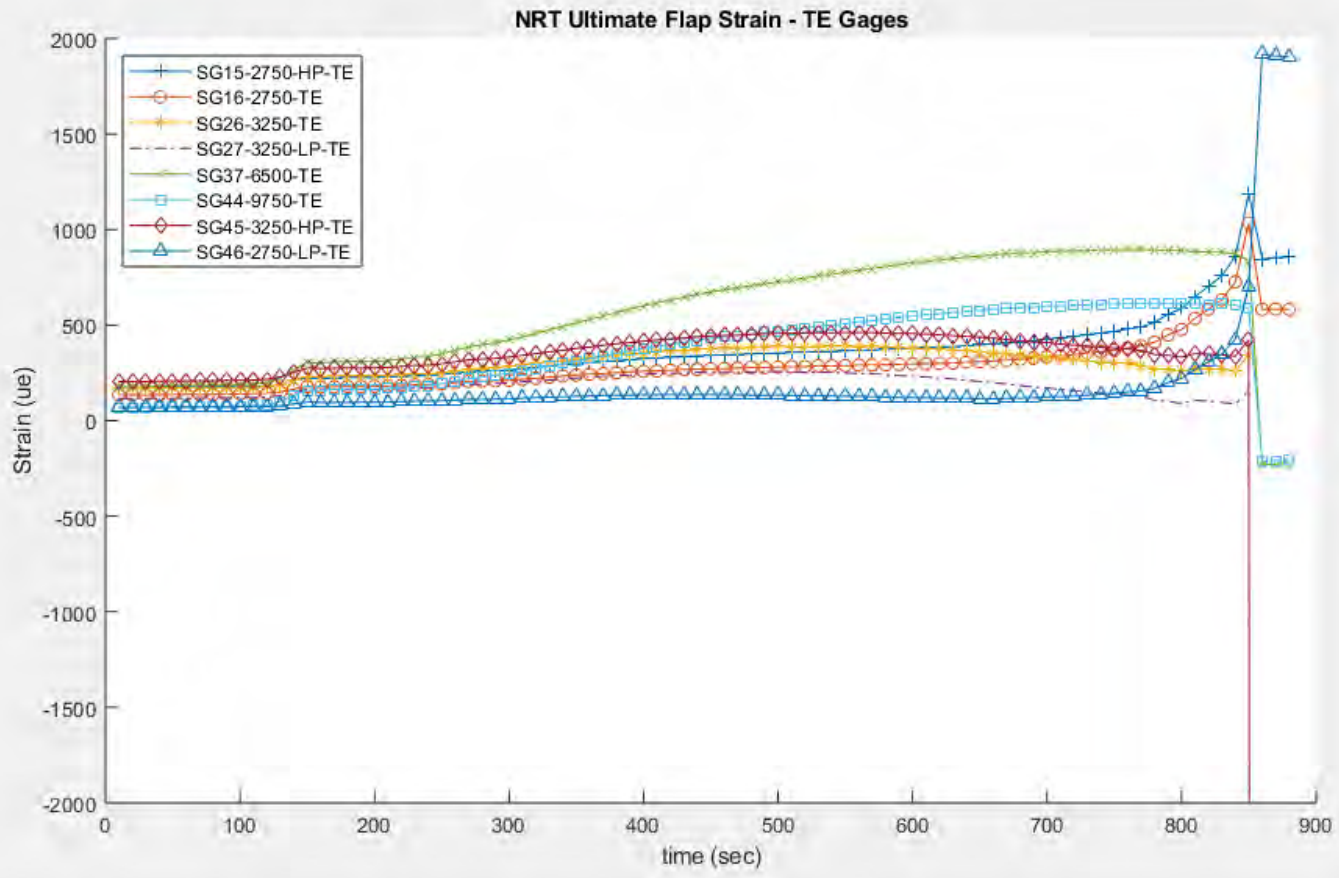

Figure $\mathrm{H}-4$ 


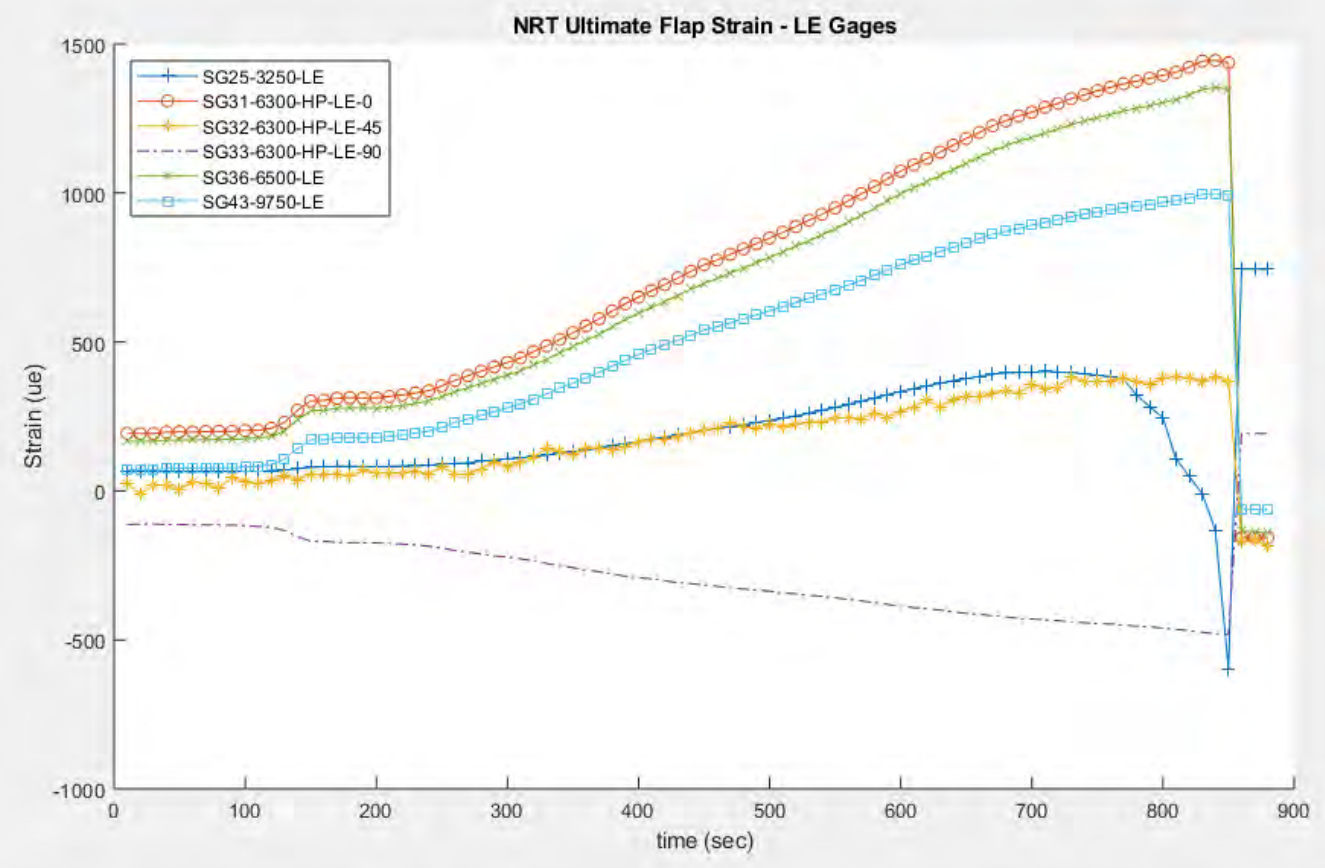

\section{Figure $\mathrm{H}-5$}

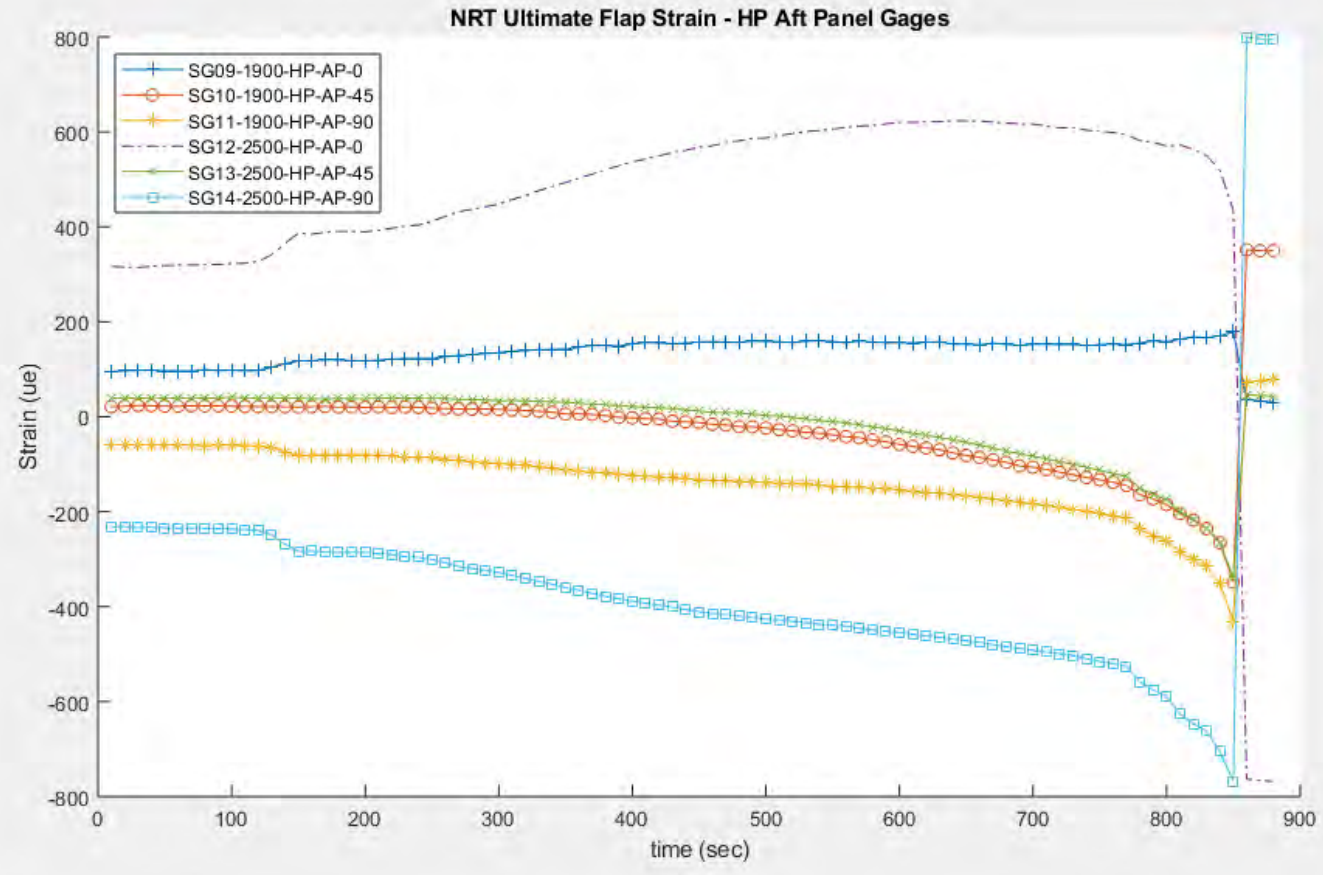

\section{Figure $\mathrm{H}-6$}




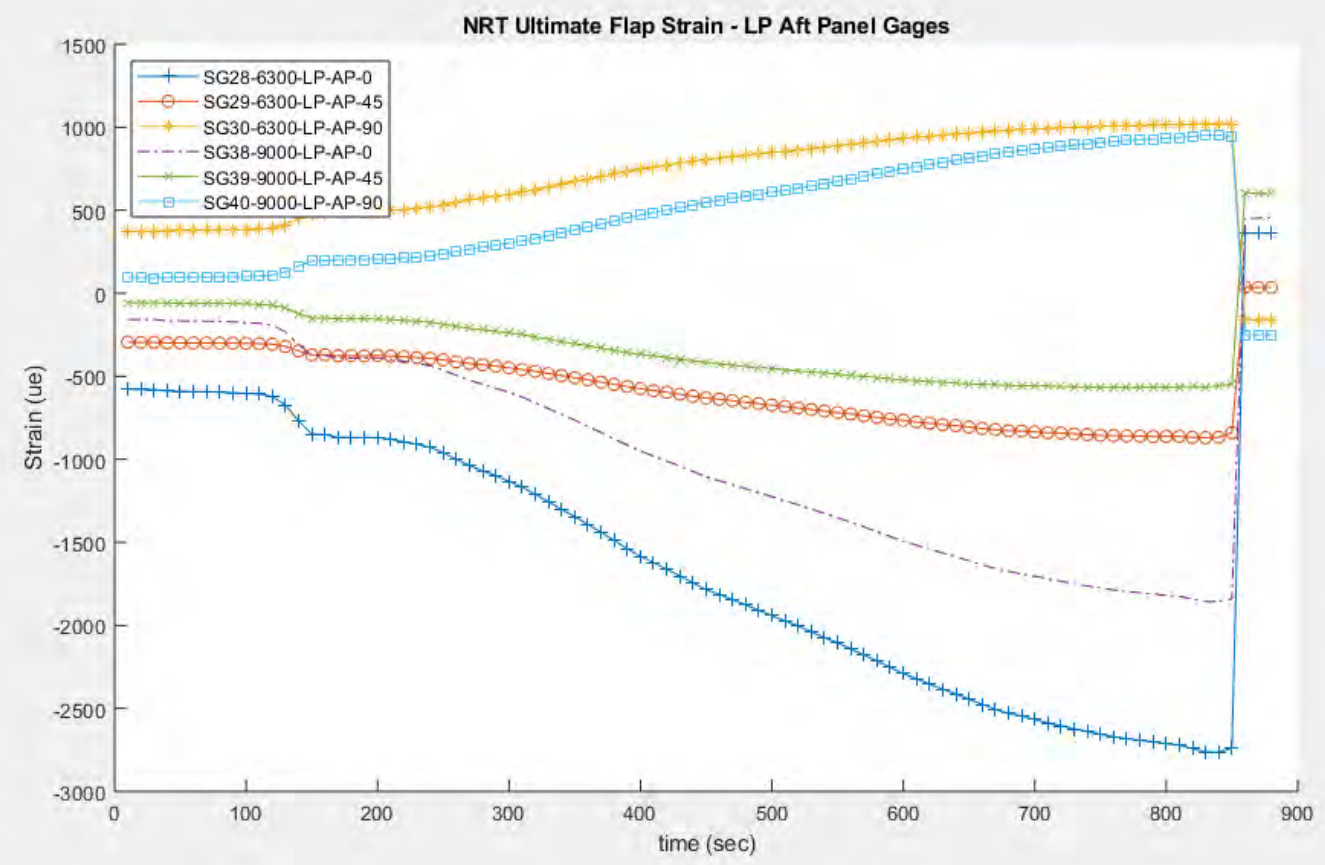

Figure $\mathrm{H}-7$

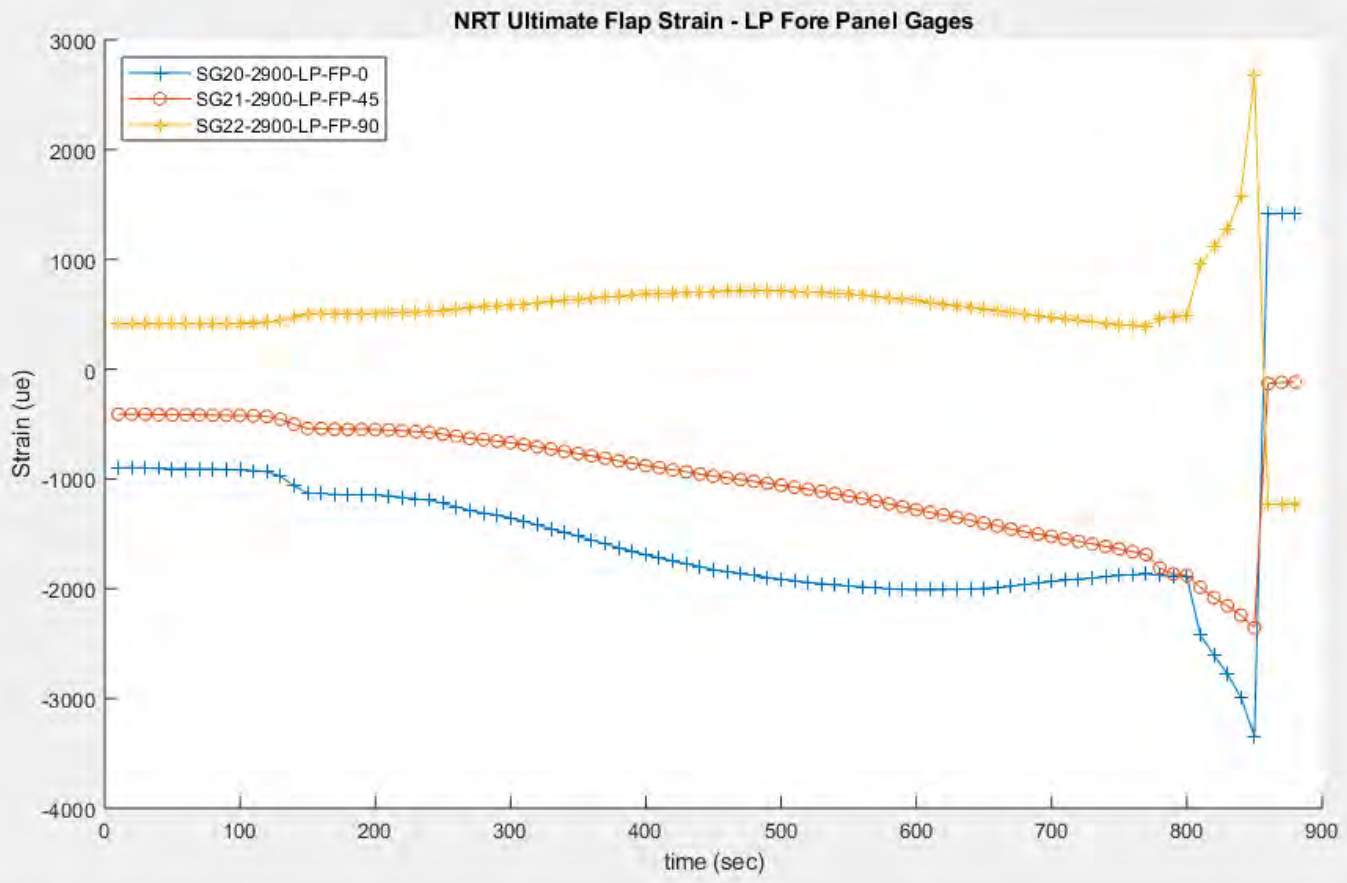

\section{Figure $\mathrm{H}-8$}




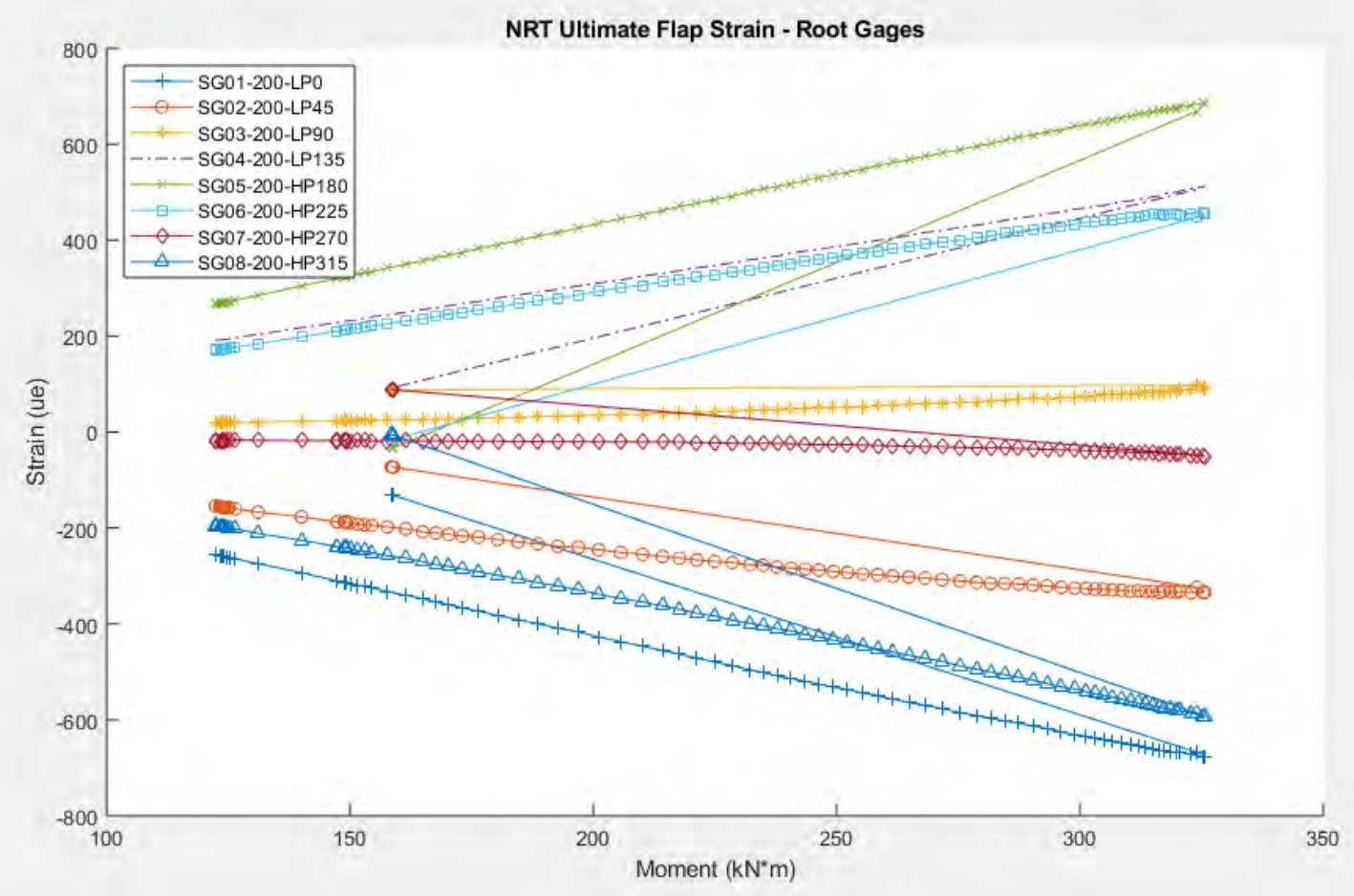

\section{Figure $\mathrm{H}-9$}

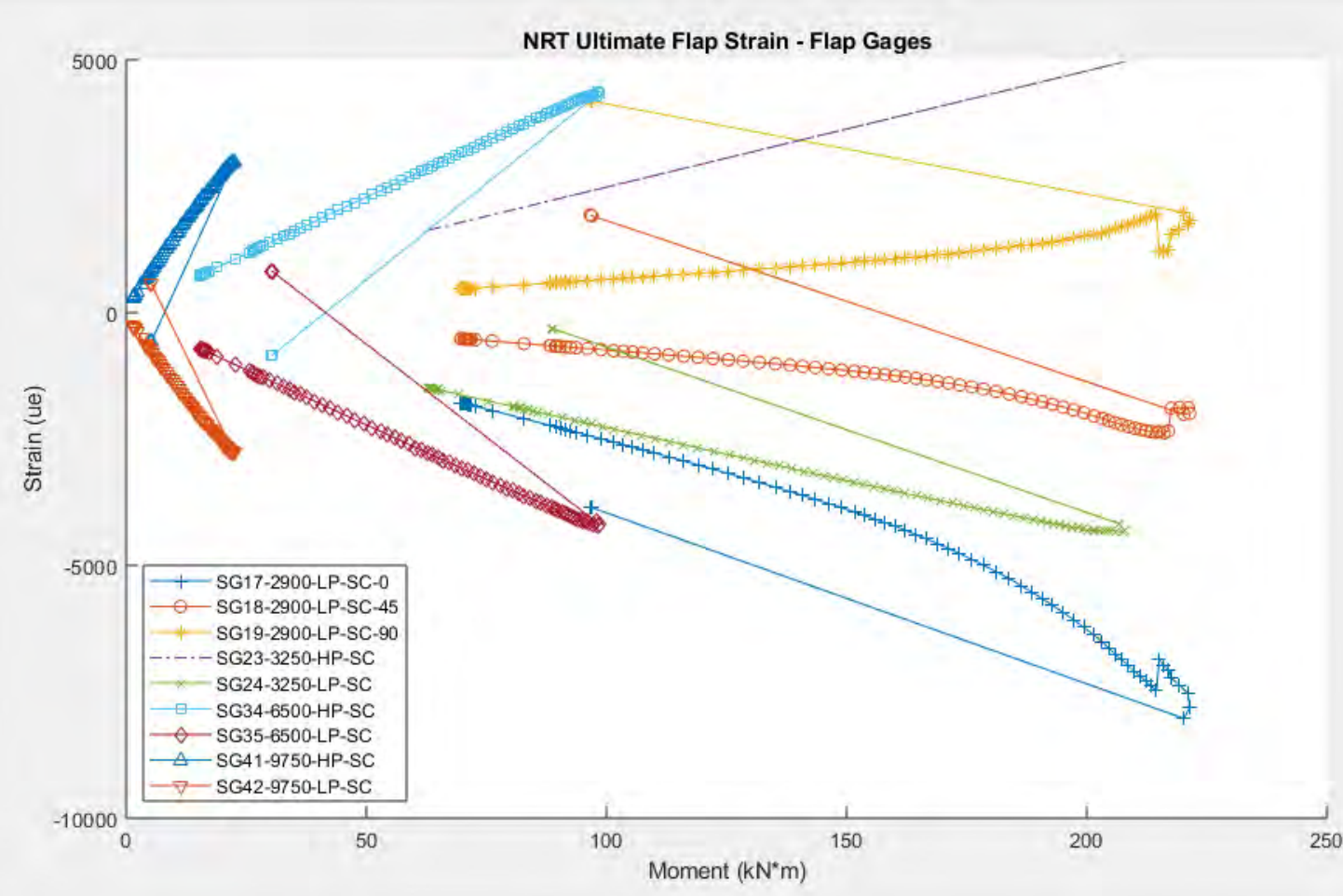

Figure $\mathrm{H}-10$ 


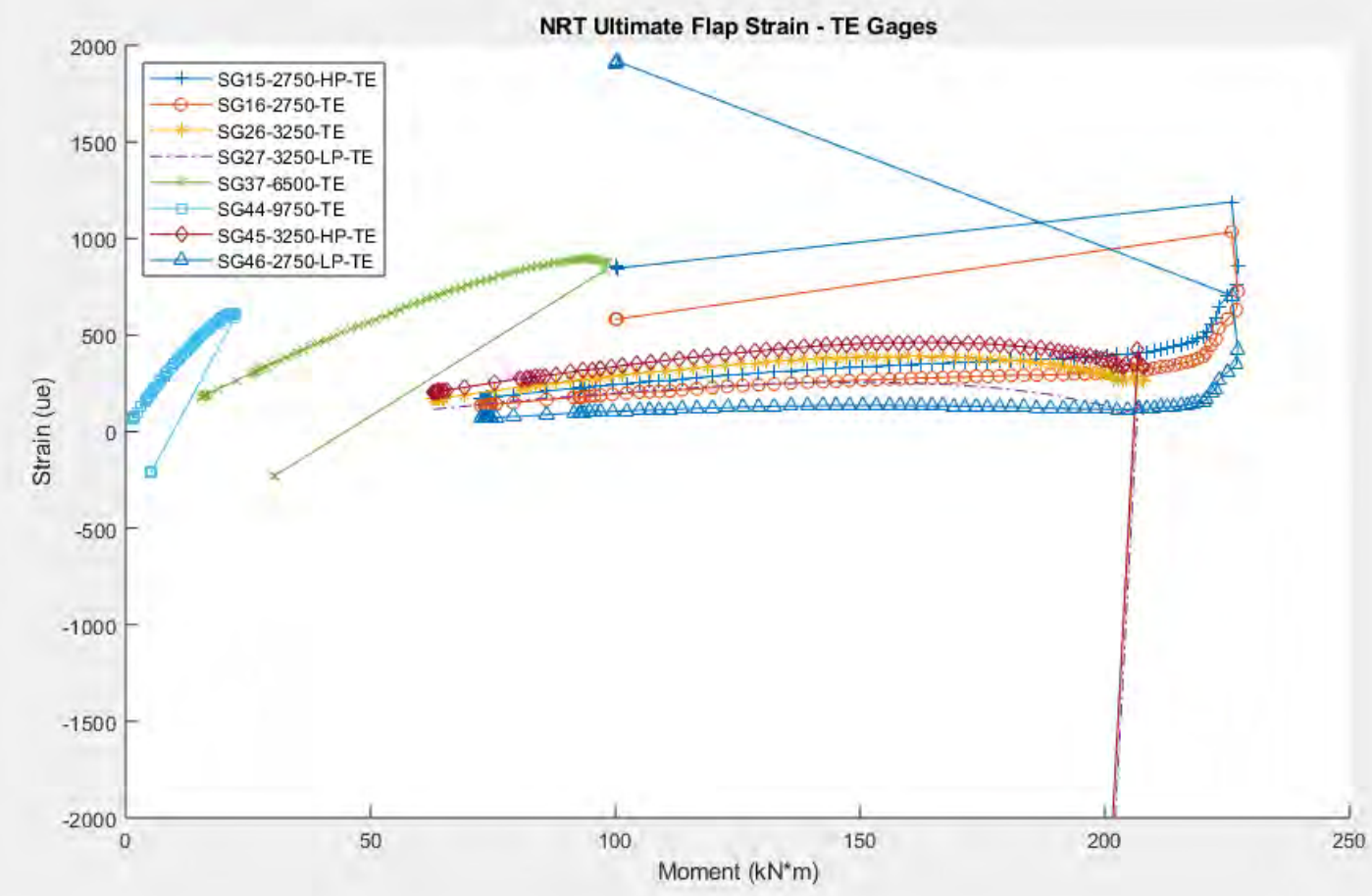

\section{Figure $\mathrm{H}-11$}

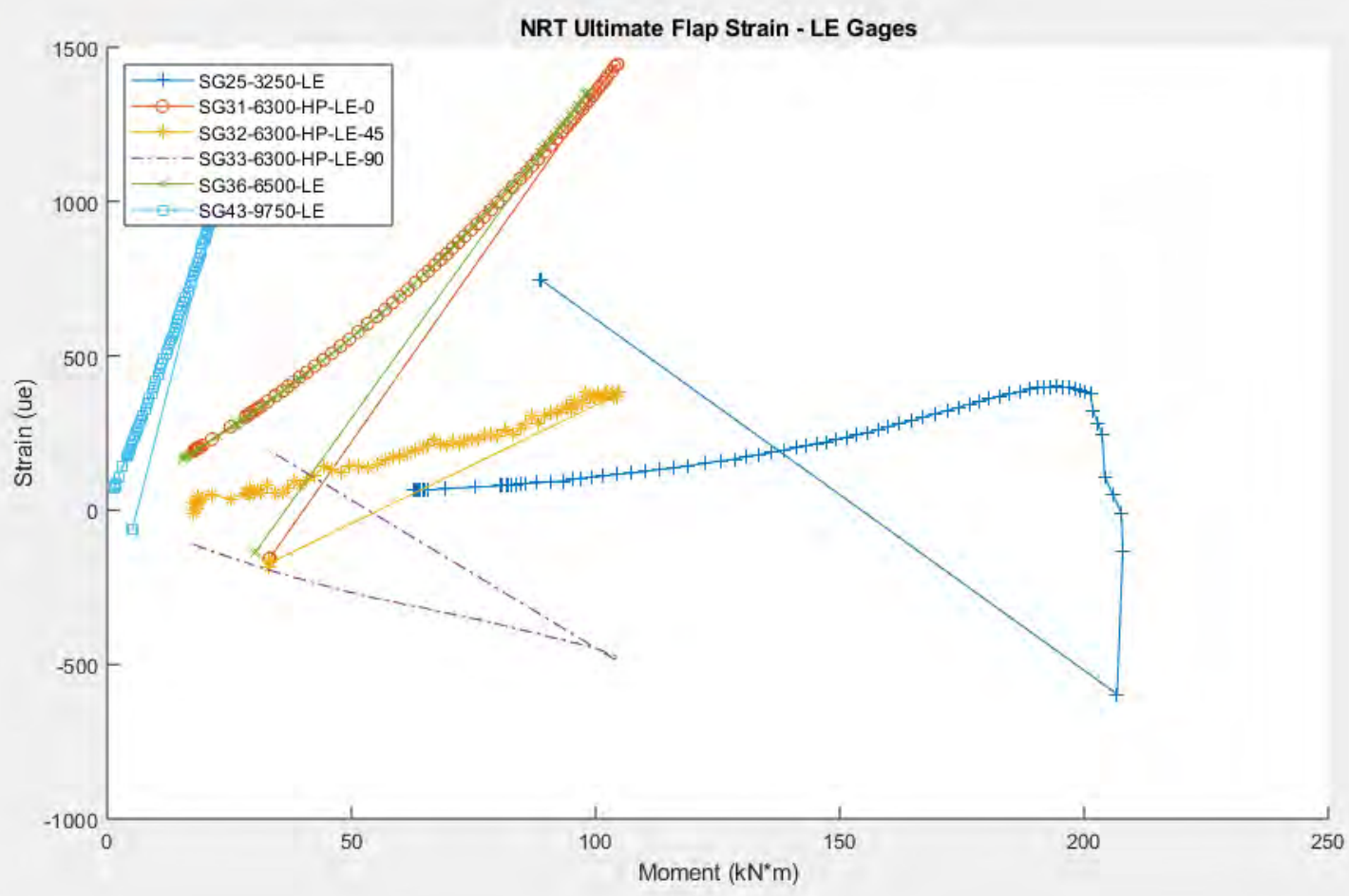

Figure $\mathrm{H}-12$ 


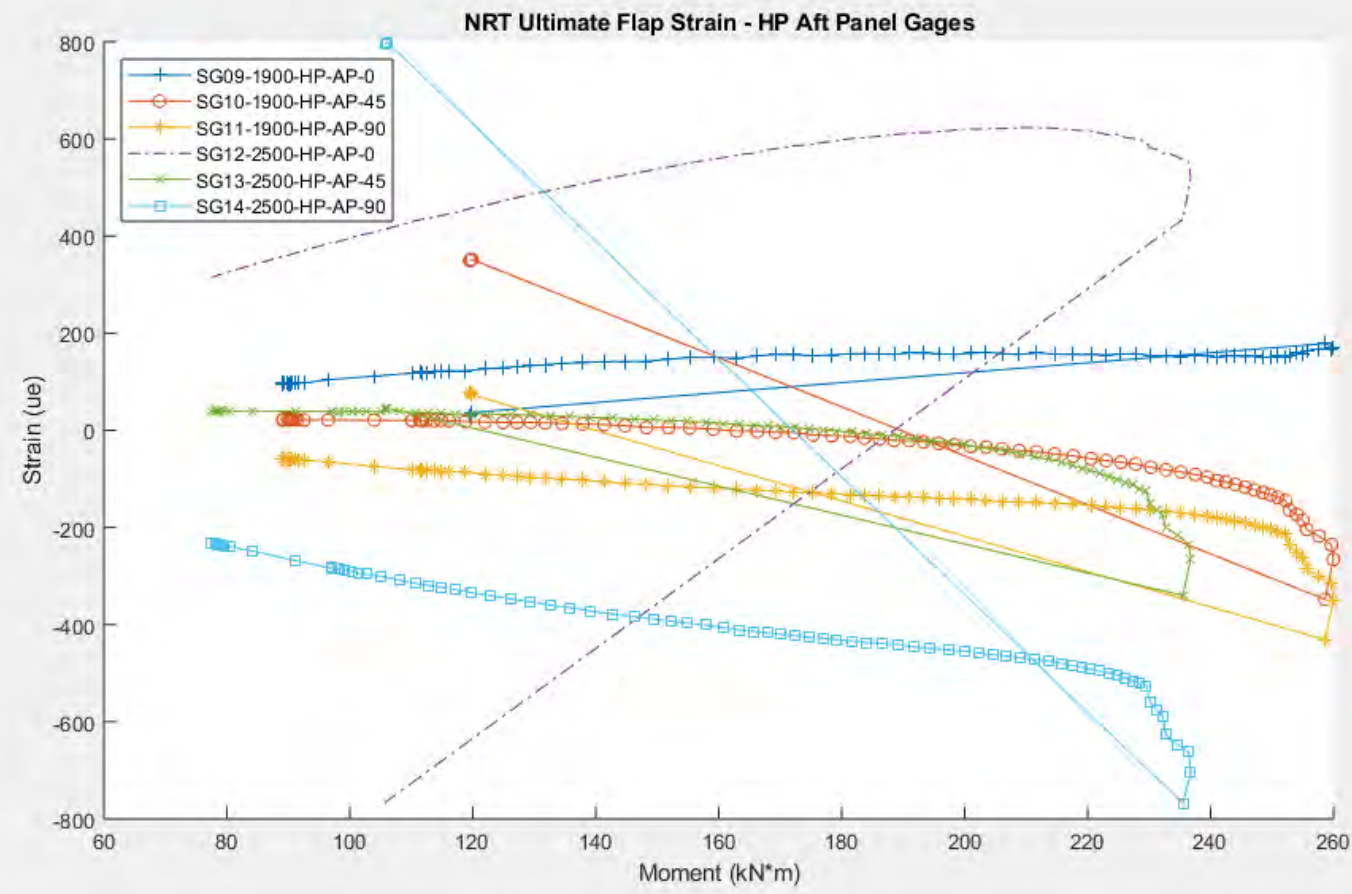

\section{Figure $\mathrm{H}-13$}

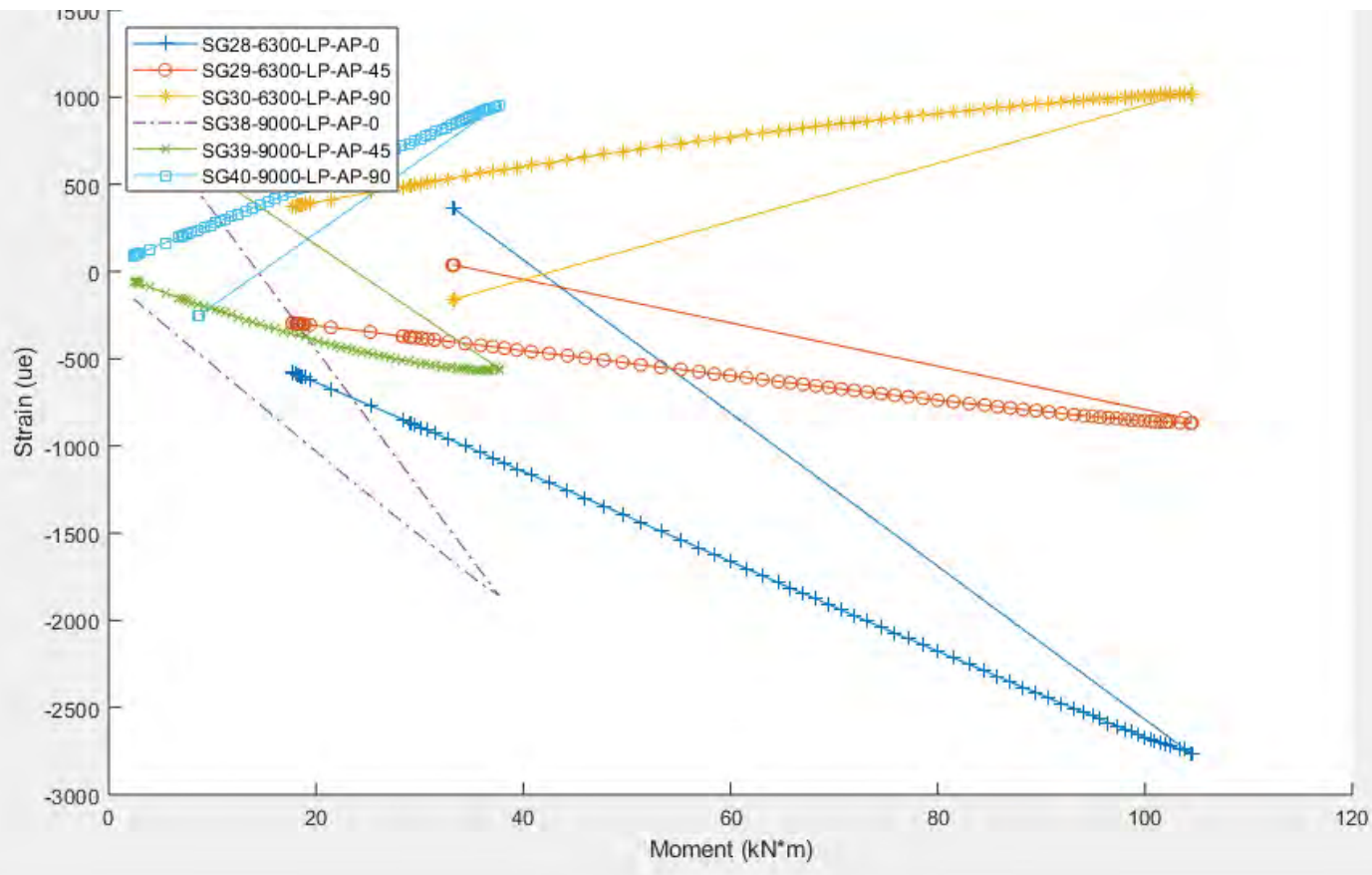

Figure $\mathrm{H}-14$ 


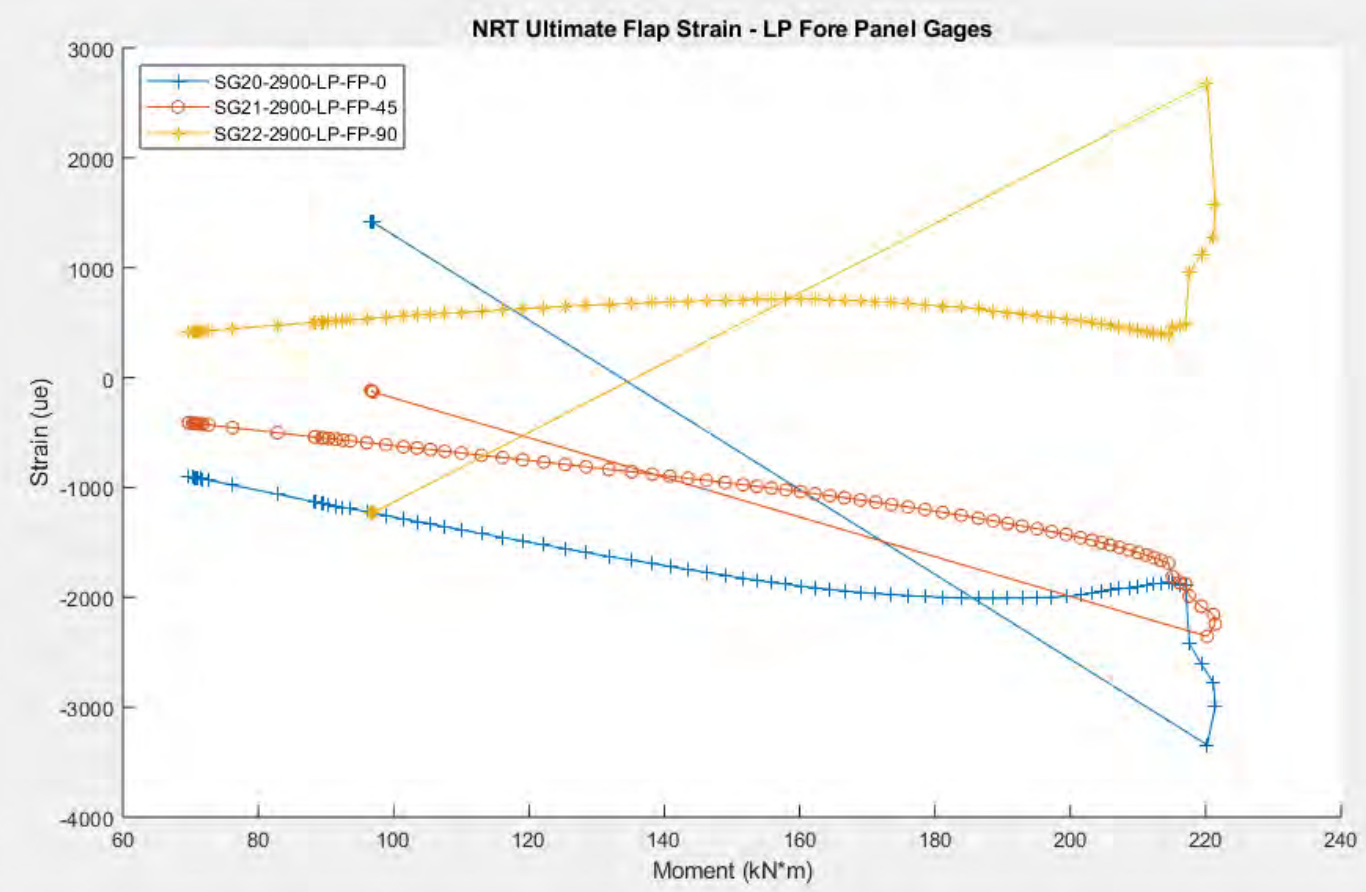

Figure $\mathrm{H}-15$

SNL_2017 - Sandia NRT Blade-0 Laboratory Structural Test Report

This report is available at no cost from the National Renewable Energy Laboratory at www.nrel.gov/publications. 


\section{APPENDIX I - Test Photographs}

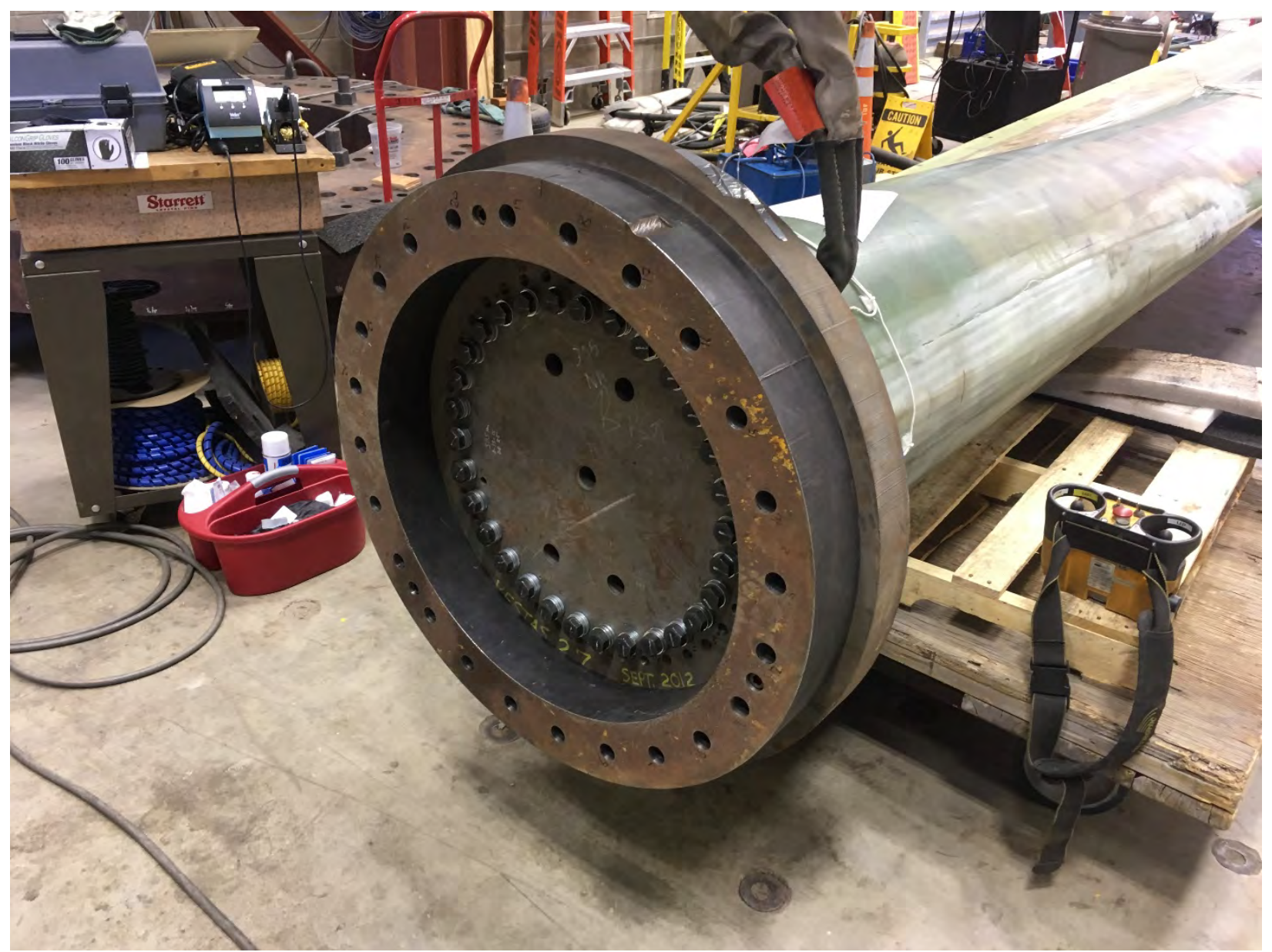

Figure I-1. Adapter Plate Mounting Configuration for Static Proof Load Tests 


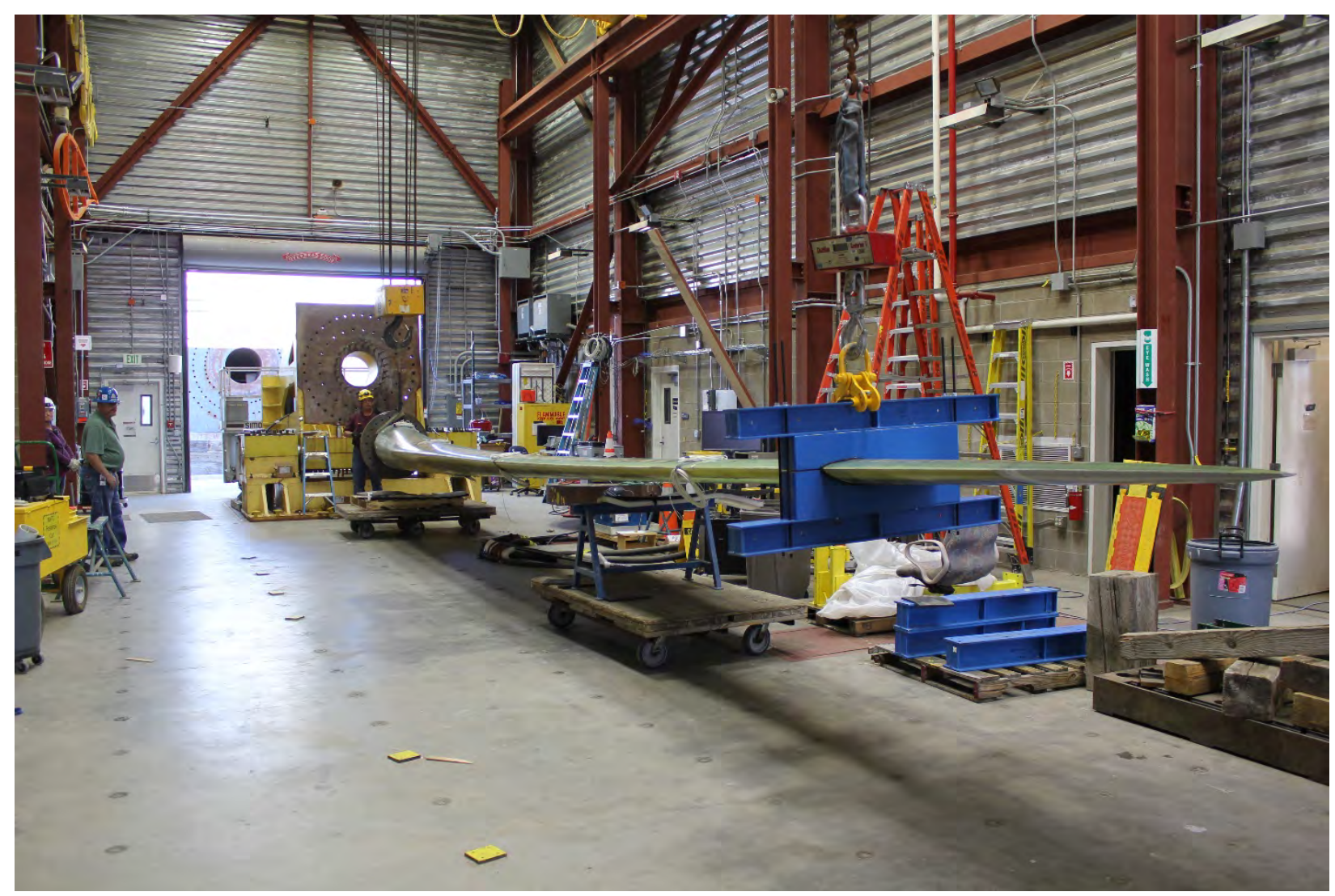

Figure I-2. Preparing to Mount Blade for Maximum Flap Load Case 


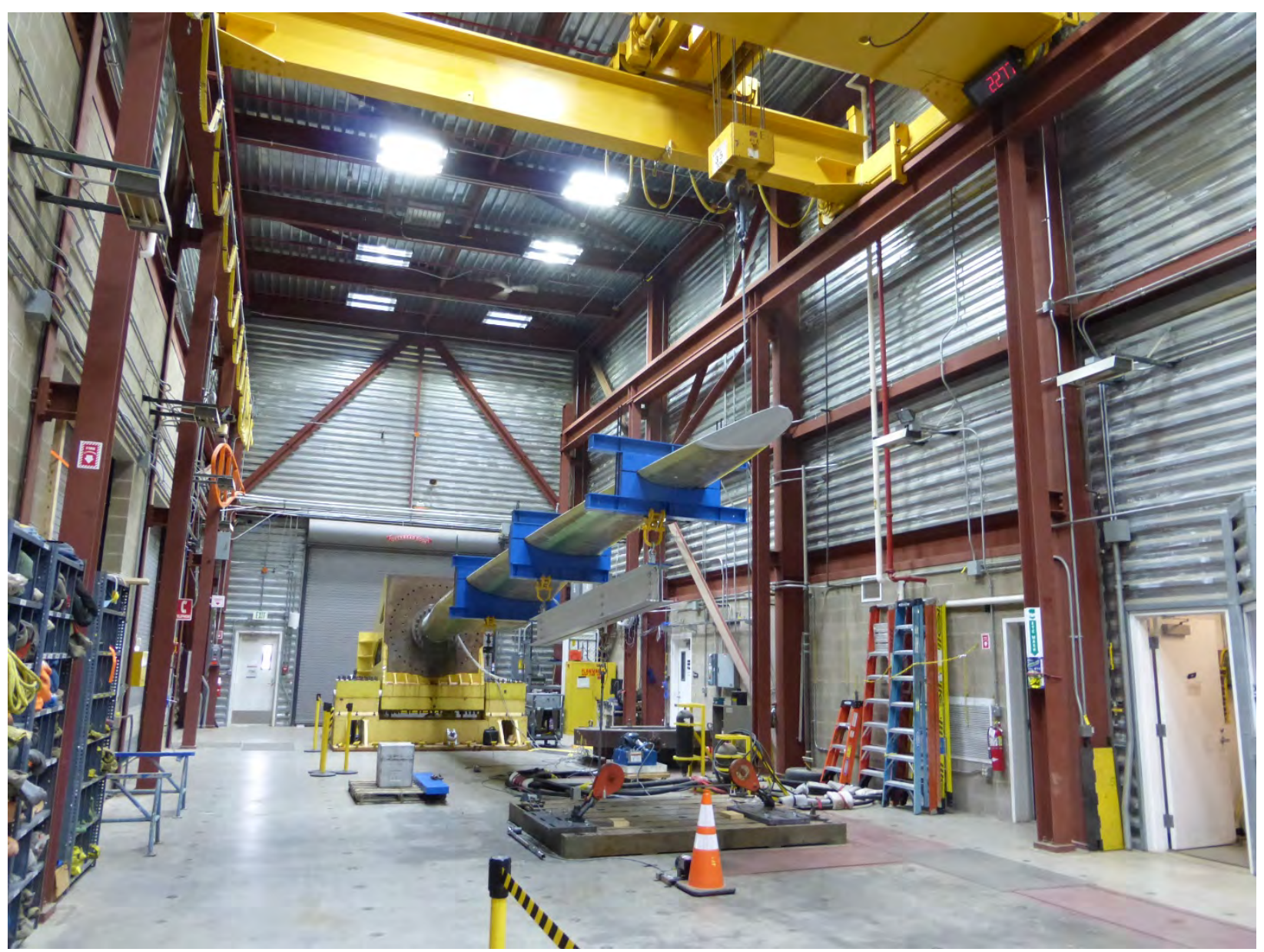

Figure I-3. Maximum Flap Test Setup 


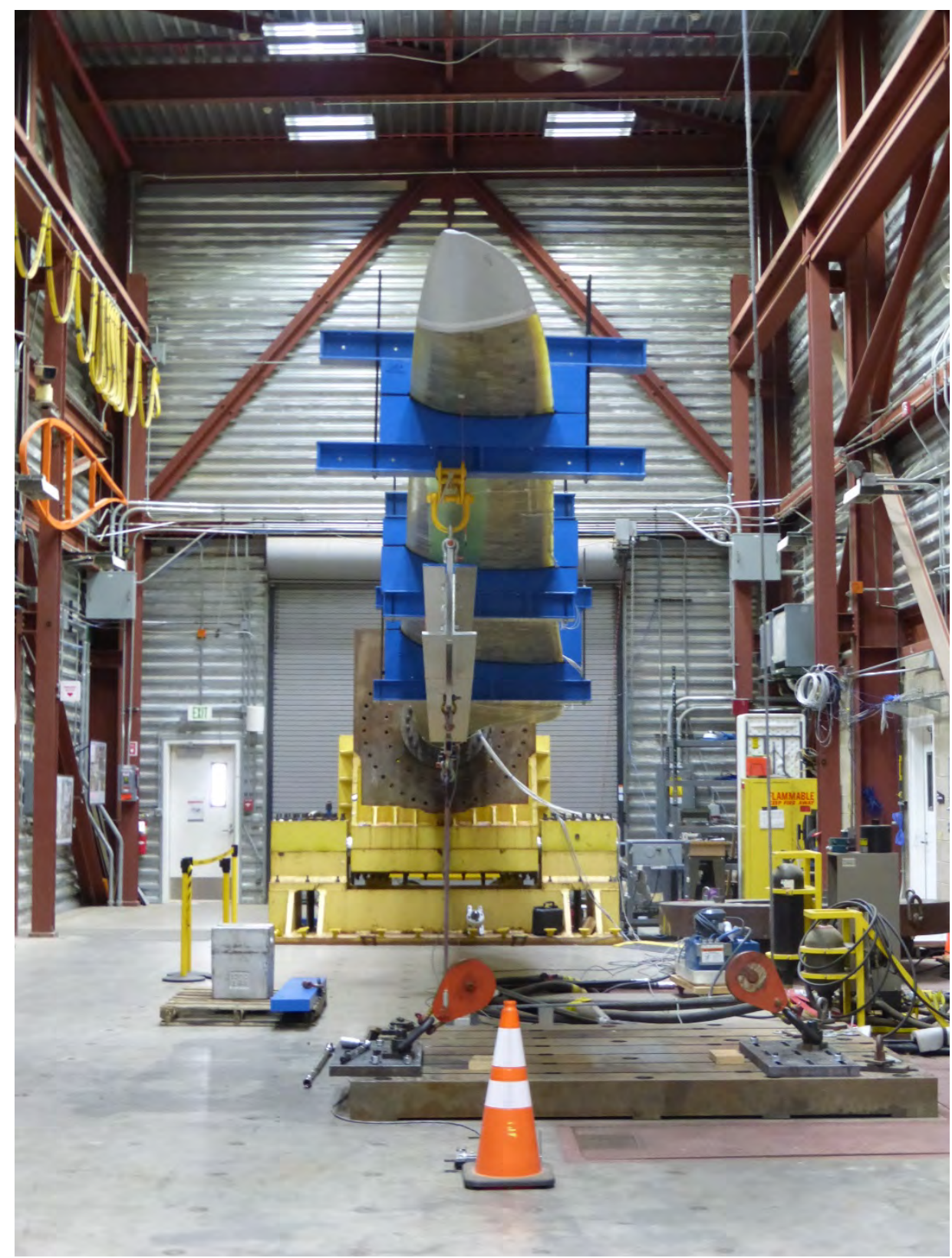

Figure I-4. Max Flap setup showing rigging line from spreader bar to overhead crane 


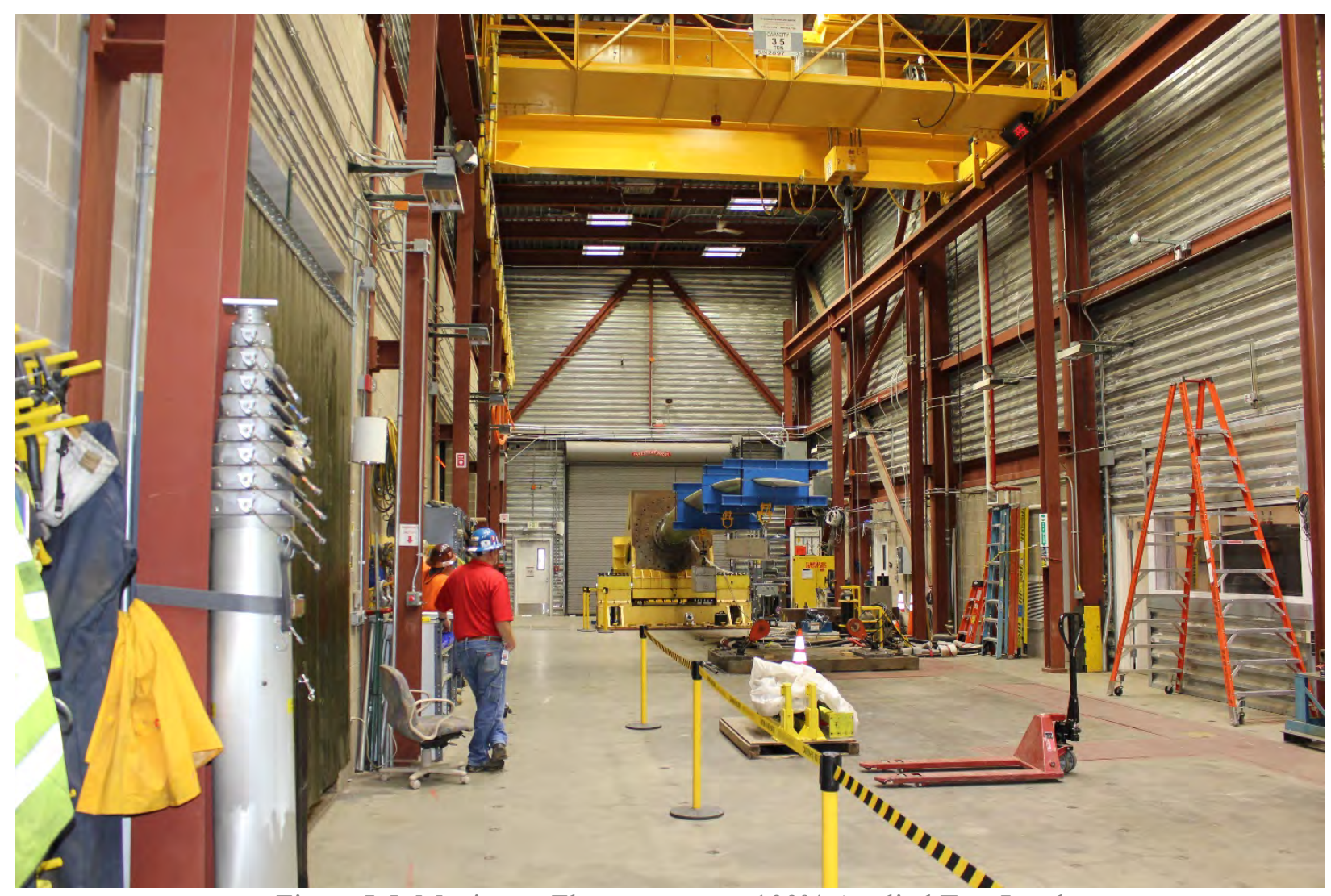

Figure I-5. Maximum Flap near target 100\% Applied Test Load 


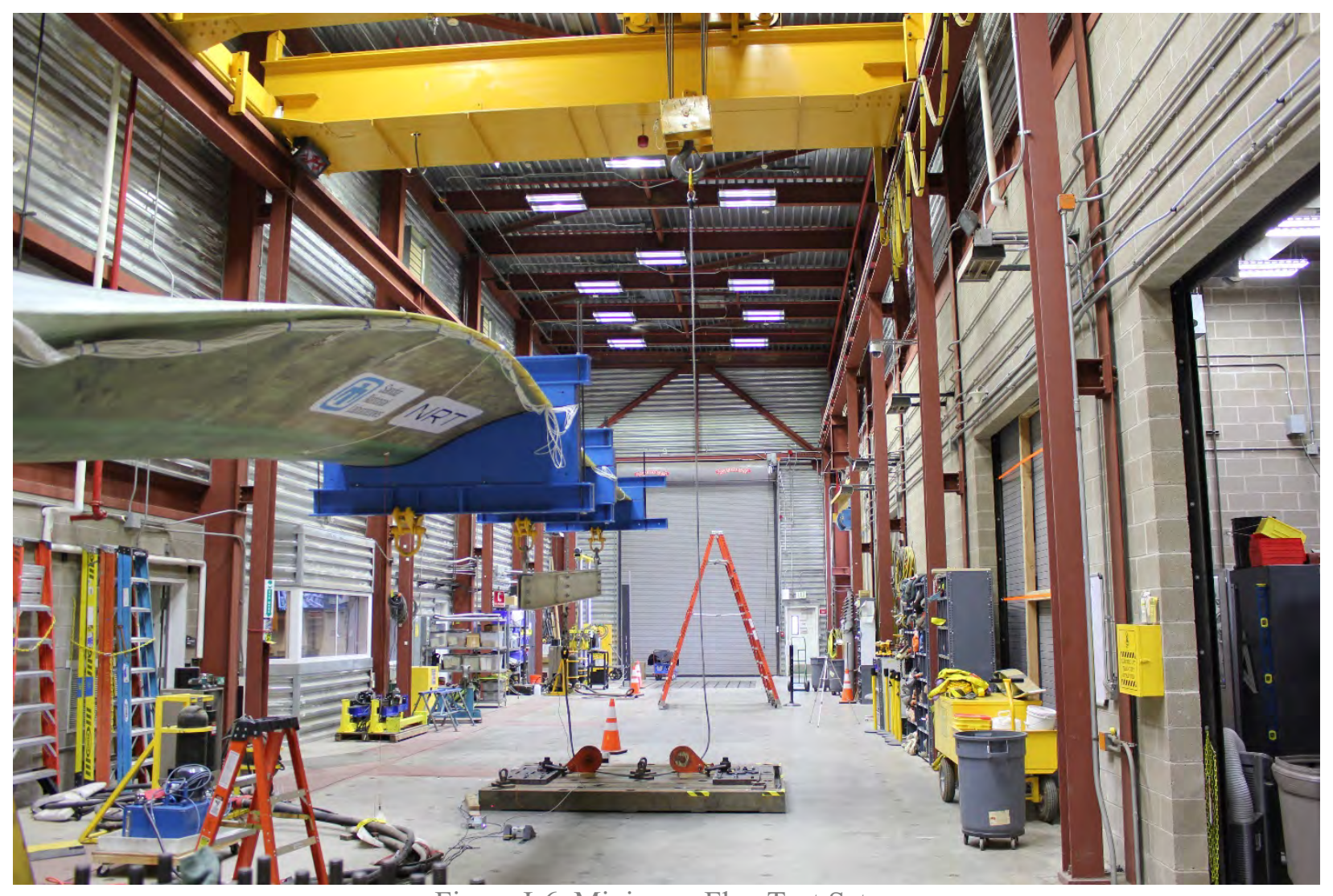

Figure I-6. Minimum Flap Test Setup 


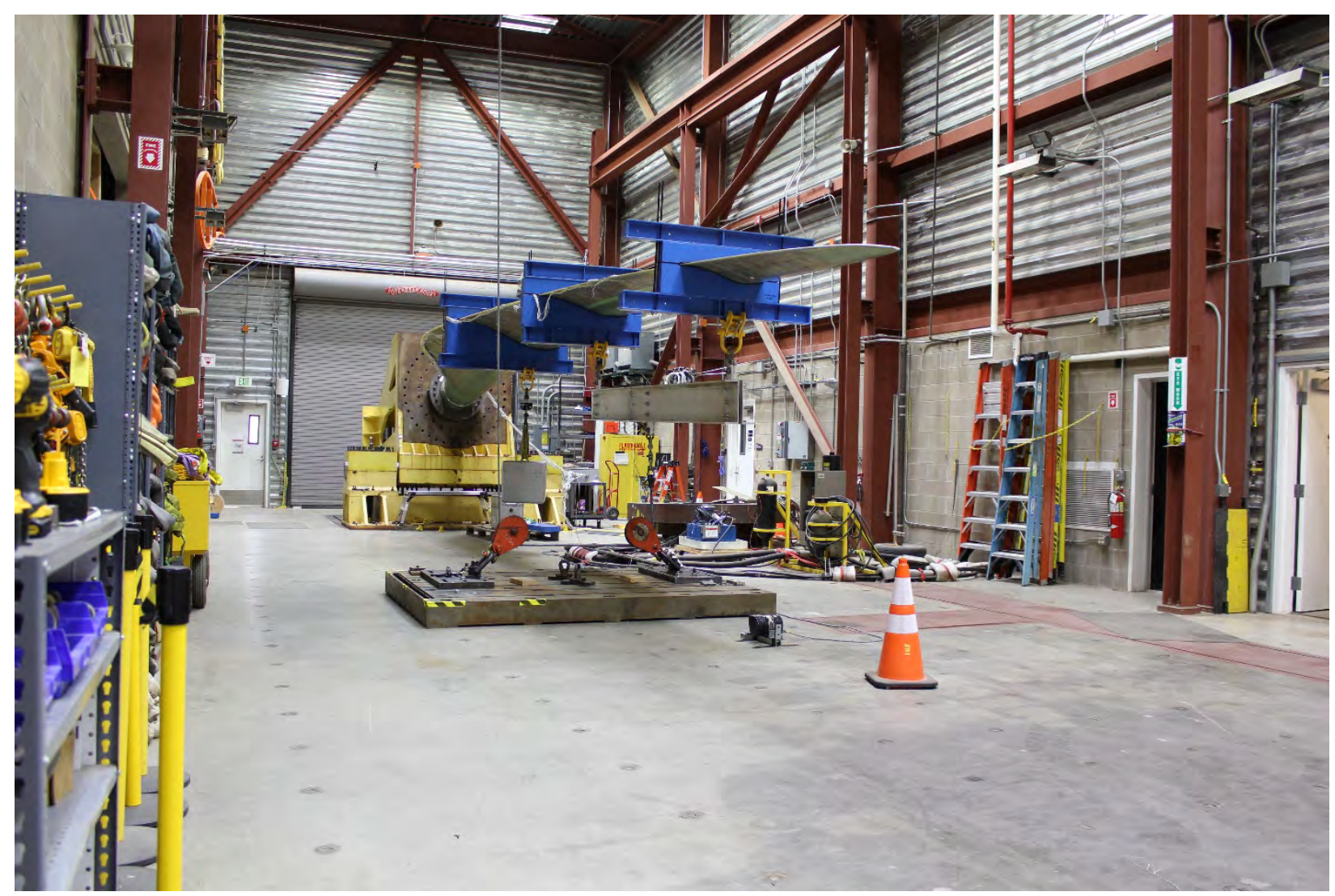

Figure I-7. Minimum Flap near Target Applied Test Moment 


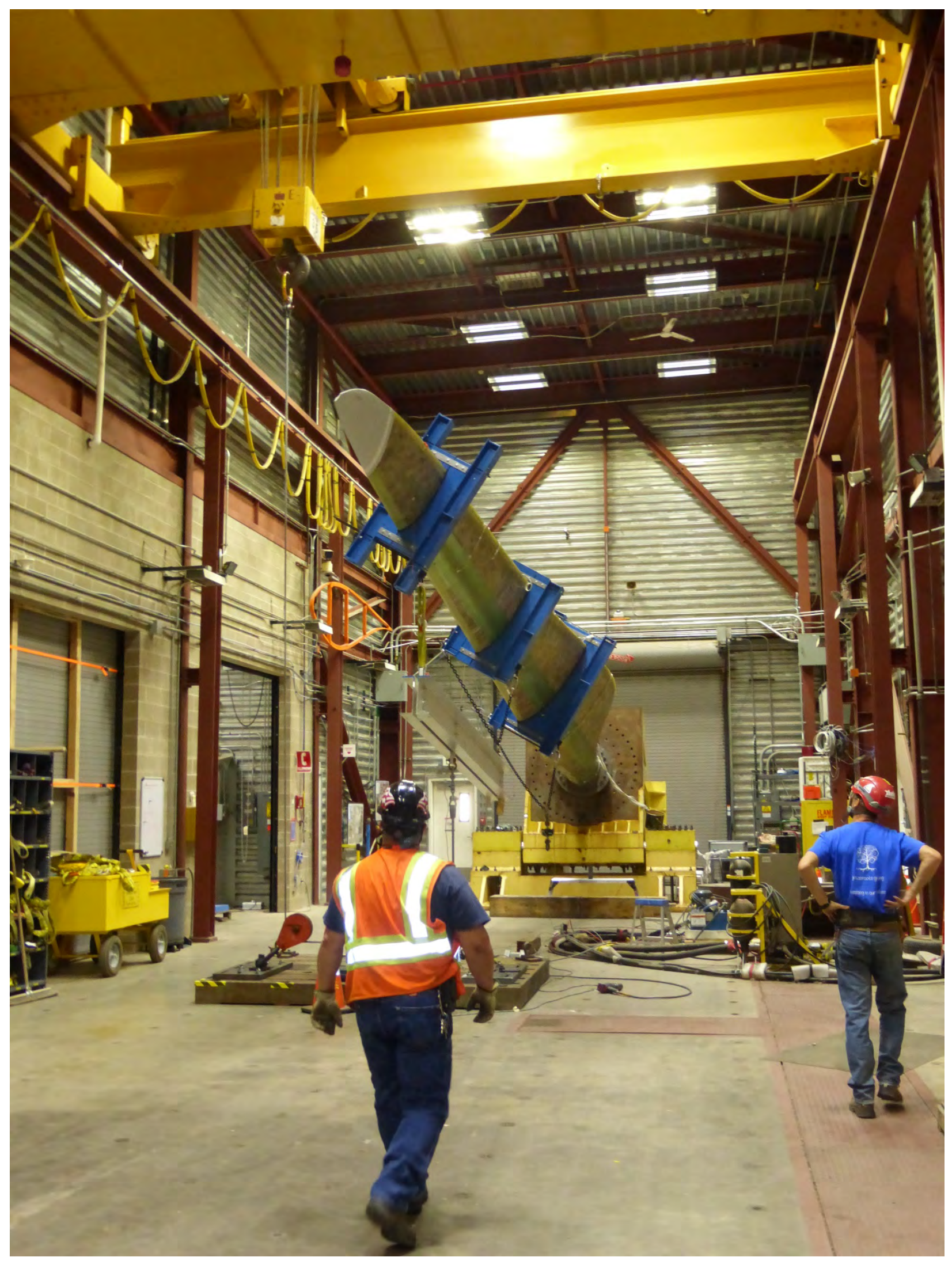

Figure I-8. Maximum Edge setup 


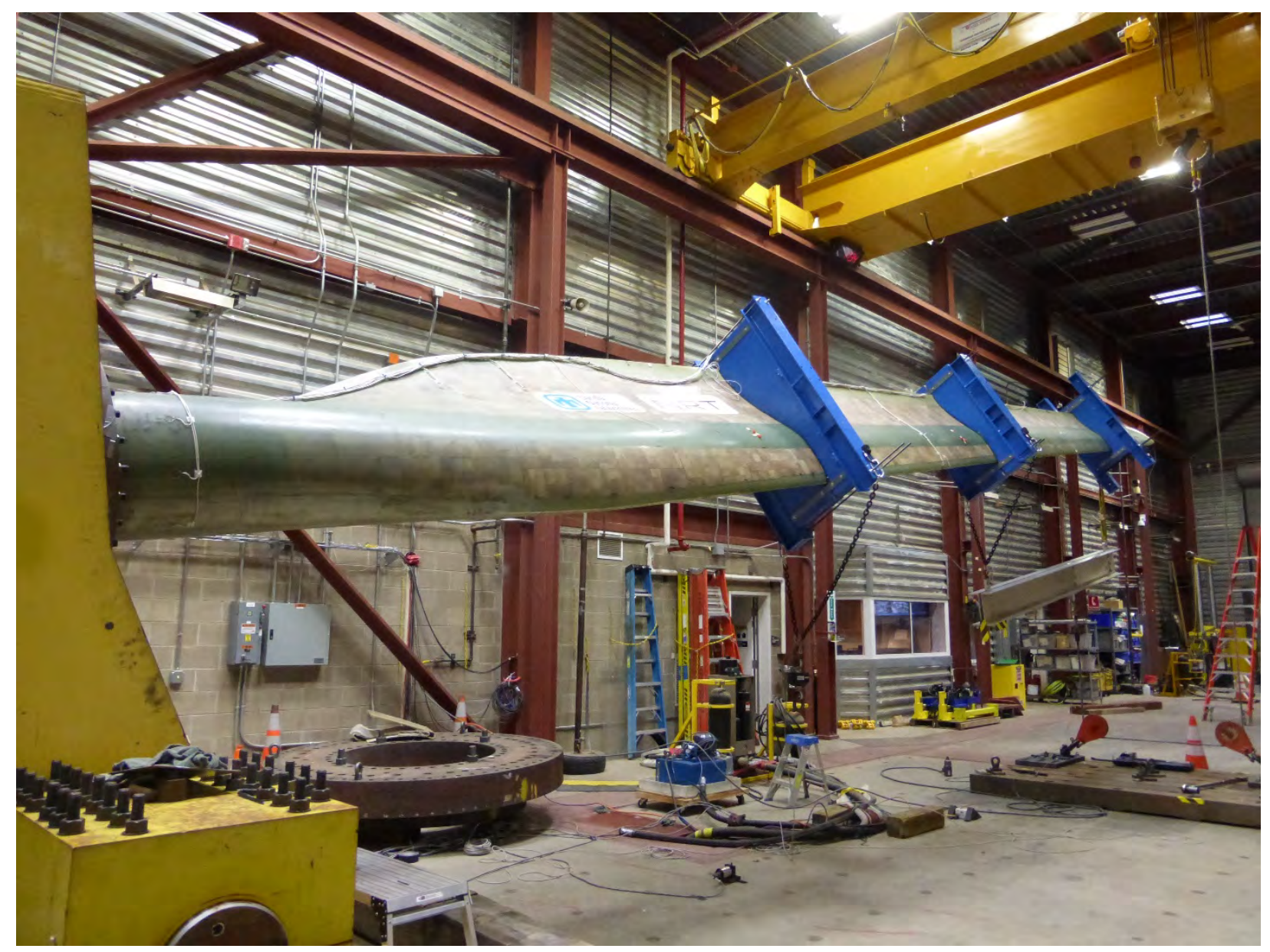

Figure I-9. Maximum Edge Setup 


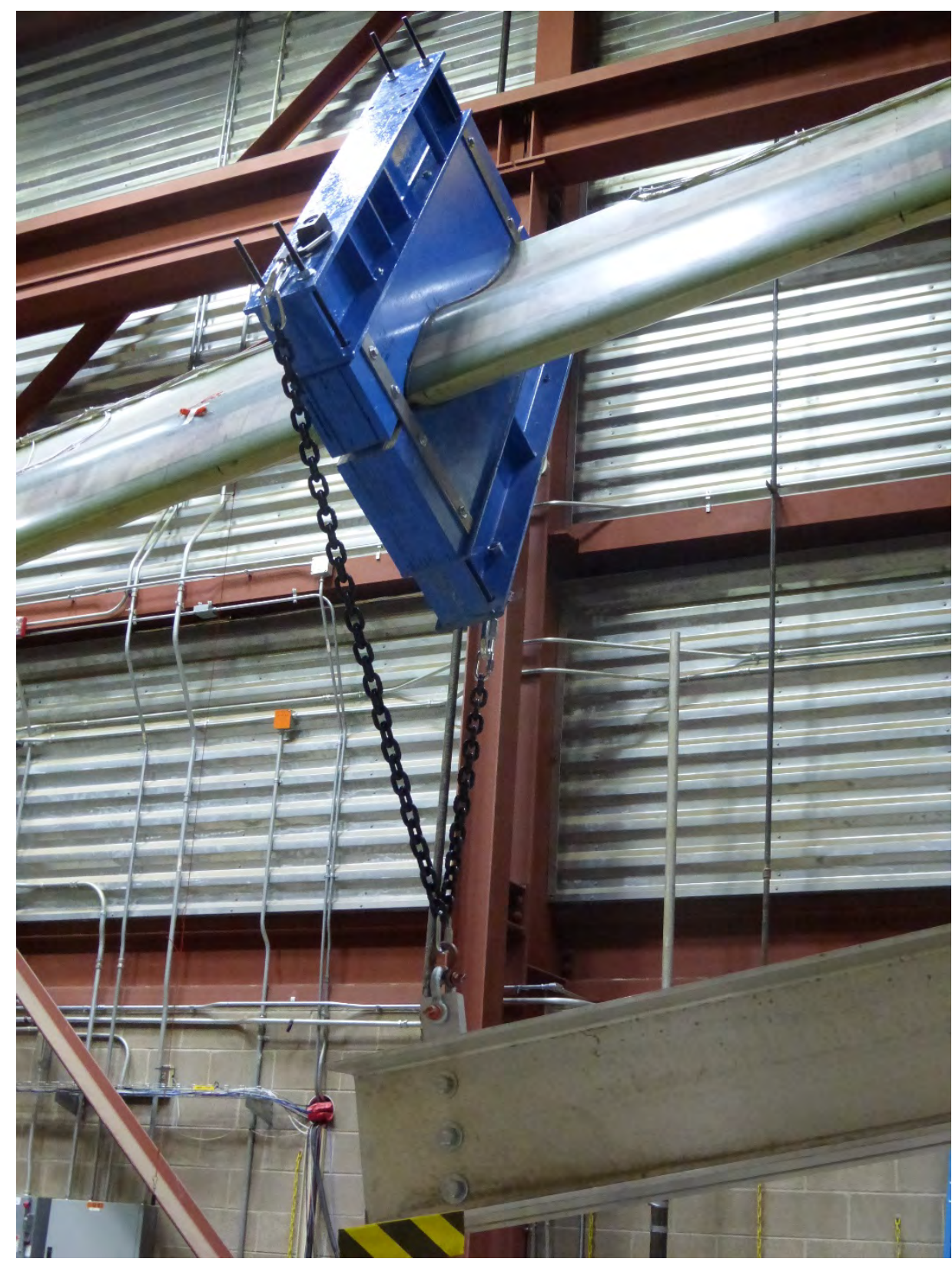

Figure I-10. Maximum Edge, 7.55 m Saddle and Connection to Spreader Bar 


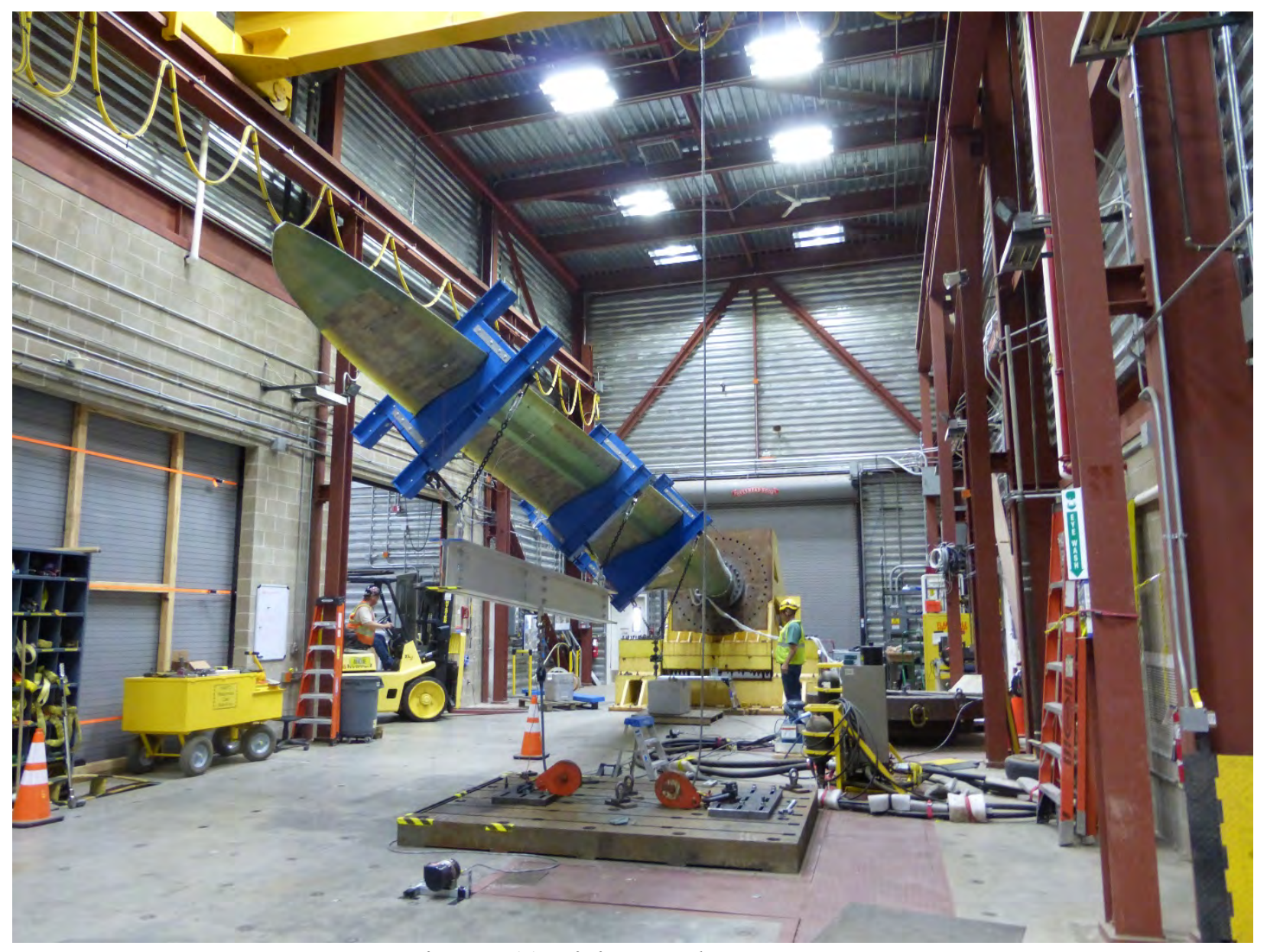

Figure I-11 Minimum Edge Test setup 


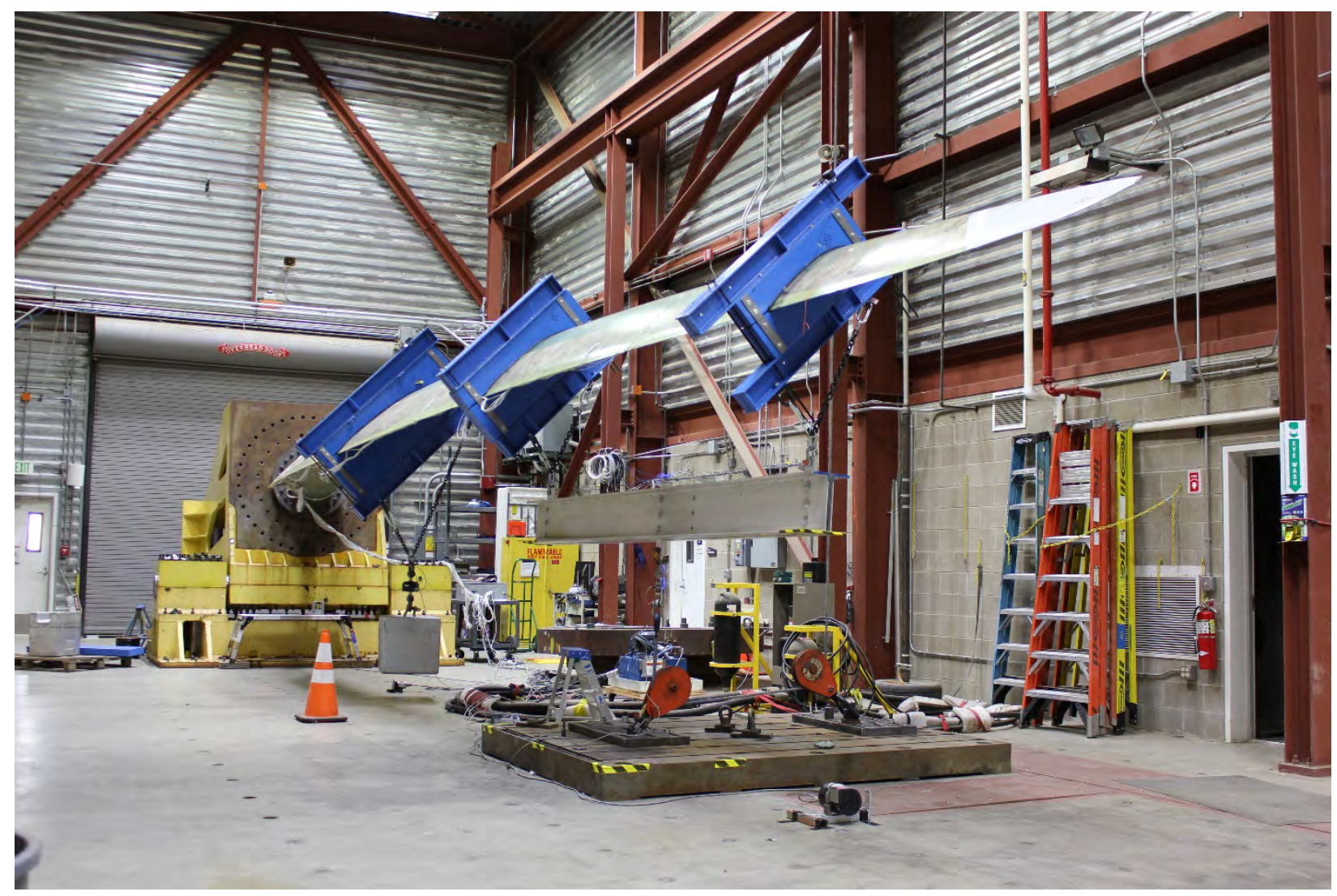

Figure I-12. Minimum Edge Near 100\% Target Load 


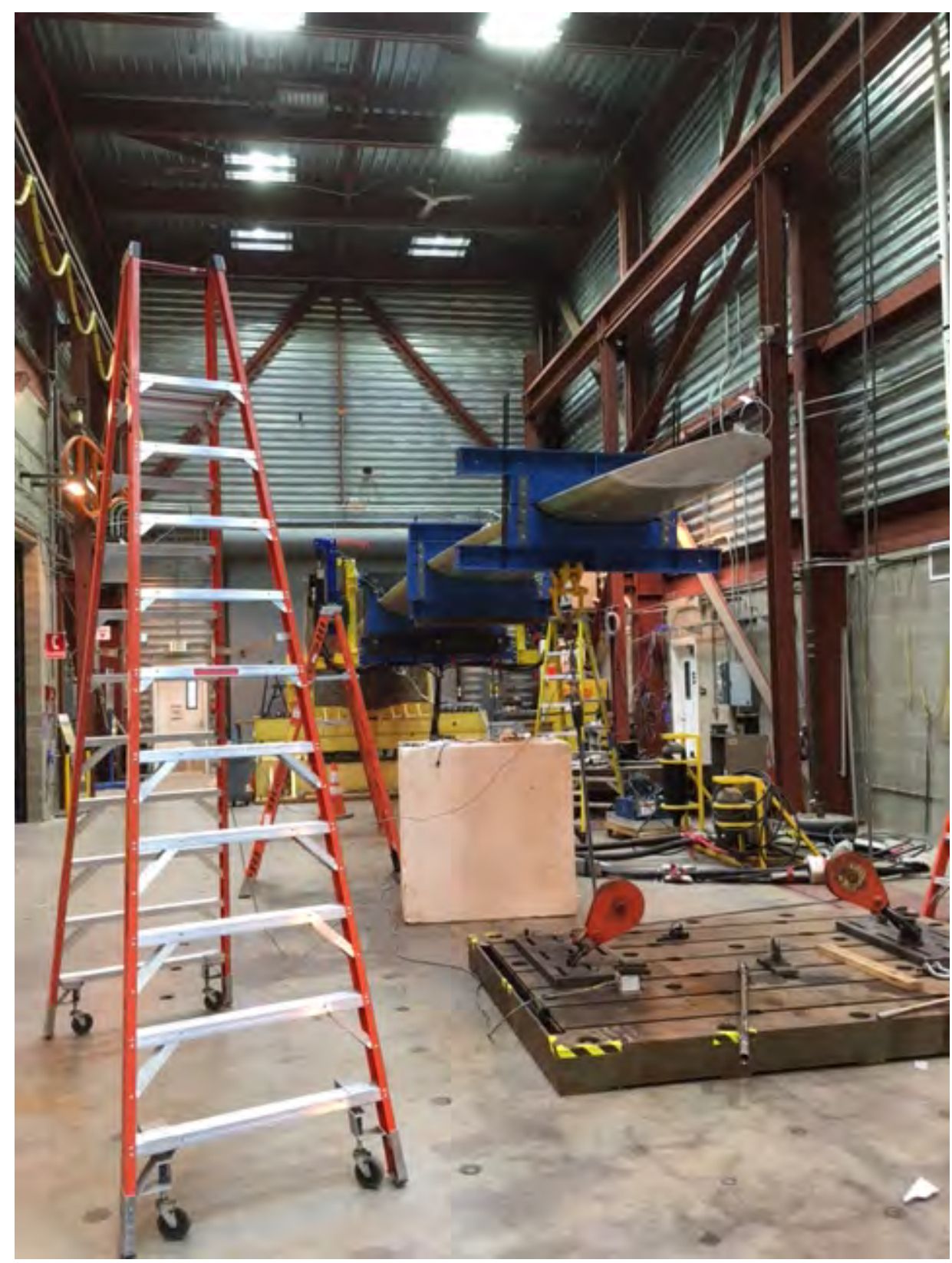

Figure I-13. Flapwise Calibration Pull for Fatigue Test Setup 


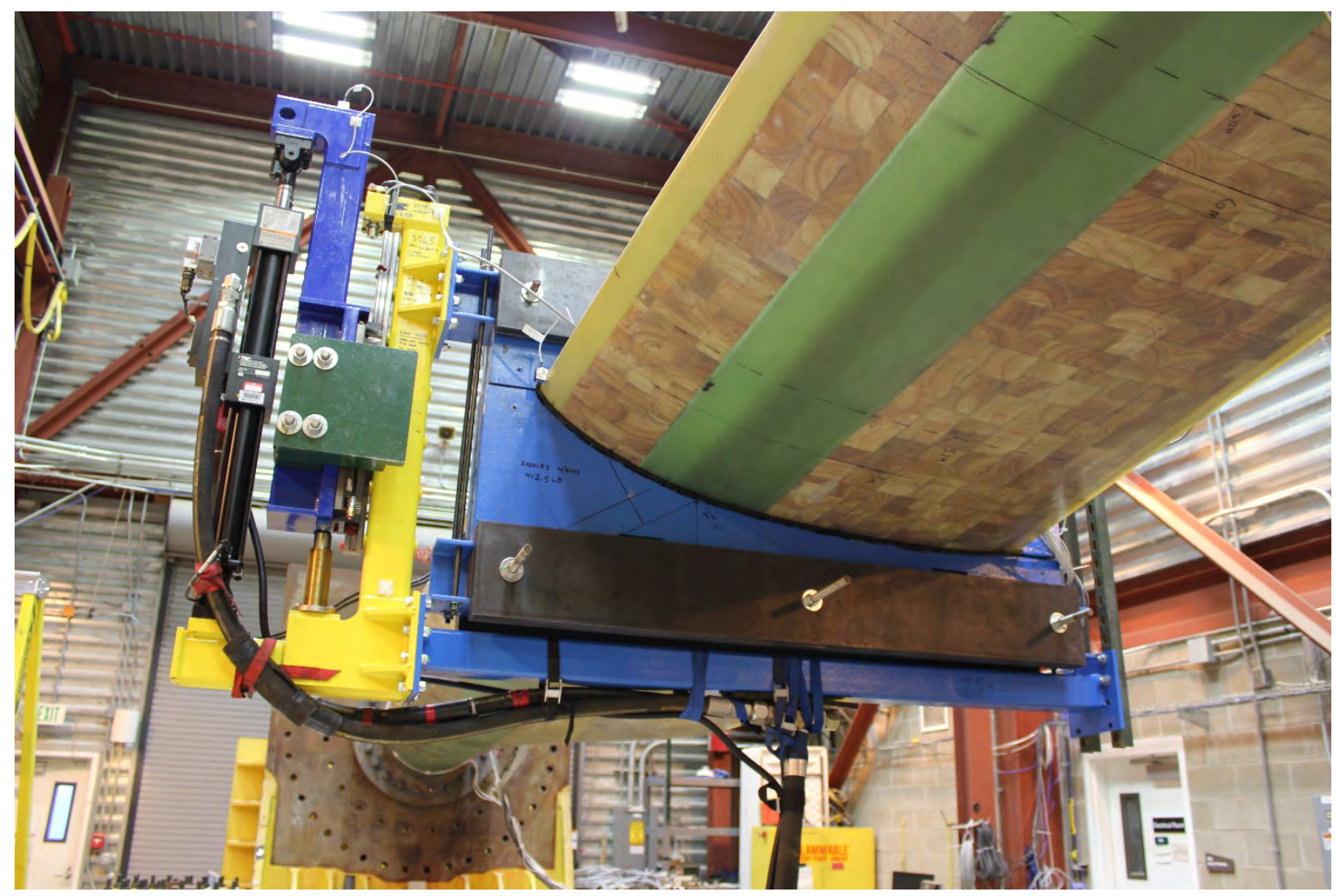

Figure I-14. South UREX for Fatigue Testing 


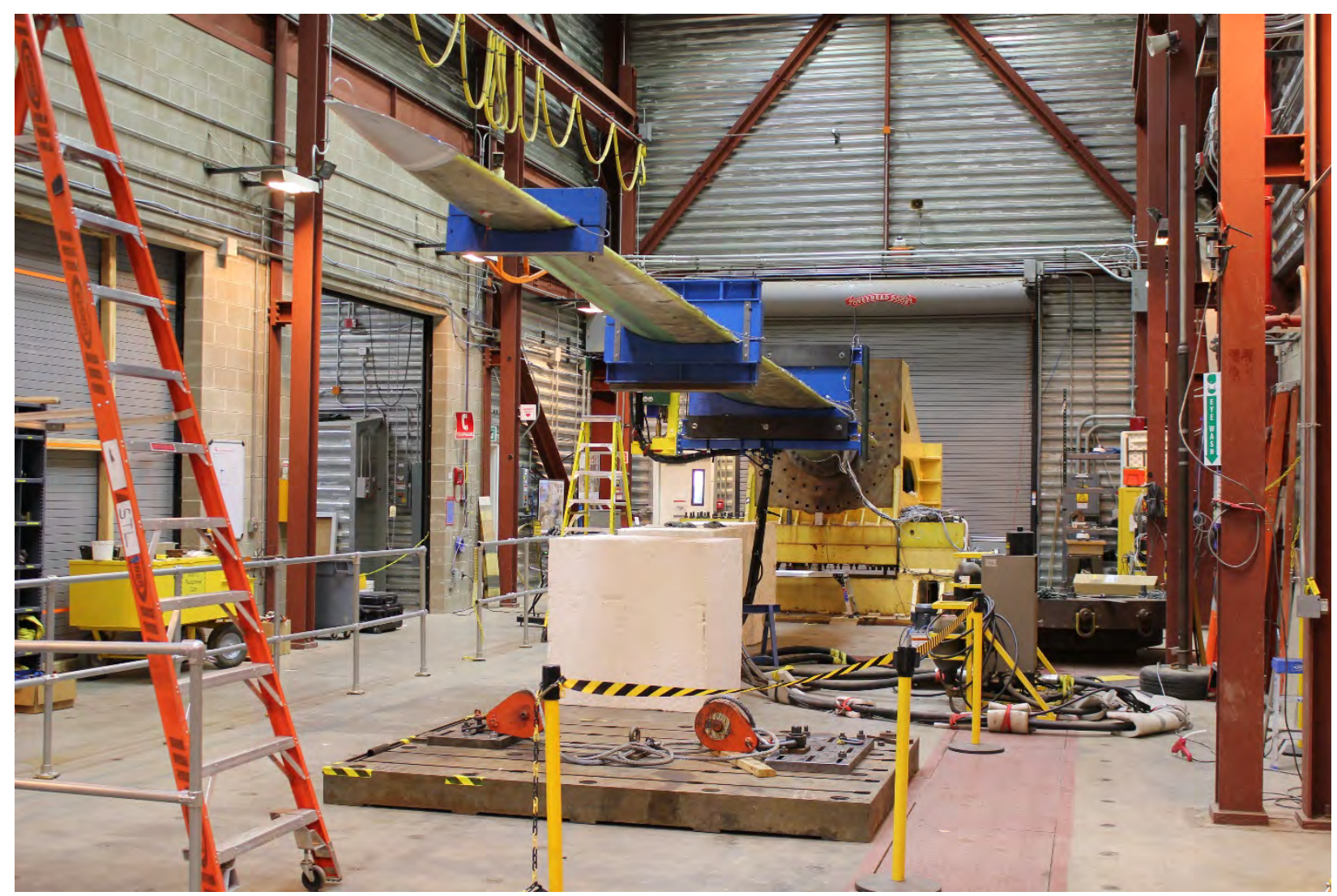

Figure I-15. Fatigue Test Setup. Single UREX on South, or Leading Edge side 


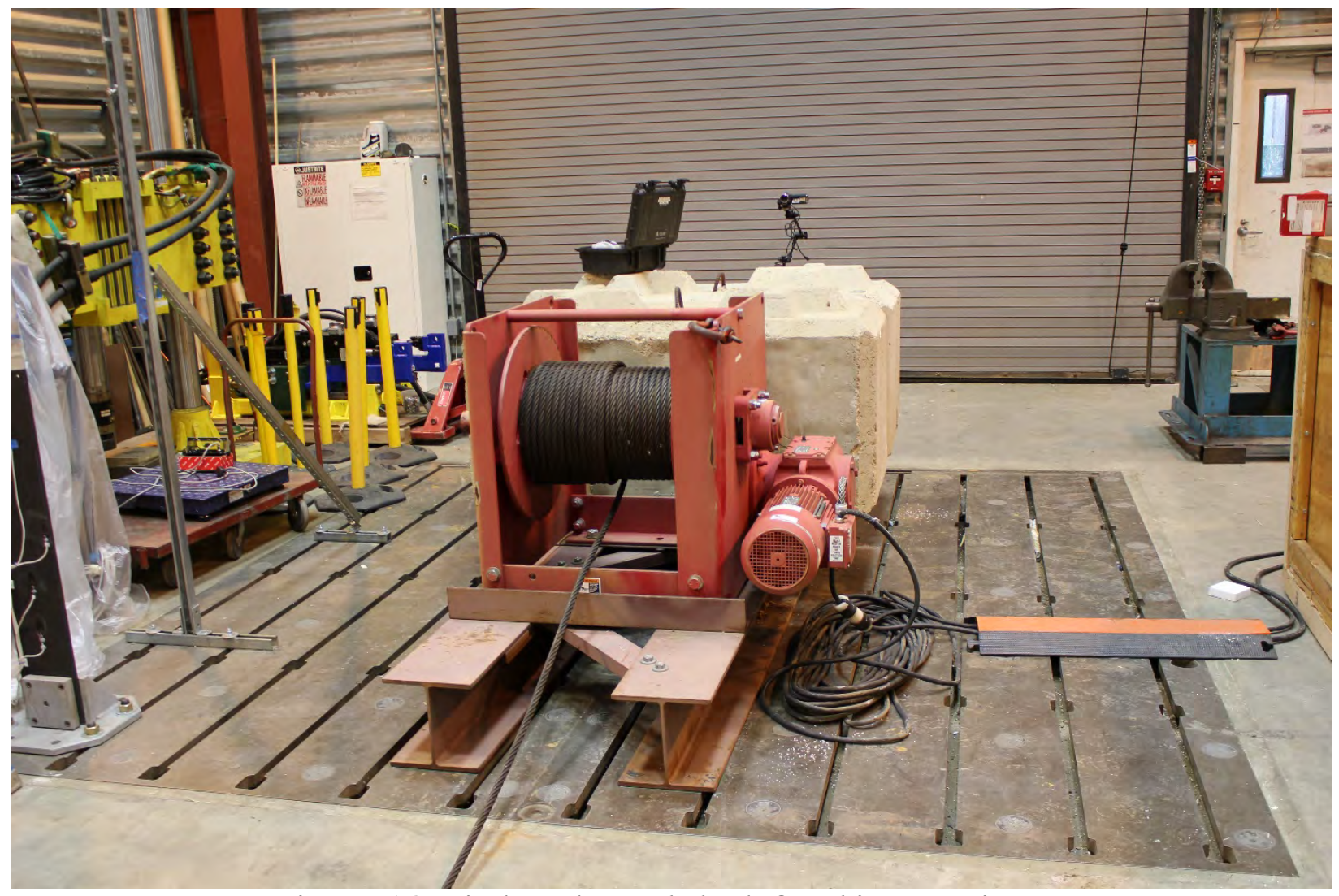

Figure I-16. Winch used to apply loads for Ultimate Static Test

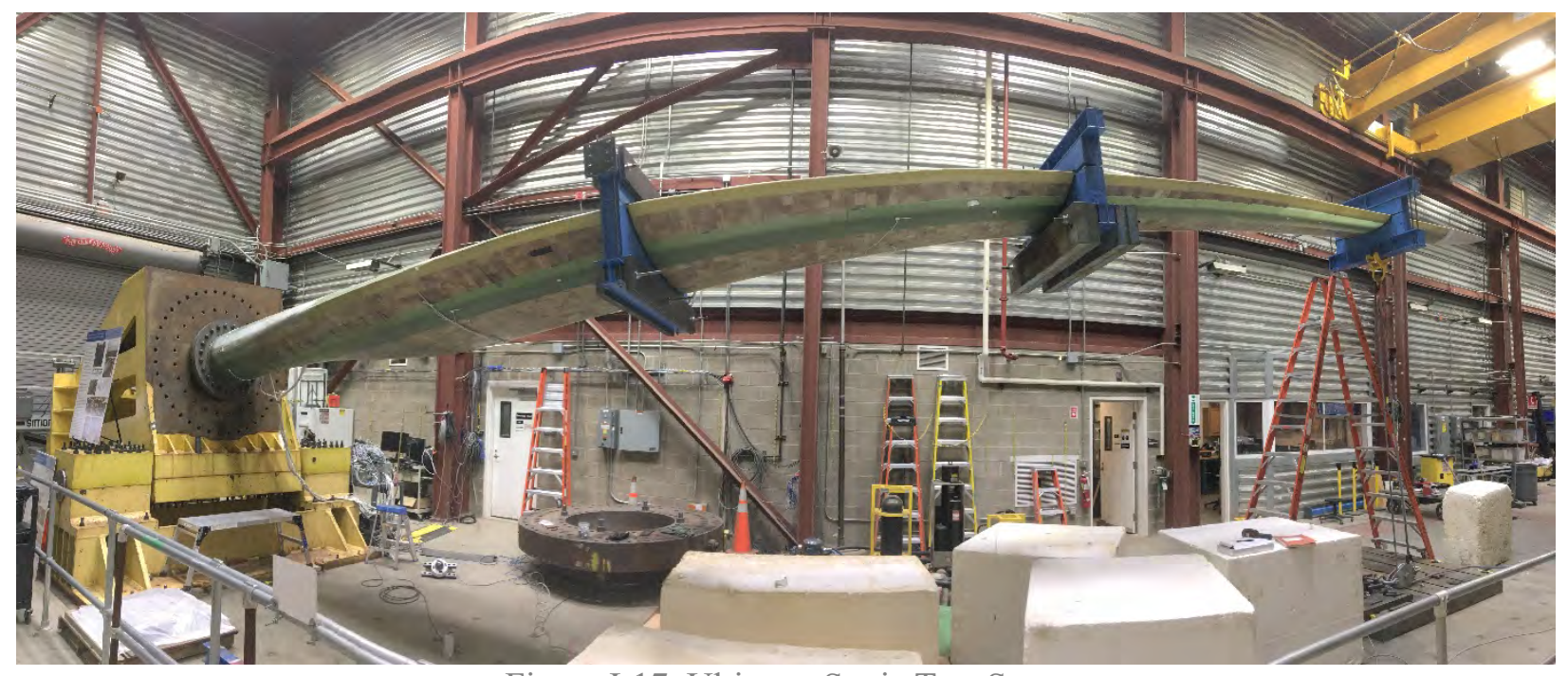

Figure I-17. Ultimate Static Test Setup 


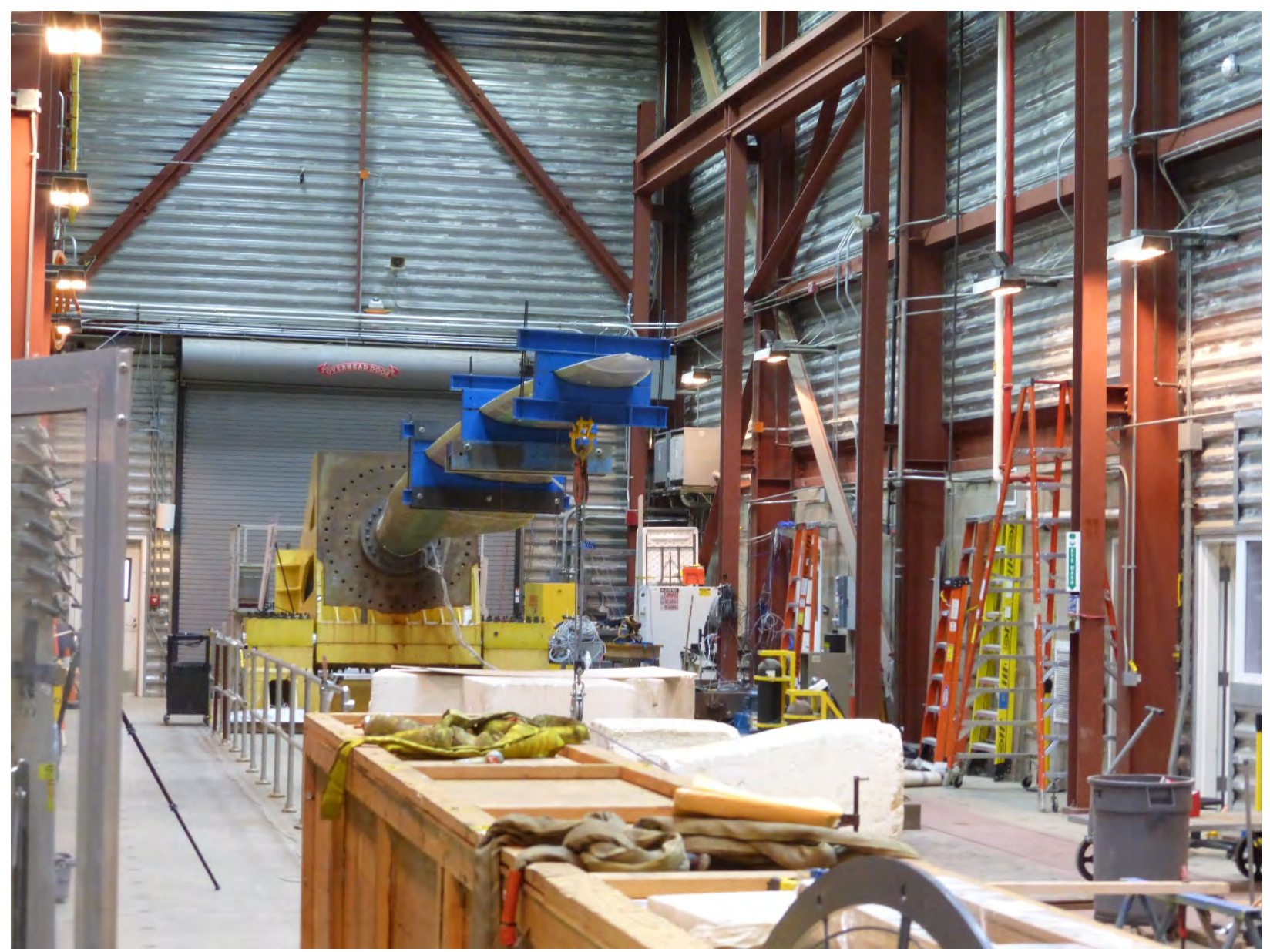

Figure I-18. Ultimate Static Test Near Tare Load 


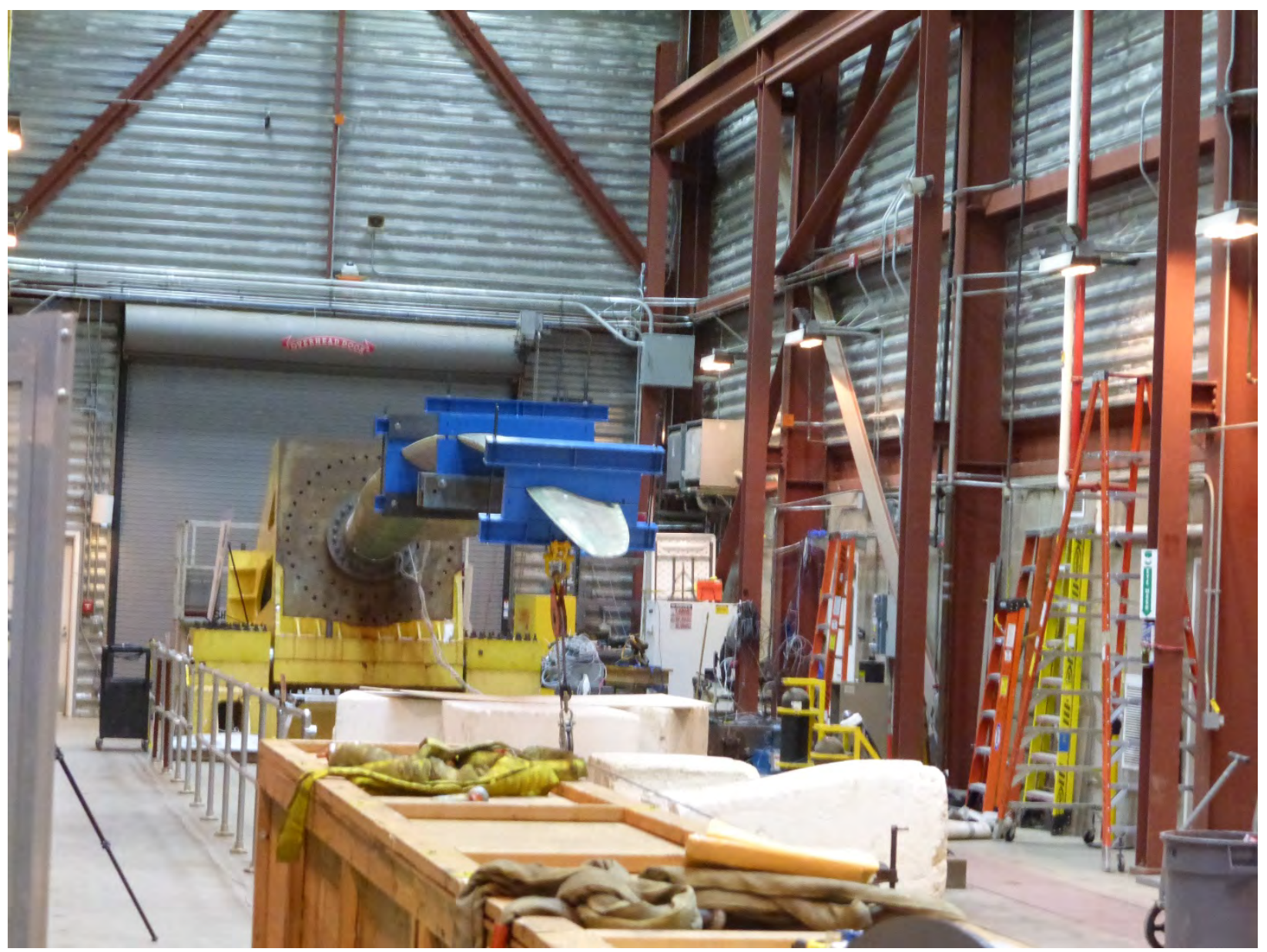

Figure I-19. Ultimate Static Test near failure load 


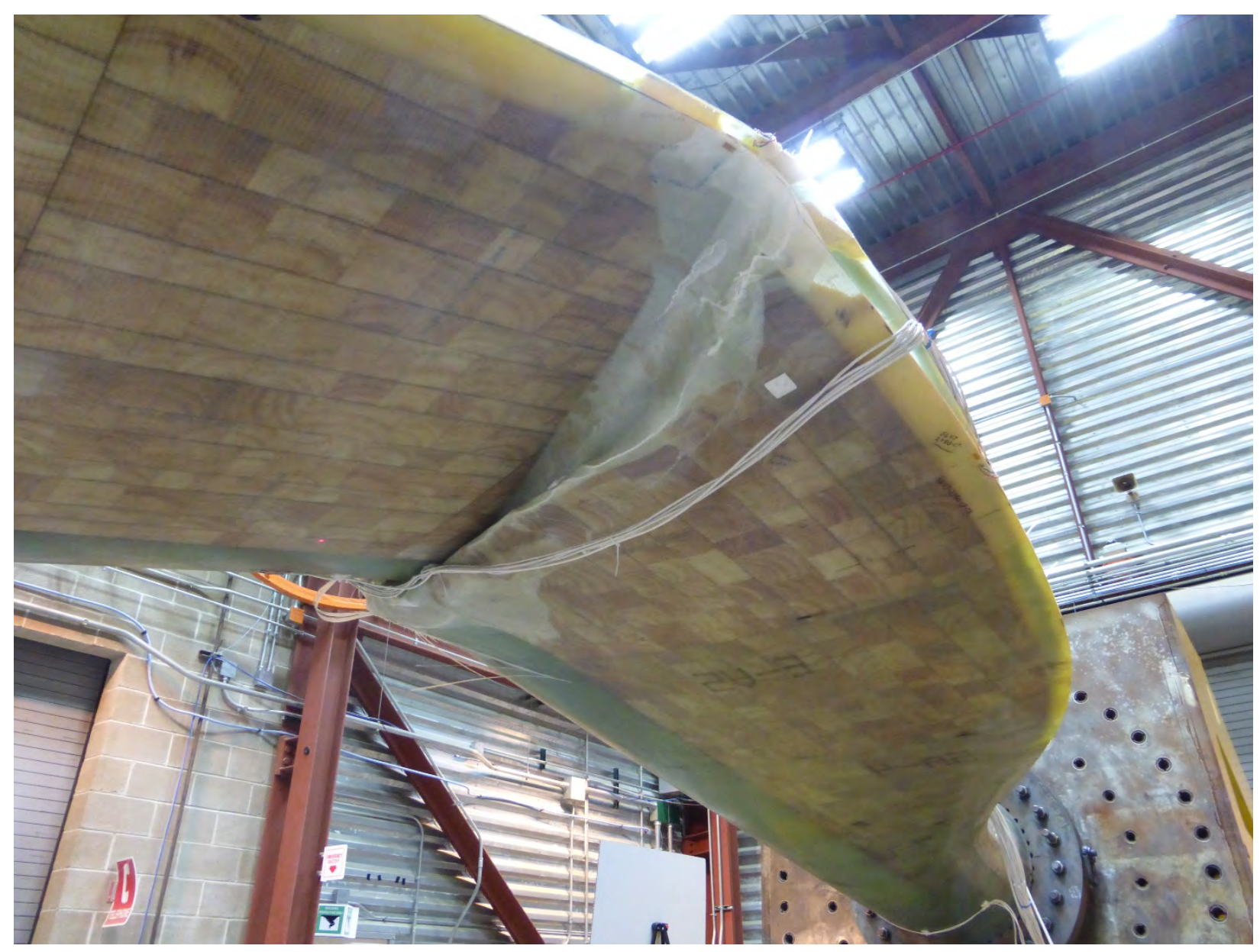

Figure I-20. Ultimate Static Test - blade after failure, LP side 


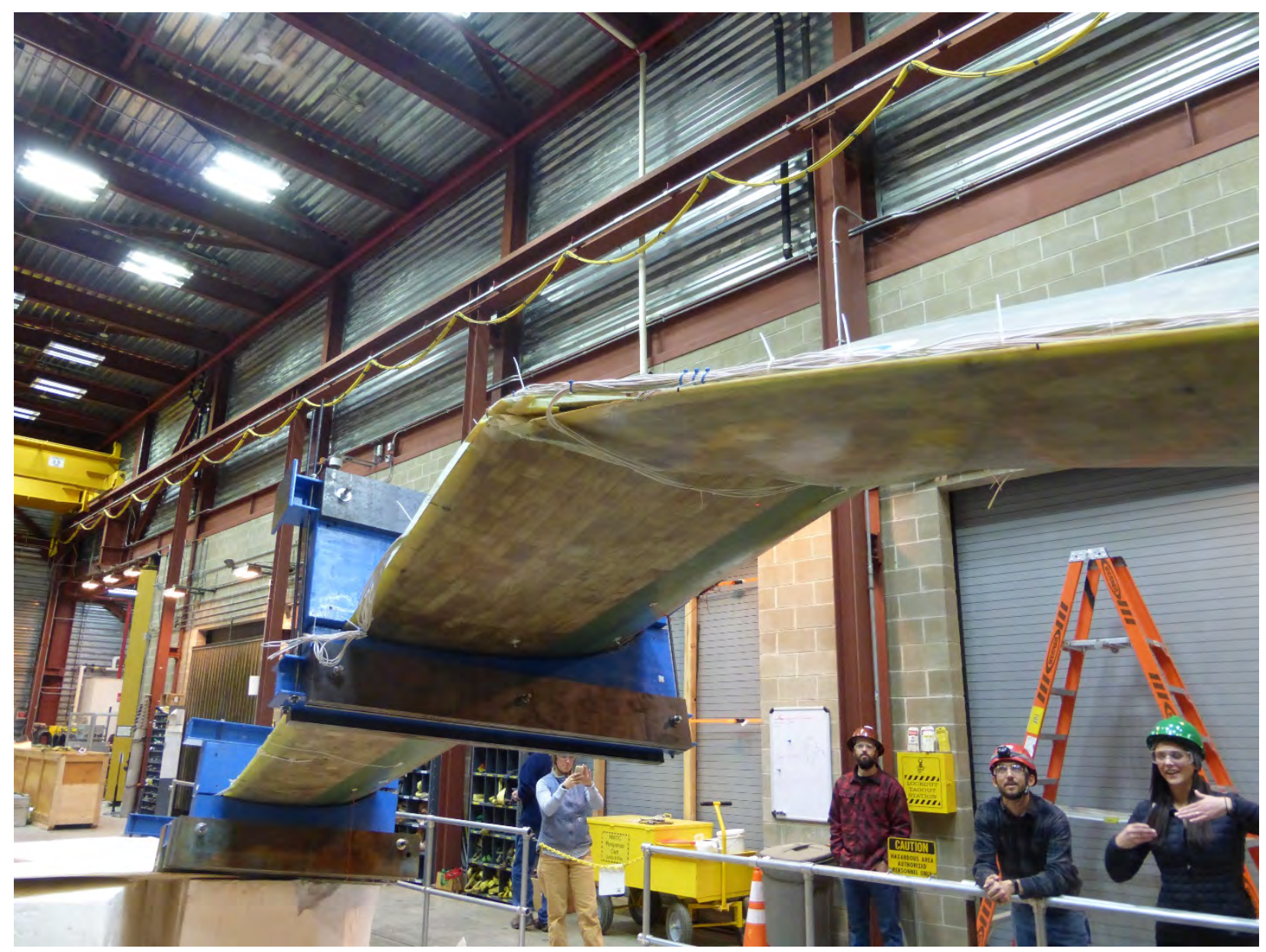

Figure I-21. Ultimate Static Test - blade after failure viewing LP from TE 


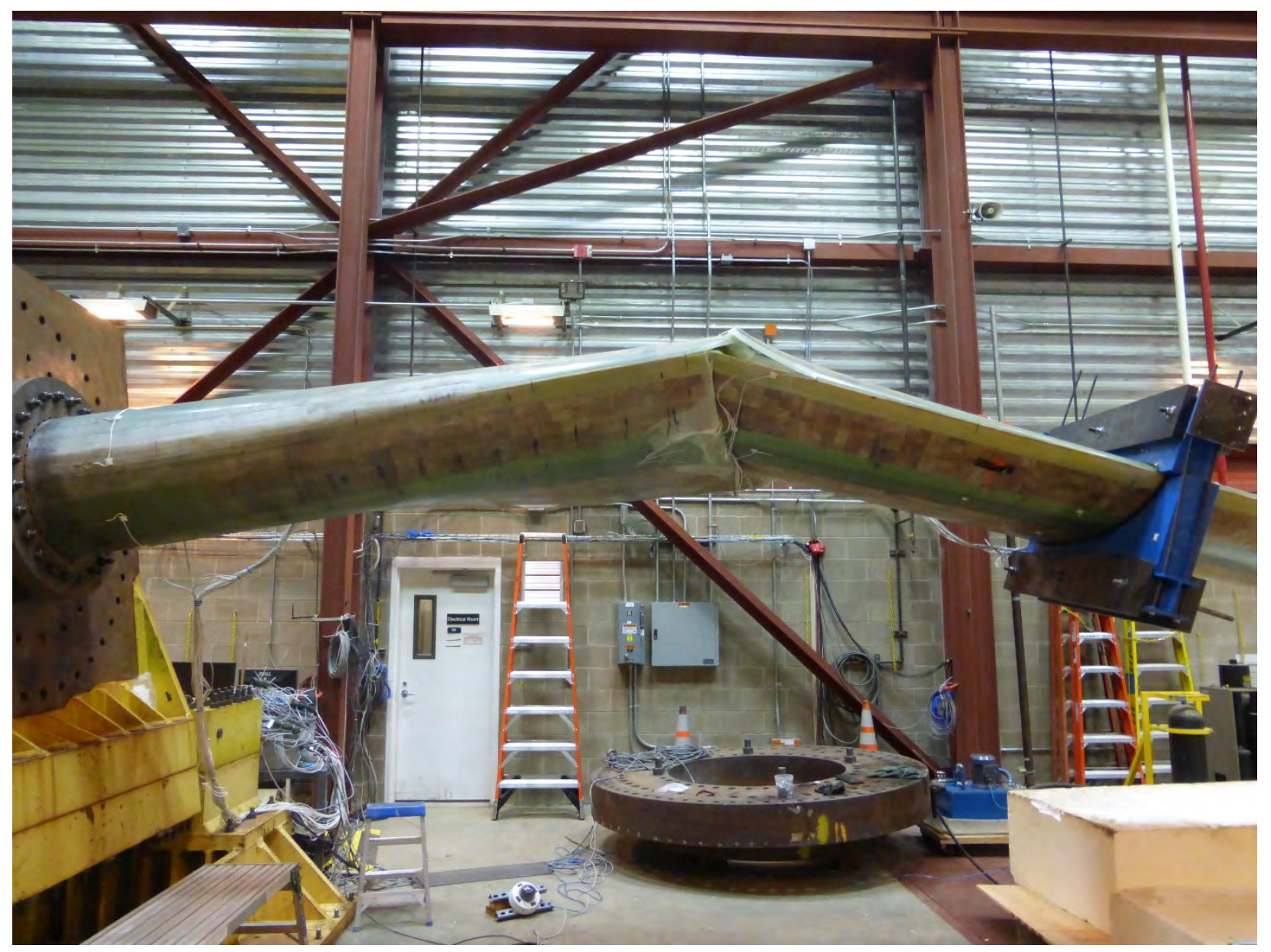

Figure I-22. Ultimate Static Test post failure from LE 


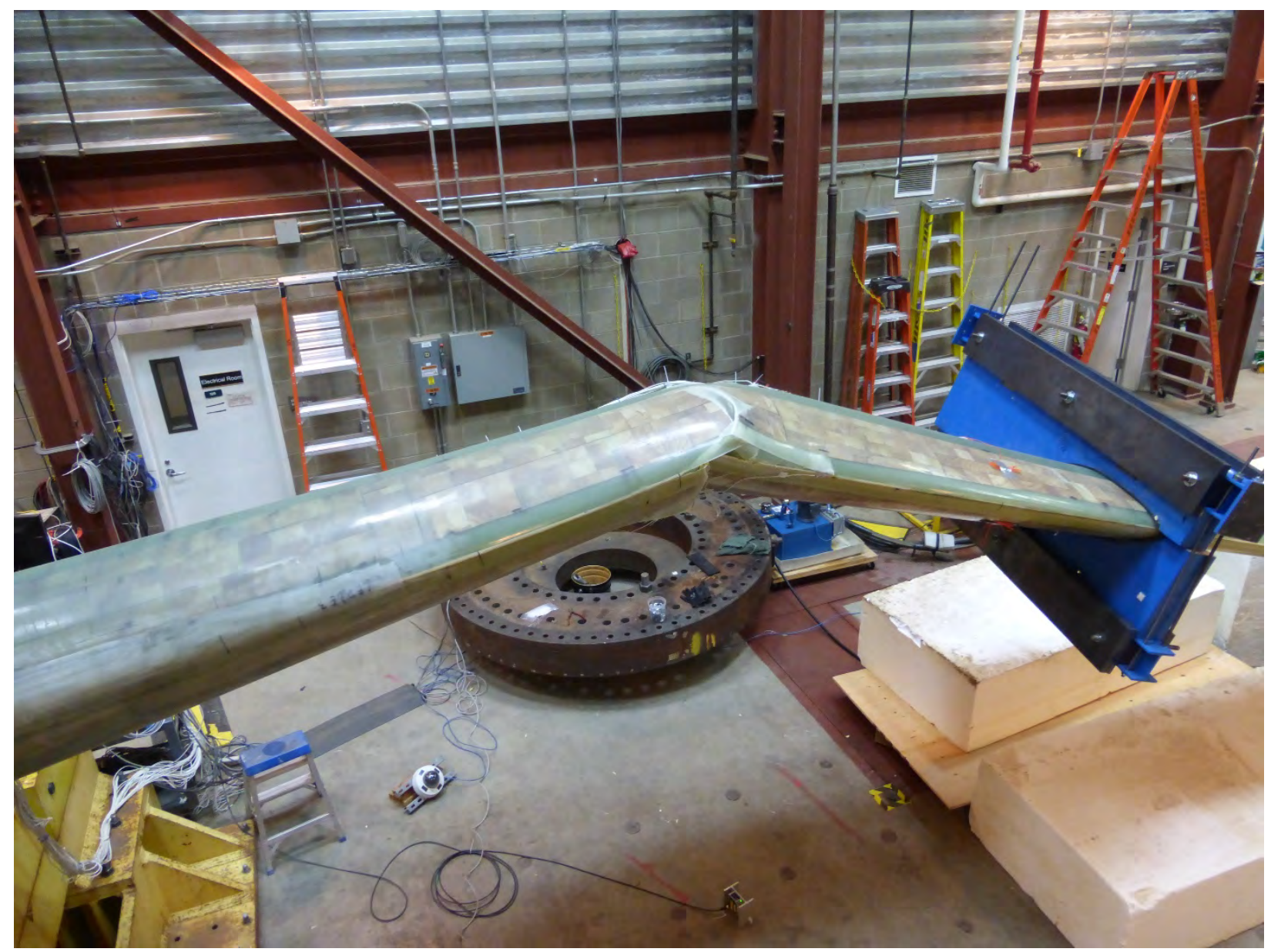

Figure I-23. Ultimate Static Test, HP side 